\title{
Design of MFI Type Aluminum- and Titanium-Containing Zeolites
}

\author{
Galina M. Kuz'micheva, Elena N. Domoroshchina *(D) and Galina V. Kravchenko
}

Citation: Kuz'micheva, G.M.; Domoroshchina, E.N.; Kravchenko, G.V. Design of MFI Type Aluminumand Titanium-Containing Zeolites. Crystals 2021, 11, 1451. https:// doi.org/10.3390/cryst11121451

Academic Editor: Eamor M. Woo

Received: 1 November 2021

Accepted: 19 November 2021

Published: 24 November 2021

Publisher's Note: MDPI stays neutral with regard to jurisdictional claims in published maps and institutional affiliations.

Copyright: (c) 2021 by the authors. Licensee MDPI, Basel, Switzerland. This article is an open access article distributed under the terms and conditions of the Creative Commons Attribution (CC BY) license (https:// creativecommons.org/licenses/by/ $4.0 /)$.
Institute of Physics and Technology, MIREA-Russian Technological University, Prospekt Vernadskogo 78, 119454 Moscow, Russia; galina_kuzmicheva@list.ru (G.M.K.); gal4onok-503@mail.ru (G.V.K.)

* Correspondence: elena_domoroshchina@mail.ru; Tel.: +7-495-246-0555 (ext. 434)

\begin{abstract}
HZSM-5 (MFI type) of composition $\left(\mathrm{H}_{\mathrm{x}}\right)\left[\mathrm{Al}^{3+}{ }_{\mathrm{x}} \mathrm{Si}_{12-\mathrm{x}} \mathrm{O}_{24}\right] \times w \mathrm{H}_{2} \mathrm{O}$ and nanocomposites NA/HZSM-5, NA:M/HZSM-5 (NA—nanoscale anatase; $M=\mathrm{V}, \mathrm{Ni}, \mathrm{Ag}$ ) with $\mathrm{Si} / \mathrm{Al}=12,25,40,300$ (sp.gr. Pnma or $P 21 / n ; \mathrm{z}=8$ ), as well as zeolites $\left[\left(\mathrm{Ti}^{4+}{ }_{\mathrm{x}} \mathrm{Si}_{12-\mathrm{x}} \mathrm{O}_{24}\right] \times w \mathrm{H}_{2} \mathrm{O}\right.$ (TS) with $\mathrm{Si} / \mathrm{Ti}=47,53$, 73.5 (sp.gr. Pnma) were studied by XRPD, XAS, FTIR-spectroscopy, BET, XPS, SEM, EDX, TPD, UVVIS-spectroscopy, UV-DRS, and chemiluminescence methods. The results obtained together with photocatalytic, adsorption, antimicrobial, catalytic properties were analyzed using crystallochemical concepts and literature data. It was shown that NA or NA:M introduction into HZSM-5 leads, respectively, to the photodegradation of $\mathrm{MeO}$ dye in the UV region or difenoconazole in the visible range, and contributes to the appearance in the dark of adsorption (almost complete extraction of $\mathrm{P}(\mathrm{V})$, $\mathrm{As}(\mathrm{V})$, and $\mathrm{Se}(\mathrm{V})$ from aquatic environment) and bacteriostatic properties in respect to Staphylococcus epidermidis, Bacillus antracoides, and Escherichia coli for NA:Ag/HZSM-5(40, 300). The presence of titanium ions in NA nanoparticles on the HZSM-5 surface improves the catalytic activity in ethanol and propane (the best performance for NA/HZSM-5(25) and NA/HZSM-5(40), respectively) conversion. Determination of the composition (surface and bulk) and structure (statistical and local) of TS zeolites together with the found correlations made it possible to propose new catalysts in the reactions of propane, ethanol, and allyl chloride conversion.
\end{abstract}

Keywords: zeolites; aluminosilicalites; titanosilicalites; nanoscale anatase; nanocomposites; preparation; crystal and local structure; $\left(\mathrm{H}^{1+}{ }_{(4-\mathrm{n}) \mathrm{x}}\right)\left[\mathrm{T}^{\mathrm{n}+}{ }_{\mathrm{x}} \mathrm{Si}^{4+}{ }_{12-\mathrm{x}} \mathrm{O}_{24}\right] \times w \mathrm{H}_{2} \mathrm{O}$; functional properties

\section{Introduction}

Zeolites are a large group of silicates that include several hundreds of compounds with a generalized composition formula where $M^{\mathrm{m}+}$ denotes inorganic or organic cations and $\left(T^{n+}{ }_{x} \mathrm{Si}_{1-\mathrm{x}}\right)$ denotes cations $T$ and $\mathrm{Si}$ with tetrahedral coordination arranged in one crystallographic site [1]. Currently, zeolites are considered to be tetrahedral oxide structures with the skeleton density no less than $20 \mathrm{~T}$ atoms per $1000 \AA$ irrespective of the material chemical composition [2].

Primary structural units in zeolites $\left(\mathrm{H}_{(4-\mathrm{n}) \mathrm{x}}\right)\left[T^{\mathrm{n}+}{ }_{\mathrm{x}} \mathrm{Si}^{4+}{ }_{12-\mathrm{x}} \mathrm{O}_{24}\right] \times w \mathrm{H}_{2} \mathrm{O}$ are tetrahedra (T) $\mathrm{SiO}_{4}$ and $\mathrm{TO}_{4}$ with typical average bond lengths $\mathrm{Si}-\mathrm{O}$ and $\mathrm{T}$-O $\sim 1.6 \AA$ and $\sim 1.7 \AA$, angles $\mathrm{O}-(\mathrm{Si}, \mathrm{T})-\mathrm{O}$ inside tetrahedra close to tetrahedral $\left(109.4^{\circ}\right)$, and angles $\mathrm{O}-(\mathrm{Si}, T) \mathrm{O}$ between tetrahedra varying in rather large limits from $\sim 135^{\circ}$ to $180^{\circ}$ (an average value is $\sim 154^{\circ}$ ) [3]. Tetrahedra are connected by vertexes of oxygen atoms with the formation of the three-dimensional skeleton (primary structure) with voids (cavities) of 4, 5, 6, 8, 10, and $12 \mathrm{~T}$ and sizes from 0.26 to $1.0 \mathrm{~nm}$, in which $X$, or neutral "guest" molecules are arranged, in particular, water. Just the general composition of the skeleton $\left[\left(T^{n+}{ }_{x} \mathrm{Si}_{1-x}\right) \mathrm{O}_{2}\right], T$ composition, and angles between $T$ are responsible for the configuration and sizes of cavities, and consequently, for the crystalline structure of zeolites. Undoubtedly, the structure is affected by the form (composition) and content of $M^{\mathrm{m}+}$ and $X$, but we speak about only protonated HZSM-5 zeolites in this work. According to the IUPAC nomenclature, they refer to MFI type. 
Functional properties of zeolites are determined by the skeleton composition and structure, the number and specific arrangement of active chemical centers in it, which are $\mathrm{V}_{\mathrm{Si}}{ }^{n \prime}$, or vacancies in the silicon site, $T_{\mathrm{Si}}{ }^{\mathrm{m} \prime}$ or $T_{\mathrm{Si}}{ }^{\mathrm{m}}$ depending on the formal charge of the $T$ ion in the $\mathrm{Si}^{4+}$ site, and charged ions compensating them, in particular, $\mathrm{OH}^{-}$and $\mathrm{H}^{+}$ groups in the case of protonated forms of zeolites.

Sizes, geometry, and connectivity of cavities, which determine the skeleton configuration, serve as no less important characteristics of zeolites. Geometry of combined voids is described in terms of the "channel system" (secondary structure), which can be linear or sinusoidal, and one-, two-, and three-dimensional depending on channel intersections in three dimensions [4]. Channel sizes, which are characterized by sizes of rings of $T$, specify limitations to the size and shape of molecules capable to "penetrate" into the zeolite crystalline structure.

All things described above (the skeleton, voids in the skeleton, and channels) refer to structural characteristics of zeolites, which predetermine their structure-dependent properties (for example, catalytic and molecular-sieve) [5-7]. However, zeolites possess unique textural characteristics (specific surface and its composition; porosity and pore size), which also affect the properties (absorption, diffusion, mechanical, etc.) and processes (heat-and-mass transfer) [8-11].

Zeolites HZSM-5 (MFI type) with the general composition $\left(\mathrm{H}_{(4-\mathrm{n}) \mathrm{x}}\right)\left[\mathrm{T}^{\mathrm{n}+}{ }_{\mathrm{x}} \mathrm{Si}^{4+}{ }_{12-\mathrm{x}} \mathrm{O}_{24}\right]$ $\times w \mathrm{H}_{2} \mathrm{O}$, which are considered in this work, form the large group of mesoporous and microporous crystalline silicates with micropore sizes from 0.2 to $2 \mathrm{~nm}$, and mesopores sizes from 2 to $50 \mathrm{~nm}$ and with large specific surface (up to $834.41 \mathrm{~m}^{2} / \mathrm{g}$ ) [12], which are distinguished by a broad spectrum of silicate module $\mathrm{Si} / \mathrm{T}$ and, from here, by variable properties, among other zeolites.

Aluminosilicalites $\left(\mathrm{H}^{1+} \mathrm{x}\right)\left[\mathrm{Al}^{3+}{ }_{\mathrm{x}} \mathrm{Si}^{4+}{ }_{12-\mathrm{x}} \mathrm{O}_{24}\right] \times w \mathrm{H}_{2} \mathrm{O}$ are used in acid-catalyzed reactions such as isomerization and alkylation of hydrocarbons [13], acylation of anisole $\left(\mathrm{C}_{7} \mathrm{H}_{8} \mathrm{O}\right)$ with a propionic anhydride $\left(\mathrm{C}_{6} \mathrm{H}_{10} \mathrm{O}_{3}\right)$ to obtain p-methoxypropiophenone $\left(\mathrm{C}_{10} \mathrm{H}_{12} \mathrm{O}_{2}\right)$ [14], transformation of ethanol $\left(\mathrm{C}_{2} \mathrm{H}_{5} \mathrm{OH}\right)$ into diethyl ether $\left(\left(\mathrm{C}_{2} \mathrm{H}_{5}\right)_{2} \mathrm{O}\right)[15,16]$ or ethylene $\left(\mathrm{C}_{2} \mathrm{H}_{4}\right)$ [16,17], propane $\left(\mathrm{C}_{3} \mathrm{H}_{8}\right)$ conversion with the formation of the main products propylene $\left(\mathrm{C}_{3} \mathrm{H}_{6}\right)$ and ethylene $\left(\mathrm{C}_{2} \mathrm{H}_{4}\right)$ [16], etc., and as adsorbents for recovery of methanol $\left(\mathrm{CH}_{3} \mathrm{OH}\right)[18]$, hydrocarbons (propane $\mathrm{C}_{3} \mathrm{H}_{8}$, propene $\mathrm{C}_{3} \mathrm{H}_{6}$, and n-butane $\mathrm{C}_{4} \mathrm{H}_{10}$ ) [19] from carbon monoxide (CO) [20] from the gas phase; and dyes (for example, methyl green [21]), which are used in the staining process (in textile industry) and contaminate wastewater [22] - from an aqueous medium.

Titanosilicalites of the composition $\left[\mathrm{Ti}^{4+}{ }_{\mathrm{x}} \mathrm{Si}^{4+}{ }_{12-\mathrm{x}} \mathrm{O}_{24}\right] \times w \mathrm{H}_{2} \mathrm{O}, \mathrm{MFI}$ type (they are denoted in publications as TS-1) are currently most efficient among heterogeneous catalysts of liquid-phase oxidation of various organic substrates by $\mathrm{H}_{2} \mathrm{O}_{2}$ aqueous solutions. TS-1 are used in such reactions as alkene epoxidation [23], cyclohexene conversion [24], oxidative desulfurization of dibenzothiophene (DBT) and 4,6-dimethyldibenzothiophene (4,6-DMDBT) [25], desulfurization [26], oxidation of 2,3,6-trimethylphenol [27], conversion of biomass to chemicals [28], cyclohexene epoxidation [29], oxidative hydration of ethylene [30], propylene epoxidation [31], propene epoxidation [32], allyl chloride epoxidation to epichlorohydrin, dehydrogenation of ethanol to acetaldehyde, propane conversion to propylene and ethylene [33], nitrous oxide decomposition [34], etc. Titanosilicalites can adsorb hydrocarbons in the presence of water [35], while ability of TS-1 to adsorb toluene and isopentane from the gas phase exceeds HZSM-5 aluminosilicate ( $\mathrm{Si} / \mathrm{Al}=30.5)$ [36].

The HZSM-5 zeolite matrix is promising as a stable inert "host" for various nanoobjects, in particular, nanodimensional oxides of titanium (IV) (NOT) with structures of anatase (NA) or rutile (general formula $\mathrm{TiO}_{2}$ ) or their mixtures, $\eta$-phase (E) with the structure derivative from the NA structure (superstructure to anatase; general formula $\left.\mathrm{TiO}_{2-\mathrm{x}} \times n \mathrm{H}_{2} \mathrm{O}\right)$.

The samples with nanoscale anatase (NA) are used as catalysts in "green" chemistry (for example, aldol condensation of furfurol with acetone) due to high oxidizing power, thermal and moisture resistance, and possibility of repeated use [37]. NOT samples are 
considered mainly as a support [38] or promoter [39] for nitrous oxide decomposition. Antimicrobial activity of the samples with NOT with respect to bacteria Staphylococcus aureus, Staphylococcus epidermidis, Escherichia coli, Bacillus antracoides, and fungi Candida albicans is known, which is determined by both physicochemical properties of NOT modifications (the samples with NA prepared by hydrolysis of $\mathrm{TiOSO}_{4} \times \mathrm{xH}_{2} \mathrm{SO}_{4} \times \mathrm{yH}_{2} \mathrm{O}$ are most active with respect to Staphylococcus aureus, Escherichia coli, and Candida albicans [40], while the samples with $\eta$-phase (E) are most active with respect to Staphylococcus aureus [41,42]), and by the nature of bacteria and fungi. Photocatalytic and adsorption properties of NOT are conditioned by surface hydroxyl groups with high reaction activity, which are selfgenerated when contacting with water, which leads to high adsorption ability to extract $\mathrm{Ni}$, $\mathrm{Co}, \mathrm{Sr}, \mathrm{Zn}, \mathrm{Ag}, \mathrm{Cu}, \mathrm{Hg}, \mathrm{Cd}, \mathrm{Tl}, \mathrm{Pb}, \mathrm{Mn}, \mathrm{Rb}, \mathrm{Cs}, \mathrm{Sn}, \mathrm{Cr}, \mathrm{Sb}, \mathrm{Al}, \mathrm{V}, \mathrm{As}, \mathrm{P}, \mathrm{Se}, \mathrm{Te}, \mathrm{Ta}, \mathrm{U}$, and transuranic ions, regardless of the oxidation state, from aqueous systems, see, e.g., [43], and photocatalytic activity in an ultraviolet part of sunlight [44].

Photocatalytic activity of NOT in a visible range is attained by modification either bulk (activator introduction into the phase composition-NOT:M), or surface (deposition of dyes, peroxide groupings, or $\mathrm{Au}, \mathrm{Ag}, \mathrm{Pt}, \mathrm{Ce}, \mathrm{V}$, and $\mathrm{Pt}$ ions on the surface of NOT particles, see, e.g., [45]. NOT:M demonstrate the photocatalytic activity in the visible region in the reaction of photodegradation of the cationic dye rhodamine $6 \mathrm{G}(\mathrm{R} 6 \mathrm{G})$ and the systemic triazole fungicide difenoconazole (in the $\mathrm{UV}$ and visible regions) $\left(\mathrm{NA}: \mathrm{V}^{4+}\right.$ and $\left.\mathrm{E}: \mathrm{V}^{4+}\right)$ [43], methylene blue (MB) in water (a mixture of anatase and rutile: $\left.\mathrm{V}^{4+}\right)[46]$ and NA: $\left.\mathrm{Cu}^{2+}[47]\right)$, methyl orange $(\mathrm{MeO})$ (a mixture of anatase and rutile: $\mathrm{V}^{4+}$ ) [48], isobutanol diluted in water $\left(\mathrm{NA}: \mathrm{V}^{4+}\right.$ ) [49], ibuprofen (Degussa P25: $\mathrm{Bi}^{3+}$ and Degussa P25: $\mathrm{Ni}^{2+}$; Degussa P25 is a mixture of nanodimensional anatase and rutile in a ration of $\sim 85 \%: 15 \%$ ) [50], dissolved organic matter represented by a model humic acid (Degussa P25: $\mathrm{Cu}^{2+}$ ) [51], and phenol in aqueous suspension (a mixture of anatase and rutile: $\mathrm{Al}^{3+}$ ) [52]. In addition, NOT:M manifest the higher adsorption ability for the extraction of $\mathrm{As}(\mathrm{V})$ anions from aqueous systems $\left(\mathrm{NA}: \mathrm{V}^{4+}\right)$ when compared with initial NOT:M [43] and antimicrobial activity in darkness against Staphylococcus aureus, Escherichia coli, and Bacillus anthracoides (NA: $\left.{ }^{4+}\right)$ [43] and Escherichia coli and Staphylococcus aureus under visible light irradiation (NA:Cu${ }^{2+}$ [53].

The formation of nanocomposites in the HZSM- 5 system (with various silicate moduli $\mathrm{Si} / \mathrm{Al}$ - - NOT (nominally pure or M-doped) can promote not only the enhancement of present properties of composites but the appearance of new ones due to the combination of separate parts into the united system.

Nanocomposites NA/HZSM-5 demonstrate:

- An increase in relative photocatalytic activity of NA under the effect of UV irradiation in an aqueous phase for the decomposition $\mathrm{MeO}$ (NA/HZSM-5(12, 40, 300) [54], NA/HZSM-5(2.3-2.5 wt.\% $\mathrm{Al}_{2} \mathrm{O}_{3}$ ) [55], NA:In/HZSM-5(50)) [56]), Brilliant Red X-3B (NA/HZSM-5(2.3-2.5 wt. $\% \mathrm{Al}_{2} \mathrm{O}_{3}$ ) [57], NA/HZSM-5 [58]), Acid Green 25 (NA/HZSM-5) [59]), Acid Red 1 (NA/HZSM-5 (Si/Al = 25) [60]), degradation of aqueous phenol and p-chlorophenol (Degussa P25/HZSM-5(30) [61]), enhancement of photocatalytic properties for (NA/HZSM-5(50) [62]) and NOx in the presence of water vapor (Degussa P25/HZSM-5(500, 200, 25) [63]), as well as photocatalytic properties under the effect of visible light in an aqueous medium with respect to $\mathrm{MeO}$ (NA:Fe/HZSM-5 $\left(\mathrm{Al}_{2} \mathrm{O}_{3} 2.3-2.5 \mathrm{wt} . \%\right)$ [64]) and triazole fungicide difenoxazole (NA:M/HZSM-5, $M=\mathrm{Ag}$, Ni, V [65]);

- Improvement of adsorption properties when compared with initial HZSM-5 and NA on the recovery (in darkness) of aqueous media of $\mathrm{P}(\mathrm{V})$ ions (NA/HZSM-5 $(12,40$, 300) [66], NA:M/HZSM-5(40) with $M=\mathrm{Ag}$, Ni, V [65]), As(V) (NA/HZSM-5(12, 40, 300) [67], NA:M/HZSM-5(40) with $M=\mathrm{Ag}, \mathrm{Ni}, \mathrm{V}$ [65]), and Se(V) (NA:M/HZSM-5(40) with $M=\mathrm{Ag}$, Ni, V [65]);

- Antimicrobial properties (in darkness) with respect to Staphylococcus epidermidis, Bacillus antracoides, and Escherichia coli (NA:Ag/HZSM-5(40) [65]); 
- Enhancement of catalytic properties relative to initial HZSM-5 in epoxidation reaction of allyl alcohol and allyl chloride (NA/HZSM-5(12, 40) [68]) and in the reactions of propane and liquid ethanol conversions (NA/HZSM-5(12, 25, 40 [16]).

The broadly variable chemical composition of HZSM- 5 zeolites ( $\mathrm{Si} / \mathrm{T}$ ), void sizes, the possibility of ordered arrangement of active centers, selectivity and directionality of the effect on chemical groups of molecules, and modification of nanocomposite formation (NA/HZSM-5) - all these factors make it possible to improve the properties of HZSM-5 in the specified direction and/or select zeolite necessary for the application. The knowledge of the composition and structure of HZSM-5, their textural and structural characteristics make it possible to establish the correlation bonds "composition-structure-properties" and "select" HZSM-5 with Si/T with optimal parameters for the specific application.

The goal of this work is to analyze the functional properties of $\left(\mathrm{H}^{1+}{ }_{(4-\mathrm{n}) \mathrm{x}}\right)\left[T^{\mathrm{n}+}{ }_{\mathrm{x}} \mathrm{Si}^{4+}{ }_{12-\mathrm{x}} \mathrm{O}_{24}\right] \times w \mathrm{H}_{2} \mathrm{O}(\mathrm{T}=\mathrm{Al}$, Ti) zeolites and their composites with nanoscale anatase (initial and activated with transition metal ions) and to establish their correlations with composition and structure to select possible application areas.

\section{Materials: General Information}

The objects of the study are HZSM- 5 zeolites $\left(\mathrm{H}_{(4-n) \times}\right)\left[T^{\mathrm{n}+}{ }_{\mathrm{x}} \mathrm{Si}^{4+}{ }_{12-\mathrm{x}} \mathrm{O}_{24}\right] \times w \mathrm{H}_{2} \mathrm{O}$ (hereinafter as $\mathrm{HZSM}$ ) with $\mathrm{Si} / \mathrm{Al}$ and $\mathrm{Si} / \mathrm{Ti}$ silicate modules, nanocomposites in the systems of $\operatorname{HZSM}(\mathrm{Si} / \mathrm{Al}=12,25,40,300)$-nanoscale anatase $(\mathrm{NA} / \mathrm{HZSM})$ and $\mathrm{HZSM}(\mathrm{Si} / \mathrm{Al}=40$, 300)—nanoscale anatase doped with transition metals (NA:M/HZSM, $M=\mathrm{Ag}, \mathrm{Ni}, \mathrm{V}$ ). Methods of HZSM zeolites, NA/HZSM, and NA:M/HZSM nanocomposites synthesis and characterization are systematized based on works $[16,33,34,54,65-76]$ and presented in Supplementary Materials.

\section{Results and Discussion}

\subsection{HZSM-5 Zeolites}

HZSM-5 (HZSM) zeolites with MFI-type structure according to the IUPAC nomenclature show two stable structures: a low temperature phase having monoclinic symmetry (sp. gr. $P 2_{1} / n ; 24 \mathrm{~T}$ ) and a high temperature one with orthorhombic symmetry (sp. gr. Pnma; $12 \mathrm{~T})$ [77-83].

The phase transition temperature mainly depends on several parameters: (i) the chemical composition of the framework (i.e., the nature and the amount of tetrahedrally incorporated atoms [84]); (ii) the density of internal defects (i.e., Si vacancies generating internal hydroxyl groups [84-89]); (iii) the nature and the equilibrium pressure of adsorbed organic molecules; (iv) the presence/absence (after burning) of the template [77]; and (v) as far as trivalent or with another formal charge heteroatoms are concerned, the chemical nature of the counterions [81].

HZSM zeolites (sp. gr. $P 22_{1} / n$ or sp. gr. Pnma; $\mathrm{z}=8$ ) have general compositions $\left[\mathrm{Si}^{4+}{ }_{12} \mathrm{O}_{24}\right] \times w \mathrm{H}_{2} \mathrm{O}$ (defect-free silicalite) or $\left\{\left(\mathrm{Si}^{4+}{ }_{12-\mathrm{x}} \square_{\mathrm{x}}\right)\left[\mathrm{O}_{24-\mathrm{x}}(\mathrm{OH})_{\mathrm{x}}\right]\right\} \times w \mathrm{H}_{2} \mathrm{O}$ (defective silicalite; $\square$-vacancies), as well as substituted silicalites of general compositions $\left.\left.\left(\mathrm{H}_{2 \mathrm{x}}\right)\left[T^{2+}{ }_{\mathrm{x}} \mathrm{Si}^{4+}{ }_{12-\mathrm{x}} \mathrm{O}_{24}\right] \times w \mathrm{H}_{2} \mathrm{O}\right),\left(\mathrm{H}_{\mathrm{x}}\right)\left[T^{3+}{ }_{\mathrm{x}} \mathrm{Si}^{4+}{ }_{12-\mathrm{x}} \mathrm{O}_{24}\right] \times w \mathrm{H}_{2} \mathrm{O}\right),\left[T^{4+}{ }_{\mathrm{x}} \mathrm{Si}^{4+}{ }_{12-\mathrm{x}} \mathrm{O}_{24}\right] \times$ $\left.\left.w \mathrm{H}_{2} \mathrm{O}\right),\left(T^{5+}{ }_{\mathrm{x}} \mathrm{Si}^{4+}{ }_{12-\mathrm{x}} \square_{\mathrm{x}}\right) \mathrm{O}_{24}\right) \times w \mathrm{H}_{2} \mathrm{O}$, according to the quasi-chemical reactions (reactions 1-4) [90]:

$$
0 \rightarrow V_{S i}^{\prime}+(\mathrm{OH})_{\mathrm{O}^{\prime}}^{\bullet}
$$

(reaction 1$)$

Vacancies in the silicon position and partial replacement of oxygen ions by $\mathrm{OH}$ groups for defective silicalite,

$$
\begin{gathered}
0 \rightarrow T_{S i}^{n \prime}+n H^{\bullet}\left(\text { for } T^{2+} \text { and } T^{3+}\right), \\
0 \rightarrow T_{S i}^{x}\left(\text { for } T^{4+}\right), \\
0 \rightarrow T_{S i}^{n \bullet}+V_{S i}^{n \prime}\left(\text { for } T^{5+}\right),
\end{gathered}
$$

(reaction 2) 
The tetrahedra ( $T$ ) in HZSM structure are connected by vertices of oxygen atoms to form a framework of two 5-membered, one 6-membered, and one 10-membered rings (Figure 1), forming a three-dimensional system of intersecting channels.

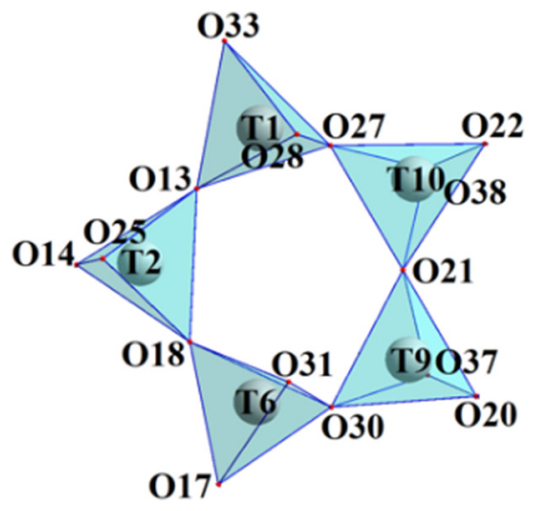

(a)

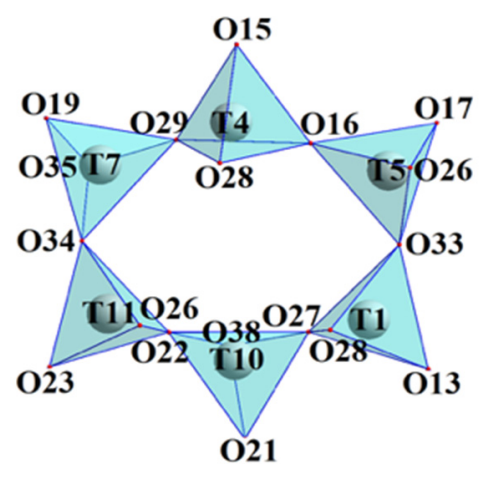

(c)

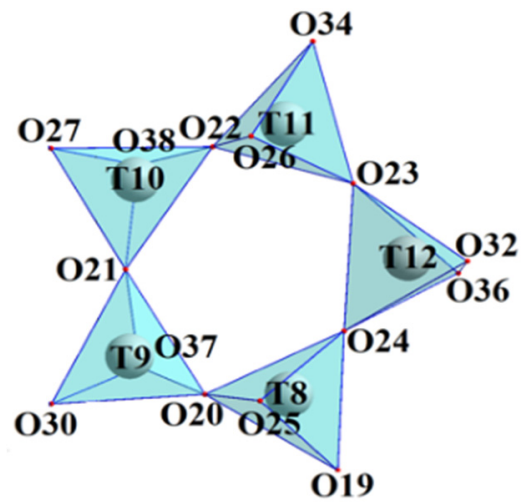

(b)

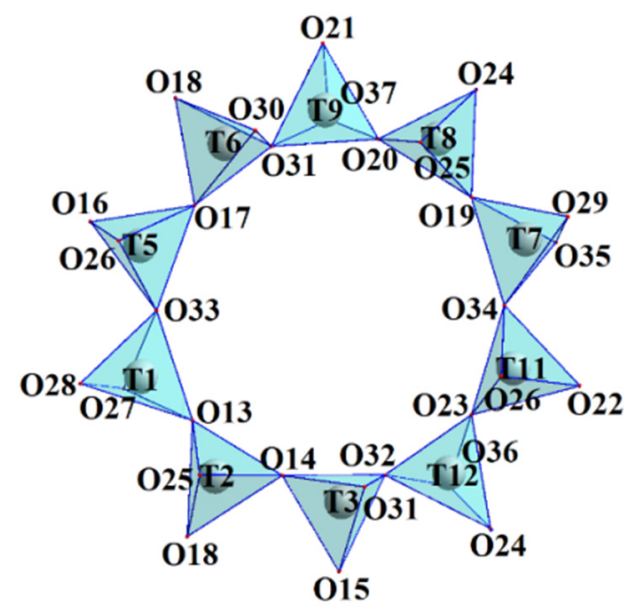

(d)

Figure 1. MFI-type zeolite tetrahedra rings (orthorhombic symmetry): 5-membered (a), 5-membered (b), 6-membered (c), 10-membered (d). The primary structure of HZSM zeolites (Adapted from [33]).

These rectilinear and sinusoidal channels, which can contain atoms, groups of atoms, molecules, water, etc., are located along the $\langle 010\rangle$ and $\langle 100\rangle$ directions, respectively, and are bounded by 10-membered tetrahedron rings [78].

In this case, the dimensions of the cavities (voids) of HZSM depend on the composition ( $\mathrm{Si} / T$ ratio) and on the symmetry: the maximum "effective" size of 10-membered rings cavities is $\sim 5.3$ to $5.4 \AA$ for the orthorhombic HZSM (sp. gr. Pnma) and $\sim 5.9$ to $6.0 \AA$ for monoclinic one (sp. gr. P2 $1 / n$ ) $[16,77]$.

Silicalite with monoclinic symmetry, as compared to orthorhombic, demonstrates higher values of $\mathrm{SiO}_{4}$ polyhedra distortion degree, average values of interplanar spacings $\left(\mathrm{d}_{\text {average }}{ }^{\mathrm{IV}} \AA\right)$ and sizes of cavities in the structure frame as well as minimum values of $\mathrm{Si}-\mathrm{O}-\mathrm{Si}$ angles connecting $\mathrm{SiO}_{4}$ tetrahedra (Figure 1), with a slight divergence of the O-Si-O angles inside the $\mathrm{SiO}_{4}$ tetrahedra $[78,91]$.

The properties of silicalites are determined by the presence of vacancies and their content in the framework. It was found that among the 12 tetrahedral sites in orthorhombic silicalite structure, the T2, T3, T6, T7, T9, T10, and T11 sites are less occupied (Table 1), i.e., the formation of vacancies in the silicon sites is observed [92]. 
Table 1. Defects in tetrahedral sites (marked with a plus) of orthorhombic structures: defect-free $\left[\mathrm{Si}^{4+}{ }_{12} \mathrm{O}_{24}\right] \times w \mathrm{H}_{2} \mathrm{O}$ and defective $\left\{\left(\mathrm{Si}^{4+}{ }_{12-\mathrm{x}} \square_{\mathrm{x}}\right)\left[\mathrm{O}_{24-\mathrm{x}}(\mathrm{OH})_{\mathrm{x}}\right]\right\} \times w \mathrm{H}_{2} \mathrm{O}$ ( $\square$-vacancies) silicalites.

\begin{tabular}{|c|c|c|c|c|c|c|c|c|c|c|c|c|}
\hline \multicolumn{13}{|c|}{ T Site } \\
\hline Sample & T1 & T2 & T3 & $\mathrm{T} 4$ & T5 & T6 & T7 & T8 & T9 & T10 & T11 & T12 \\
\hline Si-1 & & & & & & + & + & & & + & + & \\
\hline $\mathrm{Si}-2$ & & + & + & & & + & & & & & & \\
\hline Si-3 & & & & & & & & & + & + & & \\
\hline $\mathrm{Si}-4$ & & & & & & + & + & & & + & + & \\
\hline \multicolumn{13}{|c|}{$\begin{array}{l}\text { Note. Si-1 [89]—powder neutron diffraction (Rietveld method); silicalite deuteration }\left(\mathrm{D}_{2} \mathrm{O}\right) \text {, determination of the } \\
\text { sites occupancy (p) in the structure ( } \mathrm{p} \sim 0.75) \text {; } \mathrm{Si}-2 \text { [93]—powder } \mathrm{X} \text {-ray diffraction (diffractometer; Rietveld method; } \\
\text { the number of defective } \mathrm{Si} \text { atoms is } \sim 1.5 \text { per unit cell); solid-state }{ }^{29} \mathrm{Si} \text { NMR spectroscopy (the number of defective } \\
\mathrm{Si} \text { atoms is } \sim 1.6 \text { per unit cell); } \mathrm{Si}-3 \text { [91]—-single crystal X-ray diffraction (synchrotron, room temperature) and } \\
\text { NMR spectroscopy of defect-free silicalite: positions T9 and T10 are favorable for substitution; } \mathrm{Si}-4 \text { [94]—powder } \\
\text { neutron diffraction (Rietveld method); determination of } T \text { positions occupation degree; comparison with the } T \\
\text { sites fully occupied by the } \mathrm{Si} \text { atom. }\end{array}$} \\
\hline
\end{tabular}

It is believed [92] that it is in these sites that $T$ ions can be found in substituted silicalites of general compositions $\left[\left(\mathrm{Ti}^{4+}{ }_{\mathrm{x}} \mathrm{Si}^{4+}{ }_{12-\mathrm{x}}\right) \mathrm{O}_{24}\right]$ or $\left(\mathrm{H}^{1+}{ }_{\mathrm{x}}\right)\left[\mathrm{T}^{\mathrm{n}+}{ }_{\mathrm{x}} \mathrm{Si}^{4+}{ }_{12-\mathrm{x}} \mathrm{O}_{24}\right] \times w \mathrm{H}_{2} \mathrm{O}$.

$\mathrm{Si}$ atoms in $\left[\mathrm{SiO}_{2}\right] \times w \mathrm{H}_{2} \mathrm{O}$ structure $[89,93]$ occupy distorted tetrahedra, in which four oxygen atoms are located at distances $d \sim 1.56 \div \sim 1.63 \AA$. Based on the oxygen radius $(R \sim 1.35 \AA$ [94] $)$, the $T^{4+}$ ions, replacing $\mathrm{Si}^{4+}$ ions in $\left(\mathrm{H}^{1+}{ }_{(4-n) \times}\right)\left[T^{\mathrm{n}+}{ }_{x} \mathrm{Si}^{4+}{ }_{12-x} \mathrm{O}_{24}\right] \times w \mathrm{H}_{2} \mathrm{O}$, can have dimensions $r \sim 0.20 \div \sim 0.28 \AA\left(\mathrm{r}_{\mathrm{Si}}{ }^{\mathrm{IV}}=0.26 \AA ; \mathrm{r}^{\mathrm{IV}}\right.$ 一radius for coordination number $\mathrm{CN}=4$ [95]). Considering the size factor of isomorphic miscibility [96], namely, the ion size $(\mathrm{r}, \AA)$ and criterion:

$$
\Delta r, \%=\frac{r_{\max }-r_{S i}}{r_{s i}} \sim 15 \%,
$$

Wide substitution of $\mathrm{Si}^{4+}$ ions by $T^{\mathrm{n}+}$ ions with $r_{\max } \sim 0.30 \AA$ is possible with the formation of $\left(\mathrm{H}^{1+}{ }_{(4-\mathrm{n}) \mathrm{x}}\right)\left[\mathrm{T}^{\mathrm{n}+}{ }_{\mathrm{x}} \mathrm{Si}^{4+}{ }_{12-} \mathrm{O}_{24}\right] \times w \mathrm{H}_{2} \mathrm{O}$. Notwithstanding the conventionality of the above estimates, it can be expected that the limits of substitution of $\mathrm{Si}^{4+}$ ions by $\mathrm{T}^{\mathrm{n}+}$ ions will decrease in the row $\mathrm{Be}^{2+}(r=0.27 \AA)>\mathrm{V}^{5+}(r=0.36 \AA)>\mathrm{Ge}^{4+}(r=0.39 \AA) \sim \mathrm{Al}^{3+}$ $(r=0.39 \AA)>\mathrm{Cr}^{4+}(r=0.41 \AA)>\mathrm{Ti}^{4+}(r=0.42 \AA)>\mathrm{Ga}^{3+}(r=0.47 \AA)>\mathrm{Fe}^{3+}(r=0.49 \AA)>$ $\mathrm{Ni}^{2+}(r=0.55 \AA) \sim \mathrm{Sn}^{4+}(r=0.55 \AA)>\mathrm{Cu}^{2+}(r=0.57 \AA)>\mathrm{Co}^{2+}(r=0.58 \AA)>\mathrm{Zr}^{4+}(r=0.59 \AA)$ $>\mathrm{Zn}^{2+}(r=0.60 \AA)>\operatorname{In}^{3+}(r=0.62 \AA)>\mathrm{Mn}^{2+}(r=0.66 \AA)$. It is necessary to take into account the polarity of the substitution (an ion with a larger radius is more difficult to replace with ions of a smaller size, for example, $\mathrm{Si}^{4+}(r=0.26 \AA)$ with $\left.\mathrm{P}^{5+}(r=0.17 \AA)\right)$ and formal charges $(\mathrm{FC})$ of substituted $\left(\mathrm{Si}^{4+}\right.$ with $\left.\mathrm{FC}=4\right)$ and substitutional ions $\left(T^{\mathrm{n}+}\right)$ (an increase in the difference between FC sharply decreases the limits of components isomorphic miscibility) [96].

However, if we rely on the principle of G. Bokii [97]: "The apparent size of atoms depends on their relative number (the smaller the relative number of atoms, the smaller its apparent size)", then the fabrication of zeolites (in particular, HZSM) with partial replacement of $\mathrm{Si}^{4+}$ ions with larger ones $\left(T^{\mathrm{n}+}\right)$ in tetrahedra is quite likely. However, for $\mathrm{T}^{\mathrm{n}+}$ ions that are prone to octahedral coordination (for example, $\mathrm{Ti}^{4+}$ ions), there will be a tendency to transform the tetrahedron into an octahedron [98]. On the other hand, if the size of the $T$ ion is less than the specified limit (for example, $\mathrm{B}^{3+}$ with $r=0.11 \AA$ ), then the tendency to rearrange the tetrahedron into a trigonal pyramid and then into a triangle can be observed [98].

According to [96], using interatomic distances as the size factor $(d, \AA)$ for wide isomorphic substitutions:

$$
\Delta d, \%=\left(d_{\max }-d_{S i}\right) / d_{S i},
$$

$\Delta d<4-5 \%$ (at all temperatures) and $\Delta d<8-10 \%$ (>373 to $673 \mathrm{~K}$ ). According to [89,92,93], the $\mathrm{Si}^{4+}$-O interatomic distances are in the range $d_{S i} \sim 1.56 \div \sim 1.63 \AA$, then $d_{\max } \sim 1.7 \AA$ with $r_{\text {max }} \sim 0.35 \AA$ (at all temperatures) and $d_{\max } \sim 1.8 \AA$ with $r_{\max } \sim 0.45 \AA$ ( $>373$ to $673 \mathrm{~K}$ ). 
The sizes of $T^{\mathrm{n}+}$ ions substituting for $\mathrm{Si}^{4+}$ ions in HZSM framework affect the parameters and unit cell volumes. Figure 2 shows the relationship between the ionic radius of $T$ ions $\left(r_{\mathrm{T}}{ }^{\mathrm{IV}}, \AA\right)$ and the unit cell volume $\left(\mathrm{V}, \AA^{3}\right)$ of HZSM zeolites.

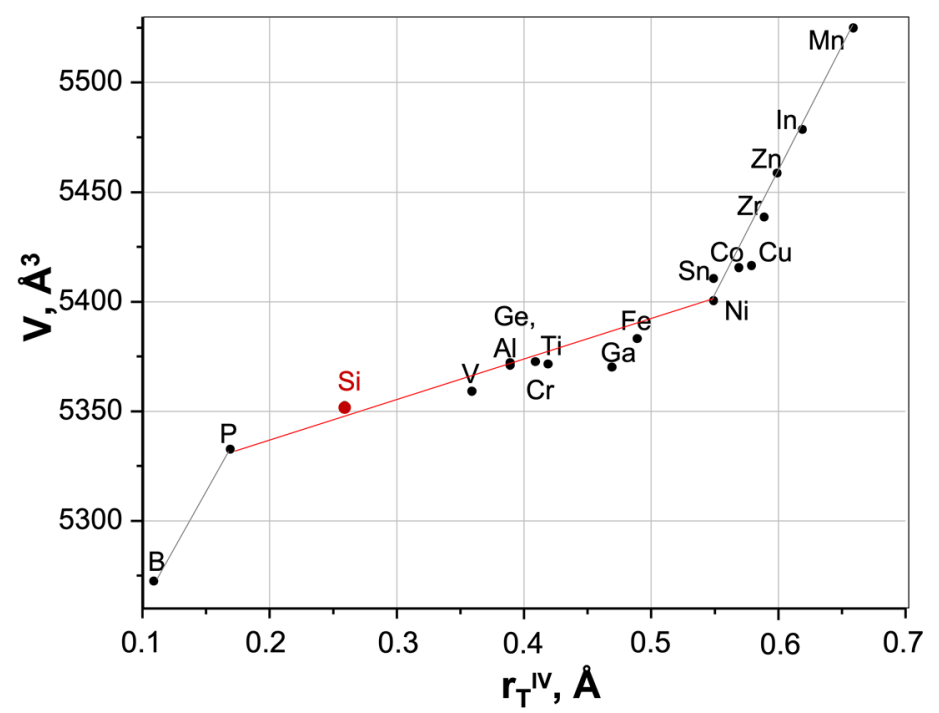

Figure 2. Relationship between the radius of $T$ ions $\left(r_{\mathrm{T}}{ }^{\mathrm{IV}}, \AA\right)$ and the unit cell volume $\left(\mathrm{V}, \AA^{3}\right)$ of (H)ZSM (Data from [98-113]).

With an increase in the substituting ion radius $(r, \AA)$, an increase in the unit cell volume $\left(\mathrm{V}, \AA^{3}\right)$ is observed (Figure 2), which can be described by two dependences:

$$
\begin{gathered}
V(r, \AA)=150.73 r+5309.30\left(\text { from } \mathrm{P}^{5+} \text { to } \mathrm{Ni}^{2+}\right), \\
V(r, \AA)=1121.63 r+4780.66\left(\text { from } \mathrm{Ni}^{2+} \text { to } \mathrm{Mn}^{2+}\right),
\end{gathered}
$$

Two fractures in Figure 2 can be caused either by a change in $T$ atom coordination (with a decrease or increase in coordination from tetrahedral, respectively, the first and second breaks), or by partial entry of $T$ atoms into the extraframework space.

For $(\mathrm{H}) \mathrm{ZSM}$ with $\mathrm{T}=\mathrm{Al}^{3+}(\mathrm{Si} / \mathrm{Al})$ and $\mathrm{Ti}^{4+}(\mathrm{Si} / \mathrm{Ti}$; TS) limited solid solutions should be expected at all temperatures: up to $\sim 5 \mathrm{wt} . \%$ and $\sim 4.2 \mathrm{wt} . \%$ of $\mathrm{Si}^{4+}$ ions can be replaced, respectively, by $\mathrm{Al}^{3+}$ [112] and $\mathrm{Ti}^{4+}$ [114] ions (it should be noted that these values differ in the literature). The solid solutions region can expand by an increase in the synthesis temperature, which usually promotes the isomorphic miscibility of components. Although there is no clear relation between the pressure and substitution of components, an increase in the degree of substitution can be observed with an increase in pressure in some cases. On the other hand, it is most promising to apply crystal chemical "assisting" rules (transition to another structure-directing agent with the larger size of the structural unit) and "mediator" (introduction of a buffer component), which can lead to an increase in limits of the isomorphic substitution [96]. The first rule was implemented by the authors of [115]: incorporation into (H)ZSM with Si/Ti (TS) up to $\sim 9 \mathrm{~mol} \%$ of Ti ( 9 Ti atoms/unit cell; Si/Ti 10) was attained by using tetrabutylorthotitanate (TBOT) instead of tetraethylorthotitanate (TEOT) in the synthesis. The second rule, which was applied by W. Fan et al. [116], allowed them by using the content of $\mathrm{Ti}^{4+}$ ions in TS with $\left(\mathrm{NH}_{4}\right)_{2} \mathrm{CO}_{3}$ as a crystallization-mediating agent by modifying the original dissolved titanium method. There are also other possibilities to vary the degree of substitution of $\mathrm{Si}^{4+}$ ions by $\mathrm{T}$ ions in the zeolite structure, for example, by varying the synthesis conditions (in particular, $\mathrm{pH}$ ) or/and the type of treatment of the reaction mixture (microwave, ultrasonic, etc.).

Despite numerous publications devoted to the experimental and theoretical determination of an actual composition of $\left[\mathrm{Ti}^{4+}{ }_{\mathrm{x}} \mathrm{Si}^{4+}{ }_{12-\mathrm{x}} \mathrm{O}_{24}\right] \times w \mathrm{H}_{2} \mathrm{O}$ or $\left(\mathrm{H}_{\mathrm{x}}\right)\left[\mathrm{Al}^{3+}{ }_{\mathrm{x}} \mathrm{Si}^{4+}{ }_{12-} \mathrm{O}_{24}\right] \times$ 
$w \mathrm{H}_{2} \mathrm{O}$ allowing for the defect character of silicon sites, the number of $\mathrm{OH}$ groups and water, the content and distribution of $T$ ions over crystal structure sites and their coordination by various techniques including powder $\mathrm{X}$-ray (a diffractometer and synchrotron) and neutron diffraction, FTIR, Raman, and UV-Vis spectroscopy, XAFS, computer modeling, etc., (see, e.g., $[94,114,117,118]$ and references in these works), the content and the location of the $T$ ions in the HZSM structure remains the subject of considerable debate.

The main (initial) method for studying zeolites (as well as other objects) is diffraction (in particular, the most accessible X-ray method using laboratory diffractometers) with all its techniques. However, the full-profile method application in the scope of the X-ray experiment (X-ray and X-ray synchrotron radiation) to determine the silicate modulus $\mathrm{Si} / \mathrm{T}$ with the $T$ ions placement at the structural sites is not an easy task. This is due to the small number of introduced $T$ ions, the large number of cationic and oxygen sites (for the sp. gr. Pnma, respectively, 12 and 24 and for the sp. gr. $P 2_{1} / n 24$ and 48 ), the overwhelming majority of which are common. For each atom, it is necessary to refine the coordinates and atomic displacement, and for cations (preferably for oxygen as well), the occupancy of the sites is also added, which introduces additional difficulties due to a correlation between atomic displacements and occupancy of sites. One should not forget about the difficulty of determining the real coordinates of silicon and oxygen atoms ("light" atoms) and the proximity of $\mathrm{Si}$ and $\mathrm{Al}$ form factors (the $\mathrm{X}$-ray experiment). In many cases, the aluminum atoms content is determined by chemical or elemental analysis, and their distribution over the structural sites by calculation methods (Table 2).

Table 2. Aluminum atoms distribution (* possible presence) over tetrahedral positions (marked with "+") of orthorhombic structures.

\begin{tabular}{|c|c|c|c|c|c|c|c|c|c|c|c|c|}
\hline \multicolumn{13}{|c|}{ T site } \\
\hline Sample & T1 & T2 & T3 & $\mathrm{T} 4$ & T5 & T6 & $\mathrm{T} 7$ & $\mathrm{~T} 8$ & T9 & T10 & T11 & T12 \\
\hline Al-1 & & & & & & + & & & + & & & + \\
\hline Al-2 & & & & + & & & + & + & + & & & \\
\hline Al-3 & & & & + & & + & & + & & & & \\
\hline $\mathrm{Al}-4$ & & + & & & & & & & & & + & \\
\hline Al-5 & + & & & * & & & & & & & & \\
\hline Al-6 & + & & + & & + & & + & & & & & \\
\hline Al-7 & + & + & & & + & & & & + & & & + \\
\hline Al-8 & & & $*$ & & & & & & & & * & \\
\hline Al-9 & & + & & & & & & & & & & + \\
\hline \multicolumn{13}{|c|}{ 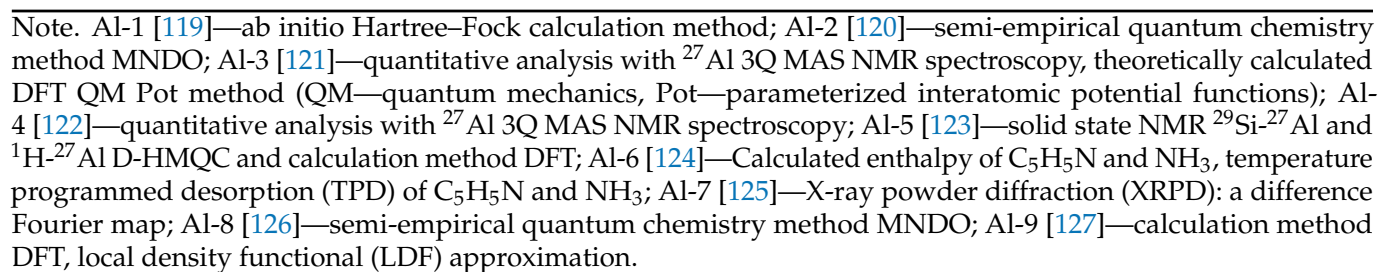 } \\
\hline
\end{tabular}

Comparison of data from Tables 1 and 2 indicates the presence of $\mathrm{Al}^{3+}$ ions both in defective tetrahedral sites of silicalite (T2, T3, T6, T7, and T9) (Table 1) and in others that were not identified as defective ( $\mathrm{T} 1, \mathrm{~T} 4, \mathrm{~T} 5, \mathrm{~T} 8$, and $\mathrm{T} 12)$ (Table 1 ). This evidences that there are currently no reliable methods for determining the structural sites of aluminum atoms in HZSM zeolites.

In their turn, structural characteristics of zeolites, the majority of which are a real composition, coordination, and distribution of atoms over structural sites, depend on the method and conditions of their fabrication, which is important for the directed synthesis of objects with required parameters. 
3.1.1. Aluminosilicalites $\left(\mathrm{H}_{\mathrm{x}}\right)\left[\mathrm{Al}^{3+}{ }_{\mathrm{x}} \mathrm{Si}^{4+}{ }_{12-\mathrm{x}} \mathrm{O}_{24}\right] \times w \mathrm{H}_{2} \mathrm{O}$ and Composites $\mathrm{NA} /\left(\mathrm{H}_{\mathrm{x}}\right)\left[\mathrm{Al}^{3+}{ }_{\mathrm{x}} \mathrm{Si}^{4+}{ }_{12-\mathrm{x}} \mathrm{O}_{24}\right] \times w \mathrm{H}_{2} \mathrm{O}$

3.1.1.1. Composition and Structure

The full-profile Rietveld method (Section S2.1) was used to determine the symmetry of HZSM aluminosilicates (for $\mathrm{Si} / \mathrm{Al}=12$ and 25 the symmetry is orthorhombic, for $\mathrm{Si} / \mathrm{Al}=40$ and 300-monoclinic) and NA/HZSM composites (Method 1a; see Section S1) as well as their unit cell parameters $(\mathrm{Si} / \mathrm{Al}=12,40,300)$ (Table 3$)$.

Table 3. Crystallographic parameters of $\operatorname{HZSM}(12,40,300)$ and NA/HZSM $(12,40,300)$.

\begin{tabular}{|c|c|c|c|c|c|c|}
\hline \multirow{2}{*}{ Characteristics } & $\operatorname{HZSM}(12) *$ & NA/HZSM (12) * & HZSM (40) & NA/HZSM (40) & HZSM (300) & NA/HZSM (300) \\
\hline & \multicolumn{2}{|c|}{ Pnma } & \multicolumn{4}{|c|}{$P 2_{1} / n$} \\
\hline$a, \AA$ & $20.1421(17)$ & 20.1085 (19) & $20.1221(16)$ & 20.1201 (19) & $20.1166(15)$ & 20.1208 (19) \\
\hline$b, \AA$ & $19.9402(18)$ & $19.9502(18)$ & 19.9109 (15) & $19.9097(18)$ & $19.8834(15)$ & $19.8938(17)$ \\
\hline$c, \AA$ & $13.4464(14)$ & $13.4494(15)$ & $13.3966(12)$ & $13.3944(14)$ & $13.3740(11)$ & $13.3832(15)$ \\
\hline$\alpha^{\circ}$ & - & - & $90.416(15)$ & $90.422(16)$ & $90.664(14)$ & $90.546(16)$ \\
\hline$V, \AA^{3}$ & $5400(1)$ & $5396(1)$ & $5367(1)$ & $5366(1)$ & $5350(1)$ & $5357(1)$ \\
\hline $\mathrm{B}_{\text {iso }}(T)$ & $1.10(1)$ & $1.43(2)$ & $0.23(1)$ & $0.18(1)$ & $0.37(1)$ & $0.63(2)$ \\
\hline $\mathrm{B}_{\text {iso }}(\mathrm{O})$ & $2.02(1)$ & $2.36(2)$ & $0.72(1)$ & $0.78(1)$ & $0.21(1)$ & $1.10(2)$ \\
\hline $\begin{array}{c}2 \theta_{\min }-2 \theta_{\max }, \Delta 2 \theta \\
\left({ }^{\circ}\right)\end{array}$ & $1.000-21.200,0.003$ & $1.000-21.200,0.003$ & $1.000-21.200,0.003$ & $1.000-21.200,0.003$ & $1.000-21.200,0.003$ & $1.000-21.200,0.003$ \\
\hline$\chi^{2} / R_{w p} / R_{\exp }$ & $9.141 / 0.047 / 0.020$ & $10.638 / 0.044 / 0.017$ & $13.048 / 0.053 / 0.018$ & $11.720 / 0.045 / 0.016$ & $57.357 / 0.075 / 0.013$ & $22.216 / 0.0495 / 0.014$ \\
\hline $\begin{array}{l}\text { Number of water } \\
\text { molecules per unit } \\
\text { cell }\end{array}$ & $36(1)$ & $42(1)$ & $10(1)$ & $11(1)$ & $6(1)$ & $5(1)$ \\
\hline
\end{tabular}

* impurity phase-zeolite MOR 7\%.

Using the found volumes of $\operatorname{HZSM}(12,40$, and 300) unit cells (Table 3$)$ and the known literature data (Figure 3), these zeolites contain, respectively, $\sim 10, \sim 1.0$, and $<1.0 \mathrm{Al}$ atoms per unit cell.

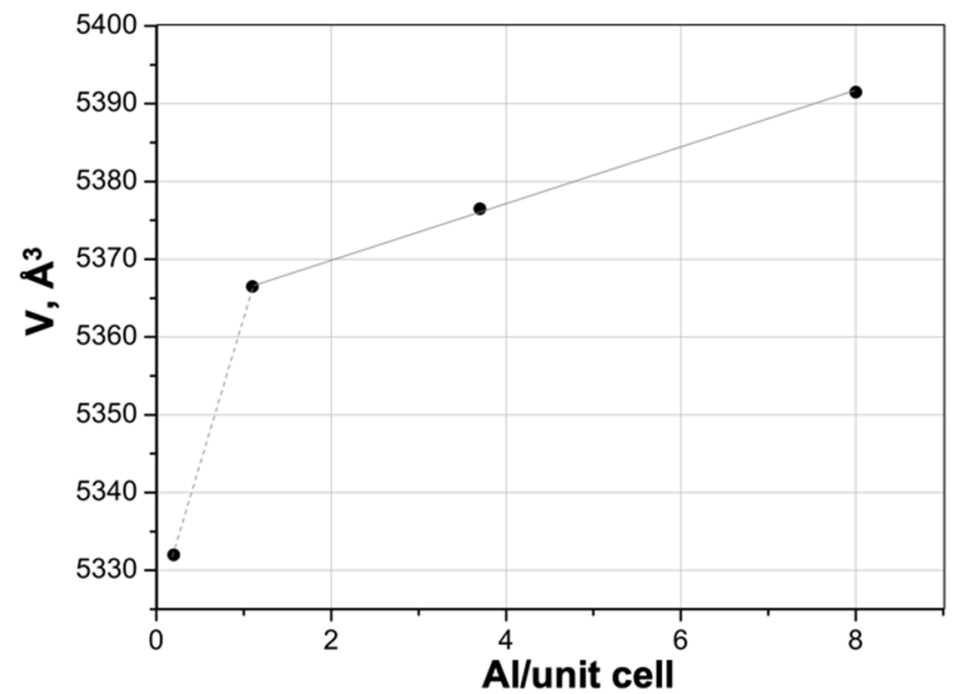

Figure 3. Relationship between the number of $\mathrm{Al}$ atoms per unit cell and the unit cell volume $\left(\mathrm{V}, \AA^{3}\right)$ in aluminosilicalites (data from $[77,78,128,129]$ ).

Calculation results of $\mathrm{Al} w \mathrm{wt} . \%$ based on the aluminosilicalites composition $\left(\mathrm{H}^{1+}{ }_{(4-\mathrm{n}) \times}\right)\left[T^{\mathrm{n}+}{ }_{\mathrm{x}} \mathrm{Si}^{4+}{ }_{12-\mathrm{x}} \mathrm{O}_{24}\right] \times w \mathrm{H}_{2} \mathrm{O}$ and the above mentioned amount of $\mathrm{Al}$ atoms per unit cell showed that $\mathrm{HZSM}$ with $\mathrm{Si} / \mathrm{Al}=12,40$, and 300 contain $\sim 4.6 \mathrm{wt} . \%, \sim 0.47 \mathrm{wt} . \%$, and $<0.47 \mathrm{wt} . \% \mathrm{Al}$, respectively. It qualitatively coincides with Table S1 data. 
The relationship between HZSM Si/Al value and unit cell volume can be described by linear dependences (Equation (5) ( $\mathrm{Si} / \mathrm{Al}=12,25,40$, Figure $4 \mathrm{~b}$ ) and Equation (6) $(\mathrm{Si} / \mathrm{Al}=40,300$, Figure $4 \mathrm{a})$.

$$
\begin{gathered}
V(x)=5412.1-1.17(6)(S i / A l), \\
V(x)=5369.6-0.07(S i / A l),
\end{gathered}
$$

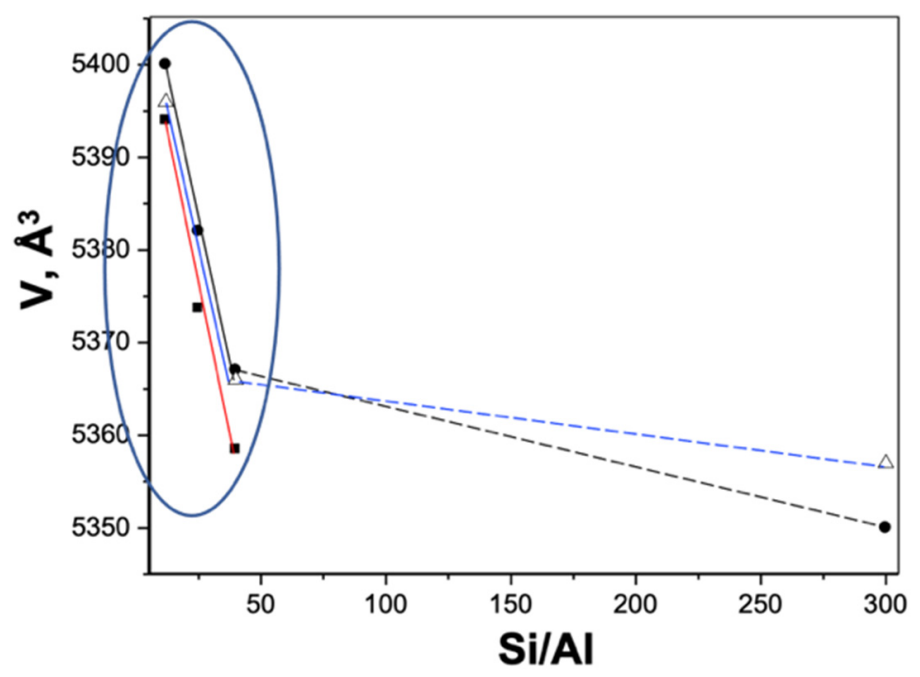

(a)

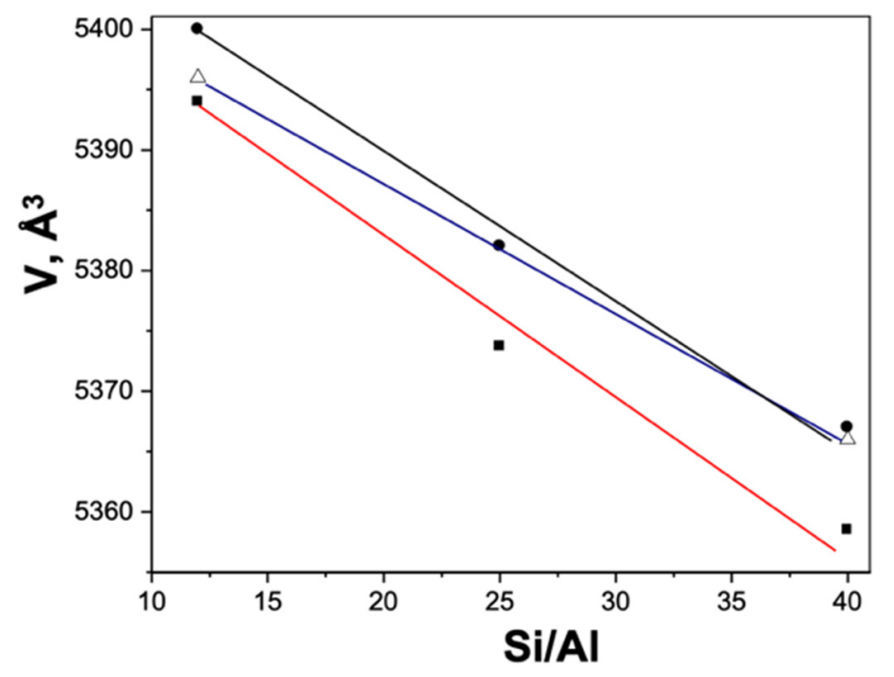

(b)

Figure 4. Relationship between HZSM and NA/HZSM silicate module ( $\mathrm{Si} / \mathrm{Al})$ and unit cell volume $\left(\mathrm{V}, \AA^{3}\right): \bullet-\mathrm{HZSM}$ and $\triangle$-NA/HZSM (Method 1a) according to data from the ESRF synchrotron; $\mathbf{\square}-\mathrm{HZSM}$ according to data from Kurchatov Synchrotron Radiation Source: $\mathrm{Si} / \mathrm{Al}=12,40$ and 300 (a), Si / Al = 12 and 40 (b).

Figure 4 shows a decrease in the unit cell volume of HZSM zeolites and NA/HZSM composites with an increase in the silicate modulus ( $\mathrm{Si} / \mathrm{Al}$ according to the chemical analysis of HZSM; Table S1), which seems to be logical due to the ratio of the ionic radii of $\mathrm{Si}^{4+}$ $\left(\mathrm{r}_{\mathrm{Si}}{ }^{\mathrm{IV}}=0.26 \AA\right)$ and $\mathrm{Al}^{3+}\left(\mathrm{r}_{\mathrm{Al}}{ }^{3+}=0.39 \AA\right)$ with $\mathrm{CN}=4$ [95]. Note that the unit cell parameters and the cell volume of the same sample can be different depending on the diffraction pattern obtaining conditions (Figure 4). The same reason causes a discrepancy between the composition calculated according to Figure 3 and the experimentally determined one.

Well distinguishable amorphous region in angle range $\sim 6$ to $7^{\circ}$ over $2 \theta(d \sim 13.38 \AA)$ (Figure $5 \mathrm{a}-\mathrm{c}$ ), which is responsible for silicon-containing oxygenous formations (more and less, respectively, in NA/HZSM with $\mathrm{Si} / \mathrm{Al}=12$ and $\mathrm{Si} / \mathrm{Al}=40$ ) is present in X-ray diffraction patterns of all samples. The coordinates of all atoms (initial model from [77]) and the total averaged atomic displacements of $\mathrm{Si} / \mathrm{Al}$ and $\mathrm{O}$ in the isotropic approximation were refined, and the structural localization and oxygen content in water molecules were determined. The number of water molecules per unit cell decreases in the row: NA/HZSM(12) $>\operatorname{HZSM}(12)>\mathrm{NA} / \mathrm{HZSM}(40)>\operatorname{HZSM}(40)>\operatorname{HZSM}(300)>\mathrm{NA} / \mathrm{HZSM}(300)$ (Table 3). 


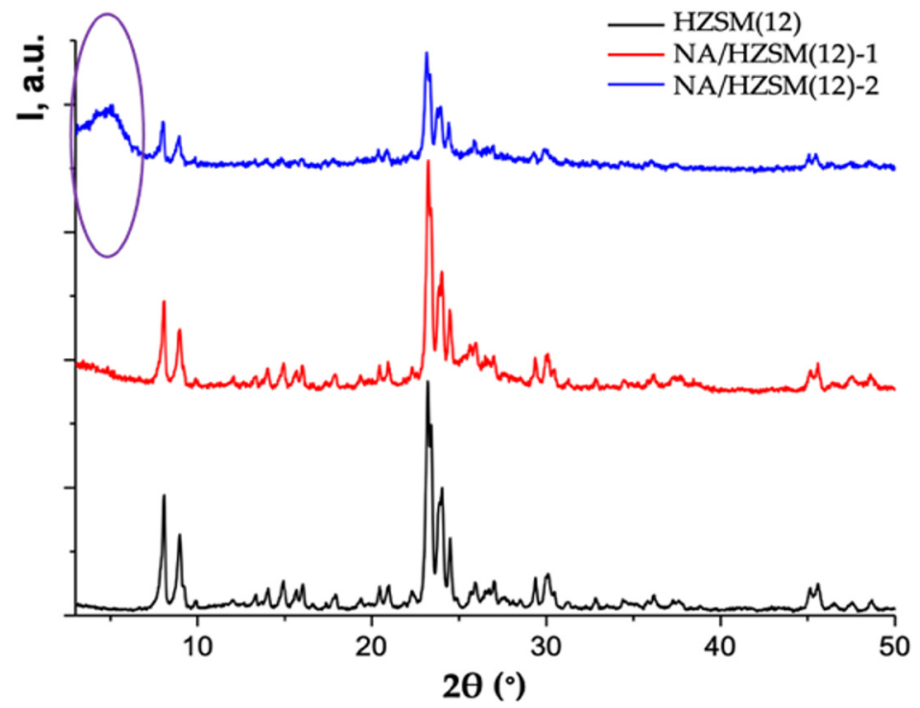

(a)

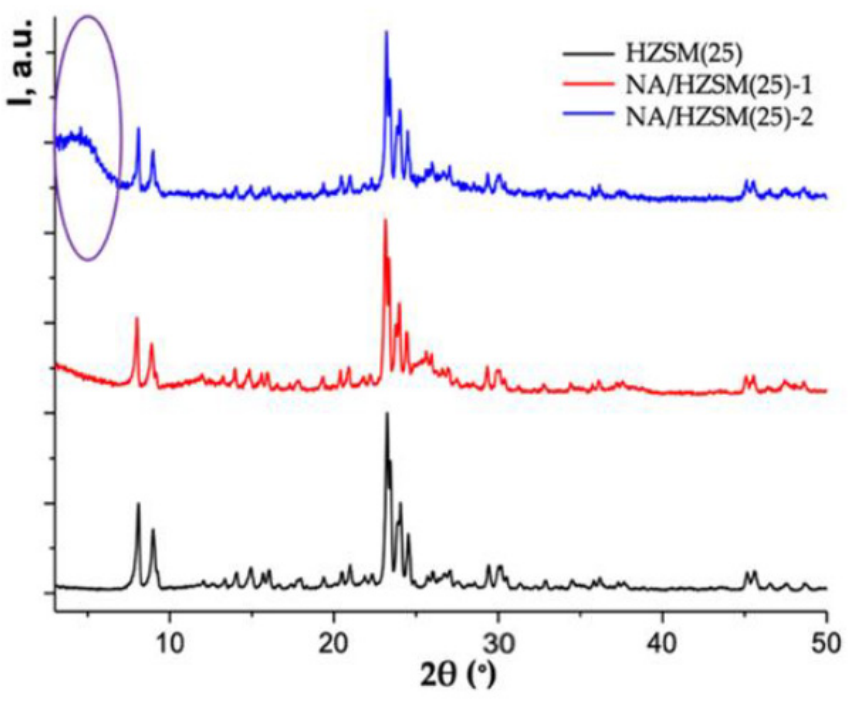

(b)

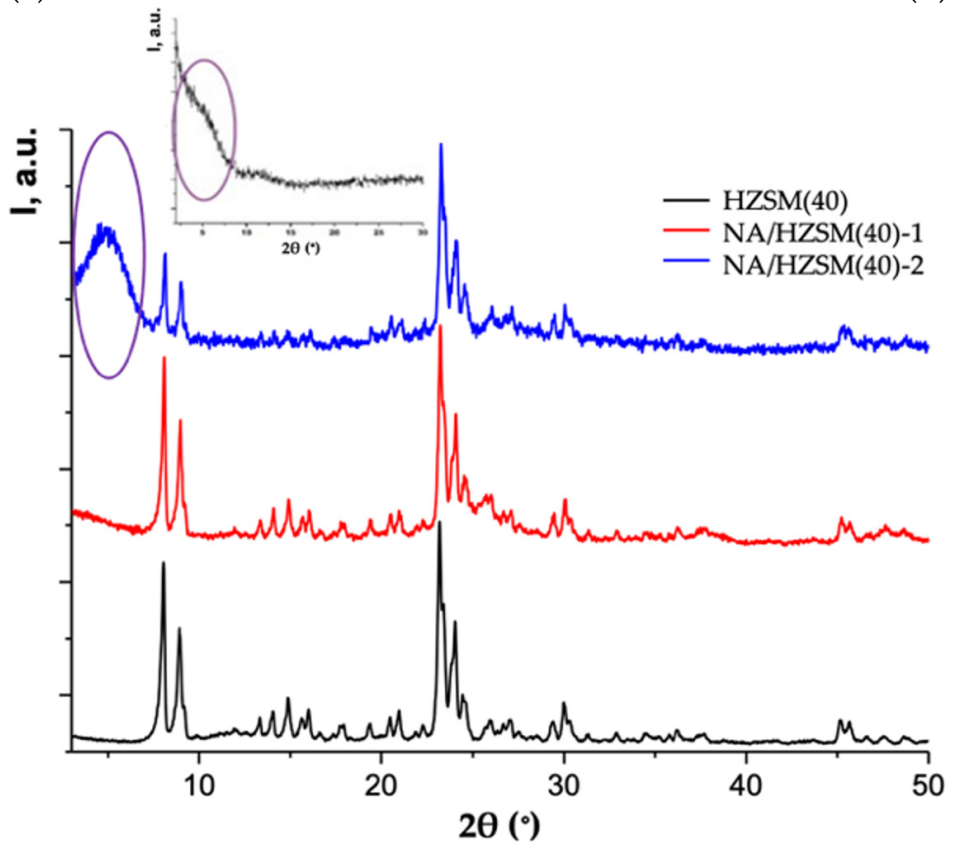

(c)

Figure 5. X-ray patterns of HZSM and NA/HZSM-1, 2 with Si / Al = 12 (a), 25 (b), 40 (c). Inset in (c) —X-ray pattern of dried and powdered titanium tetrabutoxide $\mathrm{Ti}\left(\mathrm{C}_{4} \mathrm{H}_{9} \mathrm{O}\right)_{4}(\lambda-1.54051 \AA$ ) (adapted from [16]).

In NA/HZSM samples with $\mathrm{Si} / \mathrm{Al}=12,40,300$, in addition to the main zeolite phase, diffuse peaks from nanosized anatase are present (mostly in NA/HZSM with Si $/ \mathrm{Al}=12$ ) (Figure S1a-c, black arrow), which was taken into account in the full-profile method.

The increase in water content in the framework cavities of HZSM and NA/HZSM is in direct ratio to the increase in $\mathrm{Si} / \mathrm{Al}$ and the volume of their unit cells (XRPD) (Figure S1d).

The unit cell volumes of HZSM(40) and corresponding composite NA/HZSM(40) are the same. For NA/HZSM(12) the unit cell volume is slightly less, and for NA/HZSM(300)more compared to zeolites $\operatorname{HZSM}(12)$ and $\operatorname{HZSM}(300)$, respectively (Table 3). These data indicate the absence of $\mathrm{Ti}^{4+}$ ions $\left(r_{\mathrm{Ti}}{ }^{\mathrm{IV}}=0.42 \AA\right)$ incorporation into the framework of $\mathrm{NA} / \mathrm{HZSM}(12)$ and NA/HZSM(40) structures. In addition, the structural movement of $\mathrm{Al}^{3+}$ from the inner framework $\left(\mathrm{H}^{1+}{ }_{\mathrm{x}}\right)\left[\mathrm{Al}^{3+}{ }_{\mathrm{x}} \mathrm{Si}^{4+}{ }_{12-\mathrm{x}} \mathrm{O}_{24}\right] \times w \mathrm{H}_{2} \mathrm{O}$ to the outer one $\left(\mathrm{Al}^{3+}{ }_{\mathrm{y}}\left[\mathrm{Al}^{3+}{ }_{\mathrm{x}-\mathrm{y}} \mathrm{Si}^{4+}{ }_{12-\mathrm{x}-\mathrm{y}} \mathrm{O}_{24}\right] \times w \mathrm{H}_{2} \mathrm{O}\right)$ is excluded, as the nanocomposites dealumination occurs at a temperature range of 873-1073 K [130]. 
The compositions of NA/HZSM(25)-1 and NA/HZSM(25)-2 also differ with the presence of amorphous formations in NA/HZSM(25)-2: a small-angle diffuse peak at $2 \theta \sim 5^{\circ}$ in the XRPD patterns of NA/HZSM-2 (marked with an oval) which is absent in NA/HZSM-1 (Figure 5).

It is the metastable polymeric titanium-containing phase that is responsible for this peak. Titanyl ions are known to form hydroxo complexes in aqueous solution [131], in which titanium atoms are linked through ol bridges, which can transform into oxo bonds during the thermal hydrolysis. This hydrolysis product nearly corresponds to $\mathrm{TiO}(\mathrm{OH})_{2}$ in gross composition, and is called metatitanic acid $\mathrm{H}_{2} \mathrm{TiO}_{3}$. It is one of the possible acids of the total composition $\mathrm{H}_{2} \mathrm{Ti}_{\mathrm{x}} \mathrm{O}_{2 x+1}$, formed from the initial precursor $\mathrm{Ti}\left(\mathrm{C}_{4} \mathrm{H}_{9} \mathrm{O}\right)_{4}$ (a diffuse peak at $2 \theta^{\circ} \sim 5^{\circ}$ in the inset to Figure $5 \mathrm{c}$ ). In the polyion of this acid (acids), some of the basic groups can be replaced by different structural groups, including $\mathrm{OH}^{-}$groups, water $\left(\mathrm{H}_{2} \mathrm{Ti}_{\mathrm{x}} \mathrm{O}_{2 \mathrm{x}+1} \times n \mathrm{H}_{2} \mathrm{O}\left(\mathrm{Ti}_{\mathrm{x}} \mathrm{O}_{2 \mathrm{x}-1}(\mathrm{OH})_{2} \times n \mathrm{H}_{2} \mathrm{O}\right.\right.$ [132]), organic anion, with the formation of a polymerization product in the form of chains of different dimensions.

FTIR spectroscopy is one of the most available and informative methods, except for XRPD, to characterize such objects. It allows for the provision of data on the crystallinity degree, qualitative and quantitative phase composition, on individual bonds between atoms, groups of atoms, the form of water and $\mathrm{OH}$ groups, and their location both in the zeolite framework and on the surface of the particles and inside the pores of different dimensions. FTIR spectra of HZSM (Figure 6a) in the absorption range up to $1300 \mathrm{~cm}^{-1}$ shows the framework structural groups vibrations, which are subdivided into vibrations of bonds between tetrahedra and within individual tetrahedra.

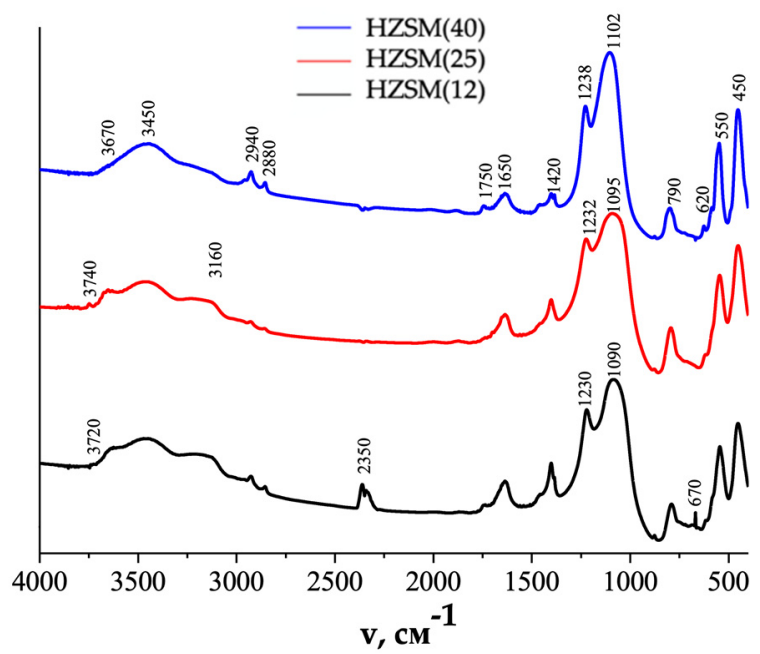

(a)

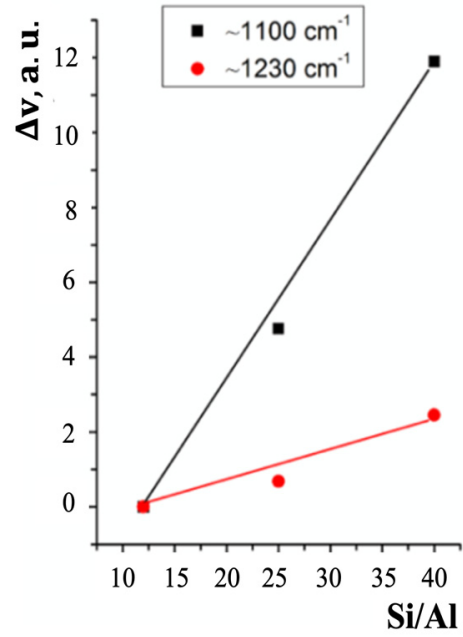

(b)

Figure 6. FTIR spectra of HZSM in coordinates Intensity (arbitrary units, a.u.)—absorption frequency $\left(\mathrm{v}, \mathrm{cm}^{-1}\right)(\mathbf{a})(\mathrm{adapted}$ from [16]); dependence of the wavelength change $(\Delta v$, a.u.) on $\operatorname{HZSM}(12,40,300)$ silicate modulus (Si/Al) value (b).

Antisymmetric stretching vibrations in the region of $1090-1238 \mathrm{~cm}^{-1}$ (Figure 6a) and deformation vibrations at $450 \mathrm{~cm}^{-1}$ (Figure $6 \mathrm{a}$ ) belong to the vibrations of $\mathrm{O}-\mathrm{Si}(\mathrm{Al})-\mathrm{O}$ bonds inside $\mathrm{Si}(\mathrm{Al}) \mathrm{O}_{4}$ tetrahedra. Bands at 550,575 , and $620 \mathrm{~cm}^{-1}$, symmetric stretching vibration at $790 \mathrm{~cm}^{-1}$ (Figure 6a), and antisymmetric stretching vibrations in the region of 1090 $1102 \mathrm{~cm}^{-1}$ (Figure 6a) characterize the vibrations of $\mathrm{Si}(\mathrm{Al})-\mathrm{O}-\mathrm{Si}(\mathrm{Al})$ external bonds between $\mathrm{Si}(\mathrm{Al}) \mathrm{O}_{4}$ tetrahedra. The higher intensity of the bands in the ranges of $450-620 \mathrm{~cm}^{-1}$ and 1090-1102 $\mathrm{cm}^{-1}$ in HZSM(40) FTIR spectra as compared to HZSM(12) and HZSM(25) (Figure 6a) can be explained by the lower content of aluminum within the HZSM(40) framework.

The absorption bands positions in the ranges of $\sim 1080$ to $1105 \mathrm{~cm}^{-1}$ and $\sim 1220$ to $1250 \mathrm{~cm}^{-1}$ are related to the value of HZSM silicate modulus (Figure 6a): an increase in $\mathrm{Si} / \mathrm{Al}$ is accompanied by a shift of the bands to the high-frequency region $\left(\Delta \mathrm{v}, \mathrm{cm}^{-1}\right)$. The 
increase in $\mathrm{Si} / \mathrm{Al}$ is in direct ratio to the increase in $\Delta \mathrm{v}, \mathrm{cm}^{-1}$ volume (Figure 6b), which makes it possible to evaluate the composition of HZSM framework (Si/Al) from FTIR spectroscopy data.

The absorption bands in the regions of $\sim 1650 \mathrm{~cm}^{-1}$ and $\sim 3450 \mathrm{~cm}^{-1}$ (Figure 6a) belong to the bending vibrations of water molecules and $\mathrm{OH}$-groups, respectively [133-135]. The band $\sim 3160 \mathrm{~cm}^{-1}$ (Figure 6a) is responsible for the stretching vibrations of $\mathrm{OH}$-groups of "zeolite water" (water molecule size is $0.28 \mathrm{~nm}$ ) in the framework voids (void sizes are from 0.53 to $0.59 \mathrm{~nm}$ ) linked by hydrogen bonds [133]. With an increase in $\mathrm{Si} / \mathrm{Al}$ in the row $\operatorname{HZSM}(12)>\operatorname{HZSM}(25)>\operatorname{HZSM}(40)$, the intensity of the bands $\sim 1600$ to $1650 \mathrm{~cm}^{-1}$ and $\sim 3100$ to $3360 \mathrm{~cm}^{-1}$ decreases (Figure 6a), i.e., the water content on the particle surface and in the zeolite framework voids decreases, respectively. With a decrease in the intensity of the $\sim 3450 \mathrm{~cm}^{-1}$ band in the row $\operatorname{HZSM}(40)>\operatorname{HZSM}(25)>\operatorname{HZSM}(12)$ (Figure 6a), the content of $\mathrm{OH}$ groups decreases.

The bands at $\sim 1750 \mathrm{~cm}^{-1}$ and $\sim 2880$ to $2940 \mathrm{~cm}^{-1}$ with low intensities (Figure 6a) correspond, respectively, to vibrations of $\mathrm{C}=\mathrm{O}$ groups and templates cations $\left(\mathrm{C}_{8} \mathrm{H}_{20}\right)^{1+}$, $\left(\mathrm{C}_{4} \mathrm{H}_{9}\right)^{1+}$ and, probably, $\left(\mathrm{C}_{3} \mathrm{H}_{7}\right)^{1+}$ in $\operatorname{HZSM}(40), \operatorname{HZSM}(25)$, and $\operatorname{HZSM}(12)$ frameworks voids with the maximum content for $\operatorname{HZSM}(40)$. This is due to the larger specific surface area of HZSM(40) (Table S3) and the maximum number of $\mathrm{C}-\mathrm{H}\left(\mathrm{CH}_{3}, \mathrm{CH}_{2}, \mathrm{CH}\right)$ bonds in the $\left(\mathrm{C}_{8} \mathrm{H}_{20}\right)^{1+}$ cation.

Judging by the intensity and appearance, the band at $\sim 2350 \mathrm{~cm}^{-1}$ (Figure $6 \mathrm{a}$ ) in the $\operatorname{HZSM}(40)$ spectrum is caused by adsorbed $\mathrm{CO}_{2}$ molecules (molecule size is $0.33 \mathrm{~nm}$ ) in the pores with the largest sizes in $\operatorname{HZSM}(40)$ (Table S3). A different form and intensity of the band at $\sim 2350 \mathrm{~cm}^{-1}$ in HZSM(12) spectrum (Figure 6a) is responsible for N-H group stretching vibrations, which forms a strong bond with water oxygen $\left(-\mathrm{N}-\mathrm{H}^{+} \ldots \mathrm{O}\right)$. This band is possible to be caused by the template cation $\left[\left(\mathrm{C}_{3} \mathrm{H}_{7}\right)_{4} \mathrm{~N}\right](\mathrm{OH})$ in the commercial sample HZSM(12) framework voids, the background of which is unknown (Section S1). The same reason is for the appearance of the band at $\sim 670 \mathrm{~cm}^{-1}$, which is present in the spectrum of only this sample (Figure 6a) and is responsible for $\mathrm{C}-\mathrm{H}$ bond deformation vibrations.

Analysis of the stretching vibrations intensity in the regions of $\sim 3650$ to $3680 \mathrm{~cm}^{-1}$ and $\sim 3720$ to $3740 \mathrm{~cm}^{-1}$ allows us to judge Brønsted acid sites (Figure 6a) [16]. The content of bridging hydroxyls $\mathrm{Si}^{4+}-\mathrm{OH}-\mathrm{Al}^{3+}\left(\sim 3650\right.$ to $3680 \mathrm{~cm}^{-1}$ [133]) in HZSM structure large cavities as well as weak terminal silanol groups Si-OH $\left(\sim 3720 \mathrm{~cm}^{-1}\right.$ and $\sim 3740 \mathrm{~cm}^{-1}$, respectively, in the inner framework for HZSM (12) and in the outer frame for all HZSM [136]) is greater in $\operatorname{HZSM}(25)$ than in $\operatorname{HZSM}(12)$. These groups are practically absent in $\operatorname{HZSM}(40)$, although there is a shoulder at $\sim 3670 \mathrm{~cm}^{-1}$ (Figure 6a). The high content of bridging hydroxyls in $\operatorname{HZSM}(25)$ is probably caused by the presence in it of a higher impurity $\mathrm{Fe}^{3+}$ ions content $\left(\mathrm{Si}^{4+}-\mathrm{OH}-\mathrm{Fe}^{3+}\right)$ (Table S1), which together with $\mathrm{Al}^{3+}$ ions $\left(\mathrm{Si}^{4+}-\mathrm{OH}-\mathrm{Al}^{3+}\right)$ are responsible for the formation of $\mathrm{OH}$-groups in zeolite framework [16].

In the FTIR spectra of the NA/HZSM-1 (Figure 7a) and NA/HZSM-2 (Figure 7b) nanocomposites, the bands responsible for Ti-O-Ti and Ti-O natural fundamental vibrations of NA $\left(\sim 400\right.$ to $\left.700 \mathrm{~cm}^{-1}\right)$, as well as for the bending $\left(\sim 3420 \mathrm{~cm}^{-1}\right)$ and stretching $\left(\sim 3200 \mathrm{~cm}^{-1}\right)$ vibrations of the Ti-OH groups [16,137], are superimposed on the corresponding bands of the initial zeolites (Figure 6), which can be judged by the appearance of additional shoulders in the range of $400-550 \mathrm{~cm}^{-1}$ vibrations, most noticeable in the NA/HZSM-2 spectra (Figure 7b). 


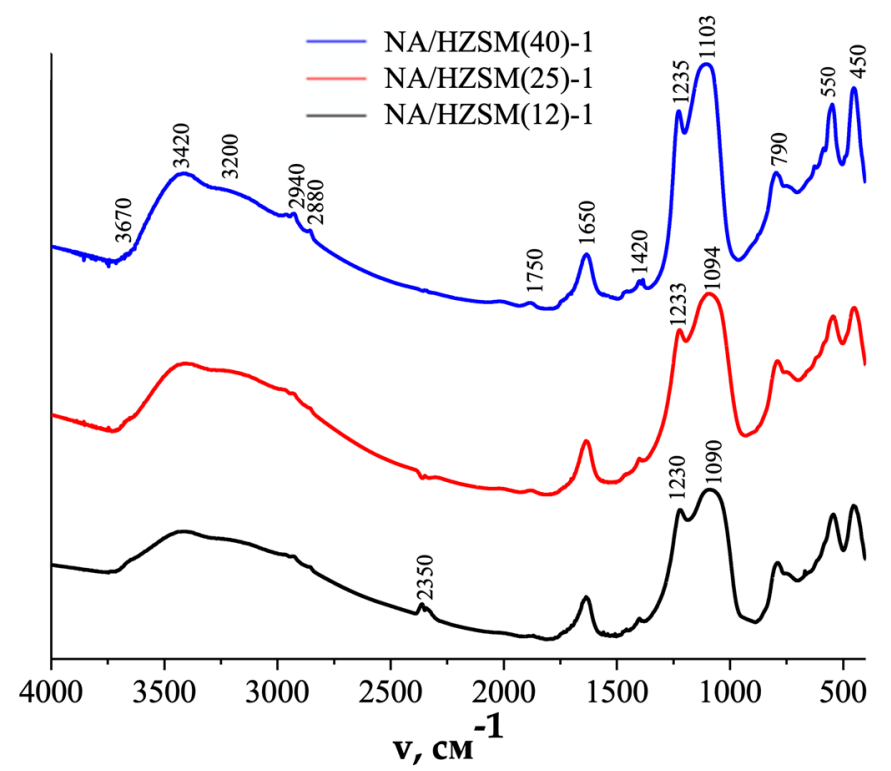

(a)

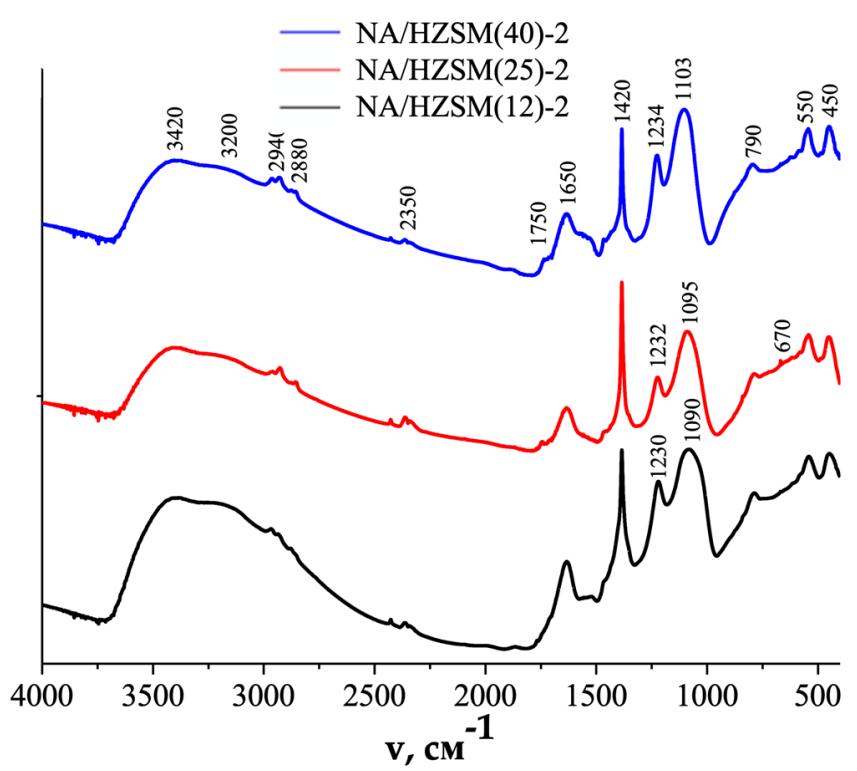

(b)

Figure 7. FTIR spectra of NA/HZSM-1 (a) and NA/HZSM-2 (b) in coordinates Intensity (arbitrary units, a.u.)—absorption frequency $\left(\mathrm{v}, \mathrm{cm}^{-1}\right)$ (adapted from [16]).

At that, the nanocomposites exhibit a decrease in the content of Brønsted acid sites in NA/HZSM-1 (marked with an oval in Figure 7a) compared to the initial zeolites (Figure 6a) and almost their absence in NA/HZSM-2 (marked with an oval in Figure $7 \mathrm{~b}$ ). An increase in the content of water $\left(\sim 1650 \mathrm{~cm}^{-1}\right)$ and $\mathrm{OH}$ groups $\left(\sim 3420 \mathrm{~cm}^{-1}\right)$, but a decrease in the content of "zeolite water" with $\mathrm{OH}$-groups in the framework voids linked by hydrogen bonds $\left(\sim 3200 \mathrm{~cm}^{-1}\right)$ were also found in nanocomposites (Figure 7$)$ as compared to the initial HZSM (Figure 6a).

Differential scanning calorimetry (DSC) results (Table 4, Figure S2) confirm the FTIR spectroscopy data on the decrease in physically adsorbed water together with $\mathrm{OH}$ groups on HZSM zeolite particles surface and in the framework voids with an increase in $\mathrm{Si} / \mathrm{Al}$, which does not contradict the XRPD results (Figure S1d). 
Table 4. Correspondence of peaks (T, K) in HZSM and NA/HZSM-1,2 DSC thermograms to possible thermal processes.

\begin{tabular}{|c|c|c|c|c|c|c|c|c|c|c|}
\hline & HZSM(12) & $\begin{array}{l}\text { NA/HZSM } \\
\text { (12)-1 }\end{array}$ & $\begin{array}{l}\text { NA/HZSM } \\
\text { (12)-2 }\end{array}$ & $\operatorname{HZSM}(25)$ & $\begin{array}{l}\text { NA/HZSM } \\
\quad(25)-1\end{array}$ & $\begin{array}{l}\text { NA/HZSM } \\
\quad(25)-2\end{array}$ & HZSM(40) & $\begin{array}{l}\text { NA/HZSM } \\
\quad(40)-1\end{array}$ & $\begin{array}{l}\text { NA/HZSM } \\
\quad(40)-2\end{array}$ & Thermal Process \\
\hline $\mathrm{T}, \mathrm{K}$ & 346.9 & & & 331 & & & 339.5 & & & \multirow{2}{*}{$\begin{array}{l}\text { Removal of physically adsorbed different } \\
\text { water }[16,138]\end{array}$} \\
\hline$H, \mathrm{~J} / \mathrm{g}$ & -170.8 & & & -134.6 & & & -37.07 & & & \\
\hline $\mathrm{T}, \mathrm{K}$ & & 384 & 364 & & 368.6 & 361.2 & & 360.9 & 342.4 & \multirow{2}{*}{$\begin{array}{l}\text { Removal of physically adsorbed different } \\
\text { water of the nanocomposites [16] }\end{array}$} \\
\hline$H, \mathrm{~J} / \mathrm{g}$ & & -190.1 & -140.2 & & -191.6 & -199.7 & & -147.1 & -153.9 & \\
\hline $\mathrm{T}, \mathrm{K}$ & 454.2 & & & 436.6 & & & 429.3 & & & \multirow{2}{*}{$\begin{array}{l}\text { Removal of OH groups from the surface of } \\
\text { the zeolite }[16,138]\end{array}$} \\
\hline$H, \mathrm{~J} / \mathrm{g}$ & -60.4 & & & -49.06 & & & -18.3 & & & \\
\hline $\mathrm{T}, \mathrm{K}$ & & 450,7 & 420.7 & & 455.7 & 412.7 & & 490.7 & 434.6 & \multirow{2}{*}{$\begin{array}{l}\text { Removal of OH groups from the surface of } \\
\text { the nanocomposites [16] }\end{array}$} \\
\hline$H, \mathrm{~J} / \mathrm{g}$ & & -31.3 & -32.4 & & -30.1 & -47.4 & & -49.9 & -60.2 & \\
\hline $\mathrm{T}, \mathrm{K}$ & - & - & 467.3 & - & - & 441 & - & - & - & \multirow{4}{*}{$\begin{array}{l}\text { Pyrolysis n-butoxide }[139,140] \\
(1) \mathrm{TiO}(\mathrm{OBu})_{4} \rightarrow \mathrm{TiO}(\mathrm{OBu})_{2}+\mathrm{Bu}_{2} \mathrm{O} \\
(2) \mathrm{TiO}(\mathrm{OBu})_{2} \rightarrow \mathrm{TiO}_{2}+\mathrm{Bu}_{2} \mathrm{O} \\
\mathrm{Bu}_{2} \mathrm{O} \text {-dibutyl ether }\end{array}$} \\
\hline$H, \mathrm{~J} / \mathrm{g}$ & & & 302.6 & & & 217.8 & & & & \\
\hline $\mathrm{T}, \mathrm{K}$ & - & - & 512 & - & - & 526.9 & - & - & 499.9 & \\
\hline$H, \mathrm{~J} / \mathrm{g}$ & & & 26.7 & & & 34.02 & & & 103.6 & \\
\hline$H, \mathrm{~J} / \mathrm{g}$ & 18.4 & & & & & & & & & $\begin{array}{l}\text { Probably, the phase transition of MOR } \\
\text { impurity phase in HZSM-5 [16] }\end{array}$ \\
\hline $\mathrm{T}, \mathrm{K}$ & 733 & & & 694.2 & & & 699.7 & & & \multirow{2}{*}{$\begin{array}{l}\text { Removal of "zeolite water" with OH-groups } \\
\text { from zeolite framework voids }[16,141]\end{array}$} \\
\hline$H, \mathrm{~J} / \mathrm{g}$ & -102.7 & & & -64.77 & & & -14.58 & & & \\
\hline $\mathrm{T}, \mathrm{K}$ & & 680.6 & 663.2 & & 685.4 & 662.7 & & 692 & 689.6 & $\begin{array}{l}\text { Removal of "zeolite water" with OH-groups } \\
\text { from nanocomposite framework voids [16] }\end{array}$ \\
\hline
\end{tabular}


The increase in HZSM and NA/HZSM unit cell volumes is in direct ratio to the water content in the framework cavities according to DSC data (Table 4). The distinctions in the results of examining samples with different methods (XRPD and DSC) are caused by both the physical basis of the method and the dynamics of water removal (DSC).

NA addition to the system with zeolites in the synthesis of NA/HZSM-1 and NA/ HZSM-2 nanocomposites leads to an increase in the removal temperature of adsorbed water together with $\mathrm{OH}$ groups from the particle surface (mostly for NA/HZSM-1; the total content of $\mathrm{OH}$ groups is higher in $\mathrm{NA} / \mathrm{HZSM}(25)-1,2)$. At that, the desorption temperature decreases in the row NA/HZSM(12) > NA/HZSM(25) > NA/HZSM(40) (Table 4), regardless of the method of nanocomposites obtaining. It may indicate a decrease in the binding strength of active groups on NA nanoparticles surface with water molecules and $\mathrm{OH}$ groups on the zeolites surface in this series.

With an increase in the temperature, water with $\mathrm{OH}$ groups begins to remove from the near-surface layers of zeolite particles and NA nanoparticles of NA/HZSM-1, 2 composites (a higher total content for NA/HZSM(40)-1, 2, Table 4) with a decrease in the row NA/HZSM(40) > NA/HZSM(25) > NA/HZSM(12) (Table 4).

As for zeolite water (in the framework voids), the temperature of its removal from nanocomposites is lower compared to zeolites (Table 4), and the content is lower in NA/HZSM(12,25)-1, 2 and NA/HZSM(40)-2 and significantly higher in NA/HZSM(40)-1 compared to corresponding zeolites (Table 4).

HZSM zeolites differ from each other in their surface composition, which does not correlate with the bulk one, namely, with the silicate modulus: according to X-ray Photoelectron Spectroscopy (XPS), the content of Al and Si atoms decreases, respectively, in the rows $\operatorname{HZSM}(12)>\operatorname{HZSM}(40)>\operatorname{HZSM}(25)$ and $\operatorname{HZSM}(25)>\operatorname{HZSM}(12) \approx \operatorname{HZSM}(40)$ (Table 5).

Table 5. Sample surface composition (at.\%) (XPS) (data from [16]).

\begin{tabular}{|c|c|c|c|c|c|c|c|c|c|c|c|}
\hline \multirow{2}{*}{\multicolumn{2}{|c|}{$\begin{array}{c}\text { Elemental } \\
\text { Composition, } \\
\text { at. } \%\end{array}$}} & \multirow[b]{2}{*}{$\begin{array}{c}\text { Peak } \\
\text { Positions, } \\
\text { eV }^{1}\end{array}$} & \multicolumn{9}{|c|}{ Sample } \\
\hline & & & 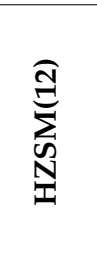 & 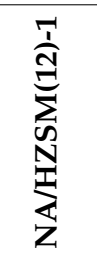 & 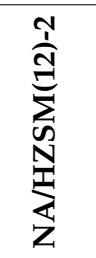 & 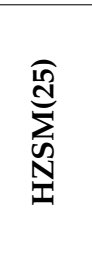 & 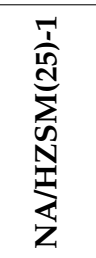 & 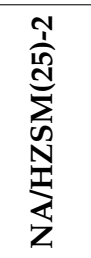 & 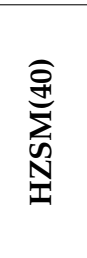 & 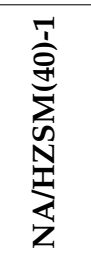 & 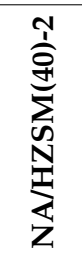 \\
\hline $\mathrm{Al} 2 \mathrm{p}$ & $\mathrm{Al}$ & $\sim 74$ to 75 & 3.27 & 2.13 & - & 2.16 & 1.54 & - & 3.08 & 1.29 & - \\
\hline Si $2 p$ & $\mathrm{Si}$ & $\sim 102$ to 103 & 30.56 & 25.17 & 6.68 & 32.08 & 23.52 & 9.62 & 30.25 & 26.46 & 7.41 \\
\hline Ti 2p & $\mathrm{Ti}^{4+}$ & $\sim 458$ to 459 & - & 5.96 & 26.17 & - & 7.31 & 25.45 & - & 4.68 & 25.32 \\
\hline \multirow{4}{*}{$\mathrm{O} 1 \mathrm{~s}$} & $\mathrm{Si}(\mathrm{Al})-\mathrm{O}$ & $\sim 532.5$ & 57.67 & 43.14 & 15.35 & 56.24 & 43.72 & 18.86 & 56.35 & 50.74 & 14.58 \\
\hline & $\mathrm{Ti}-\mathrm{O}$ & $\sim 529.8$ & - & 7.67 & 17.70 & - & 8.87 & 3.63 & - & 7.17 & 20.39 \\
\hline & $\mathrm{H}_{2} \mathrm{O}$ & $\sim 533$ to 534 & 2.01 & 5.08 & 1.20 & 1.49 & 5.96 & 8.62 & 0.67 & 2.73 & 4.58 \\
\hline & $\begin{array}{c}\mathrm{OH}- \\
\text { groups }\end{array}$ & $\sim 530$ to 531 & 6.49 & 10.84 & 32.91 & 8.02 & 9.09 & 33.82 & 9.65 & 6.93 & 27.73 \\
\hline
\end{tabular}

${ }^{1}$ Bands attribution according to [142].

Water molecules number on the zeolite particles surface decreases in the row HZSM(12) $>\operatorname{HZSM}(25)>\operatorname{HZSM}(40)$ (consistent with XRPD and DSC data; Table 4), and OH groups content decreases in the row $\operatorname{HZSM}(40)>\operatorname{HZSM}(25)>\operatorname{HZSM}(12)$ (consistent with DSC and FTIR spectroscopy data; Figure 7, Table 4).

XANES spectra at the Ti K-edge for nanocomposites are shown in Figure 8. NA/HZSM(12)-1,2 and NA/HZSM(40)-1,2 spectra coincide with each other in the absorption edge position. At the same time, NA/HZSM(25)-1,2 spectra are shifted towards higher energies, which may mean a lower formal titanium charge in NA in NA/HZSM(12)- 
1,2 and NA/HZSM(40)-1,2 as compared to NA/HZSM(25)-1,2. The XANES spectra of all samples (Figure 8a,b) contain a single pre-edge peak, which is not typical of crystalline titanium dioxide and was observed for nanosized anatase.

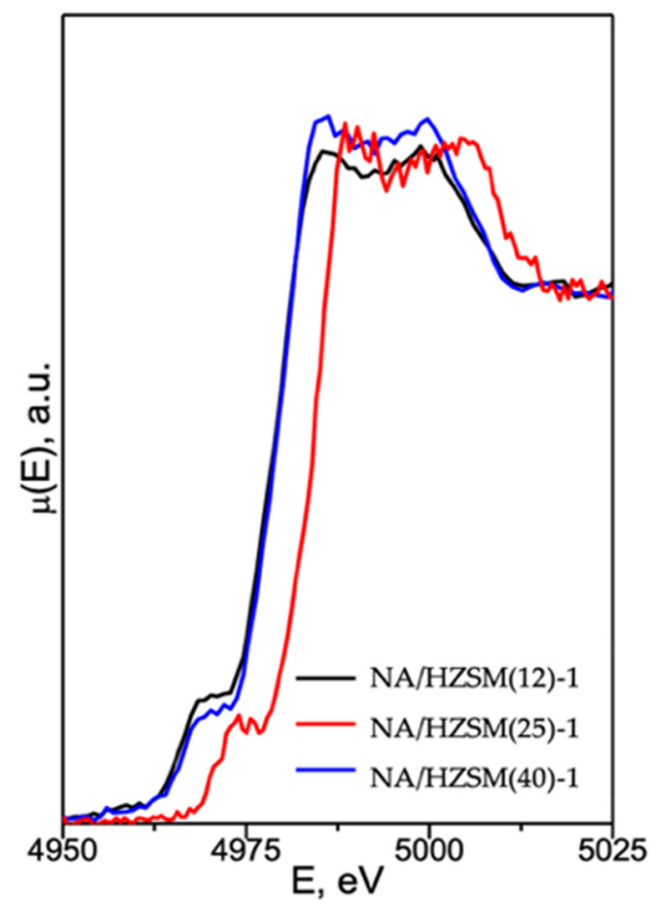

(a)

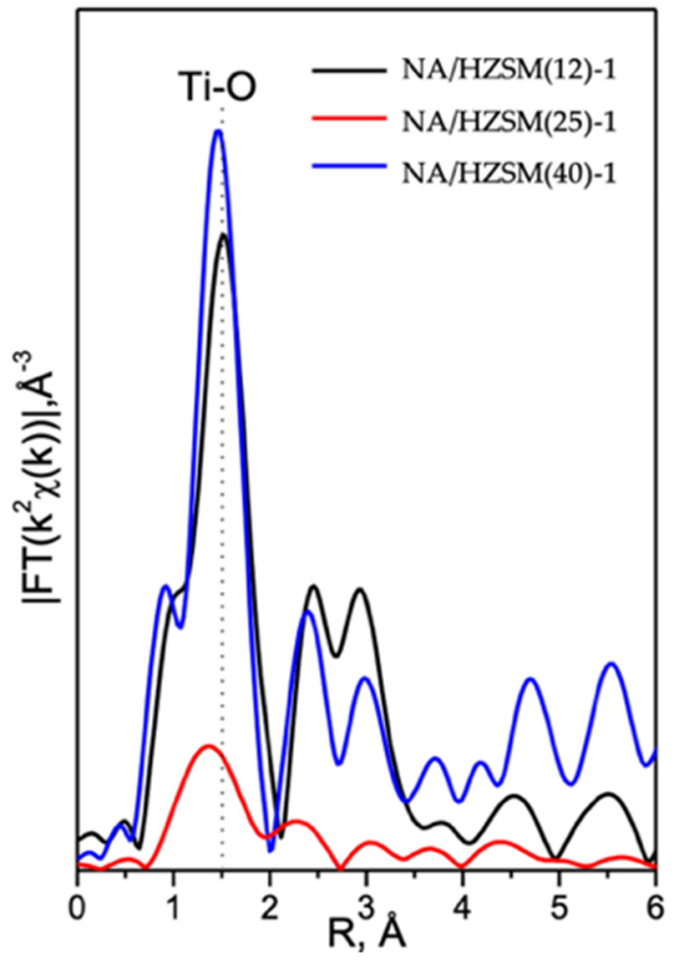

(c)

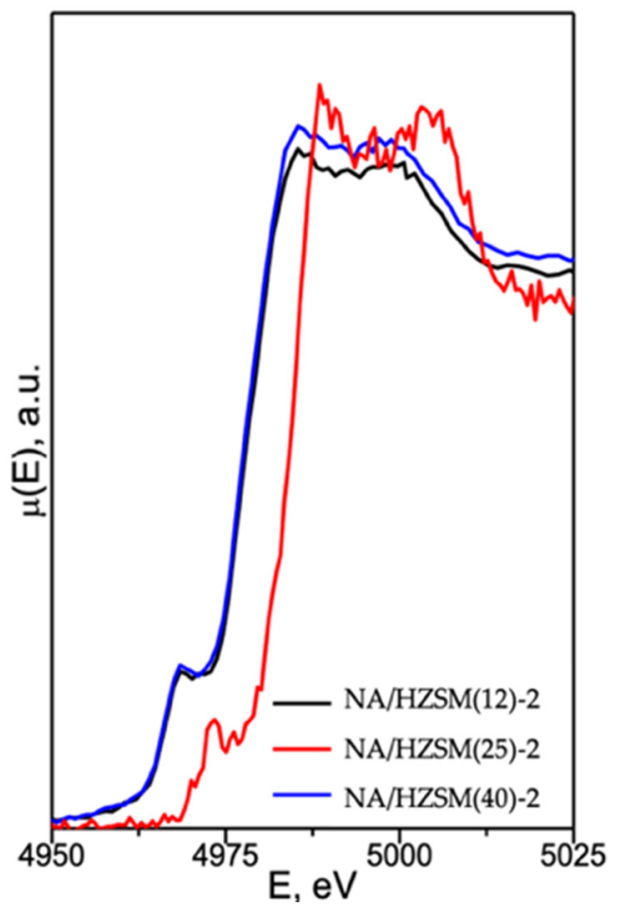

(b)

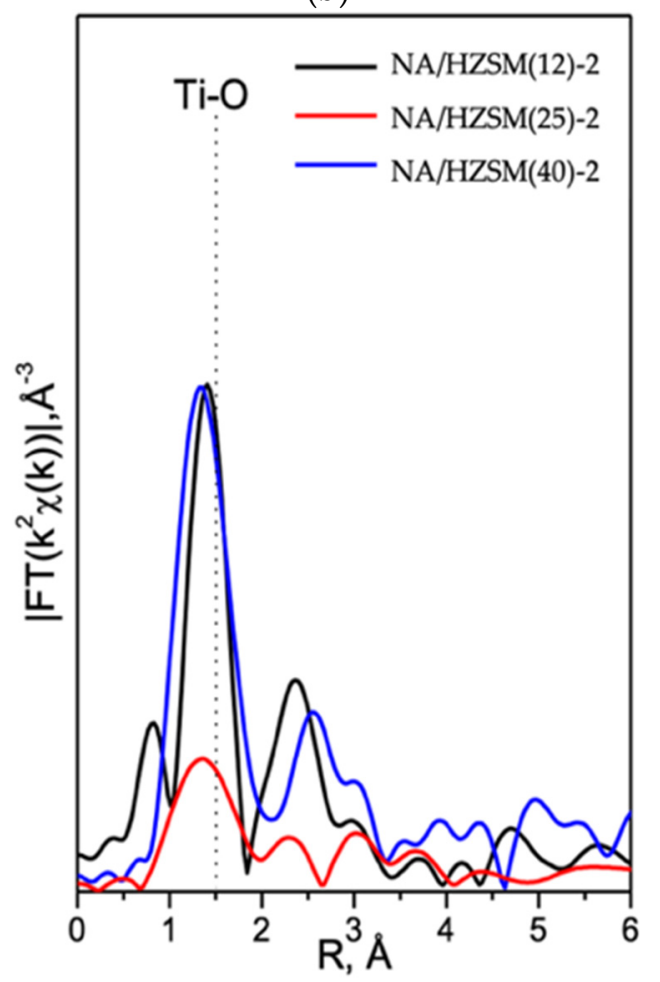

(d)

Figure 8. Ti K-edge XANES (a,b) and EXAFS (c,d) data for NA/HZSM-1, NA/HZSM-2 composites (adapted from [16]).

In the EXAFS Fourier transforms (Figure 8c,d), the most intense peak at $\mathrm{R} \sim 1.5 \AA$ corresponds to the Ti atoms oxygen environment. The results of the simplest EXAFS simulation (single Ti-O scattering path) are shown in Table 6. 
Table 6. Results of EXAFS modeling: (CN-coordination number, $\mathrm{R}_{\mathrm{Ti}-\mathrm{O}}, \AA \mathrm{A}-\mathrm{Ti}-\mathrm{O}$ interatomic distance, $\sigma^{2}-$ Debye-Waller factor, and $R_{f}$-the convergence factor). Only the first coordination sphere was modeled (distance range $\mathrm{R}=1-2 \AA$, range $\mathrm{k}=2-10 \AA^{-1}$ ) (data from [16]).

\begin{tabular}{|c|c|c|c|c|c|c|c|}
\hline & 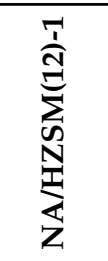 & 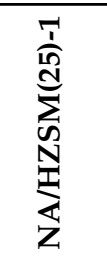 & 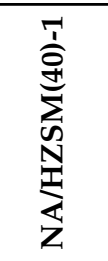 & 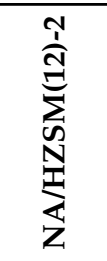 & 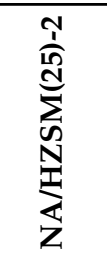 & 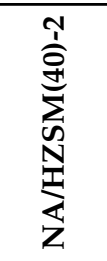 & $\overleftrightarrow{\mathrm{Z}}$ \\
\hline CN Ti & 3.4 & 3.5 & 4.1 & 2.9 & 4.6 & 2.9 & 5.8 \\
\hline $\mathbf{R}_{\text {Ti-O, }} \AA$ & 1.95 & 1.94 & 1.94 & 1.92 & 1.94 & 1.88 & 1.92 \\
\hline$\sigma^{2}, \AA^{2}$ & 0.0033 & 0.0025 & 0.0041 & 0.0051 & 0.0056 & 0.0046 & 0.0039 \\
\hline $\mathrm{R}_{\mathrm{f}}, \%$ & 3.4 & 1.9 & 1.6 & 0.8 & 4.0 & 4.7 & 1.4 \\
\hline
\end{tabular}

The oxygen peak intensity in NA/HZSM(25)-1,2 spectra is significantly lower compared to NA/HZSM(12)-1,2 and NA/HZSM(40)-1,2, but according to the simulation results, the differences in coordination numbers $(\mathrm{CN})$ are within the error. Without taking into account the determination error, $\mathrm{CN} \mathrm{Ti}=6$ in NA local structure, $\mathrm{CN} \mathrm{Ti}=4$ in NA/HZSM(40)-1, CN < 4 in NA/HZSM(12)-1 and NA/HZSM(25)-1 (Table 6). Due to the fact that the XAS method (Section S2.4) in this experiment determines the averaged coordination environment of titanium atoms by oxygen atoms, it is quite likely that the CN Ti 3 in NA/HZSM(12)-2 and NA/HZSM(40)-2 (Table 6) refers not to NA, but to titanium-containing phases, for which the diffuse reflection at at $2 \theta \sim 5^{\circ}$ (Figure 5) is responsible. $\mathrm{CN} \sim 5$ in NA/HZSM(25)-2 is most likely a superposition of the local Ti environment in NA and in titanium-containing phases. Hence, the method and conditions for nanocomposites obtaining affect the local environment of titanium atoms by oxygen atoms in titanium-containing formations, including nanosized anatase in NA/HZSM.

\subsubsection{Photocatalytic Properties of NA/HZSM}

MFI type HZSM zeolites do not exhibit photocatalytic activity (PCA), in contrast to NA/HZSM nanocomposites, whose photoactivity is caused by titanium dioxide nanoparticles with anatase structure (NA). The most famous are commercial Hombifine N (anatase), Hombikat UV100 (anatase), Degussa P25 ( 85\% anatase $+\sim 15 \%$ rutile), anatase (Sigma Aldrich, Saint Louis, Missouri, USA) with the rate constants $\left(\mathrm{k}, \mathrm{min}^{-1}\right)$ in the reaction of $\mathrm{MeO}$ model dye photodegradation (UV light, 250-400 nm, Camelion UV lamp, $26 \mathrm{~W}$; Section 3.2.3.) $\mathrm{k}=0.0123 \mathrm{~min}^{-1}, \mathrm{k}=0.0122 \mathrm{~min}^{-1}, \mathrm{k}=0.0061 \mathrm{~min}^{-1}$ and $\mathrm{k}=0.0155 \mathrm{~min}^{-1}$, respectively [143]. They demonstrate a considerable increase in its photocatalytic activity, and the doubtless advantage of nanoparticles when compared with microparticles due to the formation of very active radicals $\left({ }^{\bullet} \mathrm{OO}^{-}, \mathrm{HOOH},{ }^{\bullet} \mathrm{OH},{ }^{1} \mathrm{O}_{2}\right)$, which are called reactive oxygen species (ROS) [44,143]. The ROS formation causes a strong oxidizing ability of NA surface, which allows complete decomposition of both model and harmful organic pollutants to $\mathrm{CO}_{2}$ and $\mathrm{H}_{2} \mathrm{O}$ [144].

NA/HZSM $(12,40,300)$ nanocomposites exhibit PCA with the highest rate constants for NA/HZSM(12) (Figure 9a) under UV irradiation in photodegradation reactions of anionic dye $\mathrm{MeO}\left(\mathrm{k}_{\max }=0.01231 \mathrm{~min}^{-1}\right)$ compared to cationic $\mathrm{R} 6 \mathrm{G}\left(\mathrm{k}_{\max }=0.00321 \mathrm{~min}^{-1}\right.$, Figure 9a), but comparable to the commercial Hombifine $\mathrm{N}\left(\mathrm{k}_{\mathrm{MeO}}=0.0123 \mathrm{~min}^{-1}\right)$ and Hombikat UV100 $\left(\mathrm{k}_{\mathrm{MeO}}=0.0122 \mathrm{~min}^{-1}\right)$ [143]. 


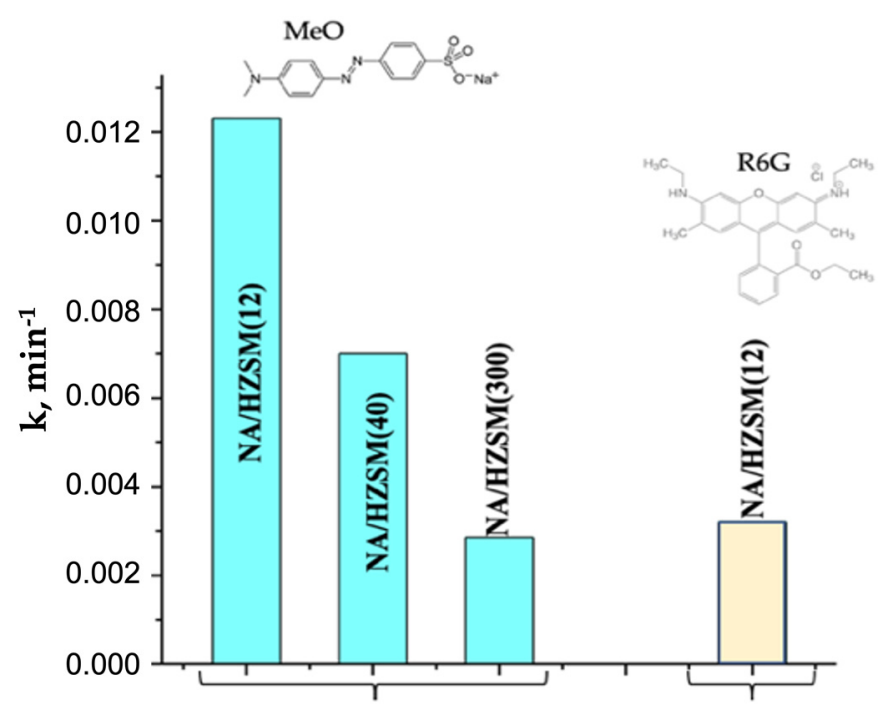

(a)

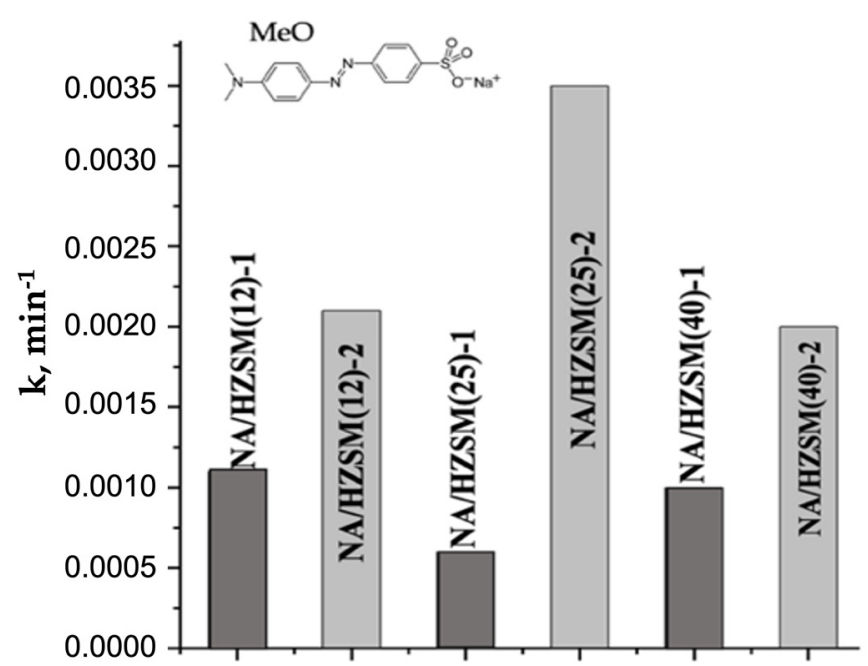

(b)

Figure 9. Photocatalytic activity of NA/HZSM obtained by Method $1 a(\mathbf{a})$ and Methods $1 b$ and 2 (b) (data from [54]).

This is explained by the fact that the anionic dye $\mathrm{MeO}$ is more likely to be adsorbed on the positively charged surface of NA nanoparticles in the composition of nanocomposites [54] than the cationic R6G. The adsorption of an organic compound on the surface of an NA-based photocatalyst is the first stage of the photocatalytic process [145], followed by the generation of charge carriers (the second stage of the photocatalytic process) under UV to form ROS. MeO dye is adsorbed on the photocatalysts surface either through the Coulomb interaction [146] (negatively charged $-\mathrm{SO}_{3}{ }^{-}$ion of the $\mathrm{MeO}$ interacts with the positively charged NA/HZSM surface) or through $\mathrm{OH}$ groups to form hydrogen bonds [147]. The nitrogen atom in the $\mathrm{MeO}$ structure $\left(\mathrm{C}_{14} \mathrm{H}_{14} \mathrm{~N}_{3} \mathrm{NaO}_{3} \mathrm{~S}\right)$ binds to $\mathrm{OH}$ groups on the surface of the nanocomposite. After charge carriers generation on the surface of NA nanoparticles under UV irradiation, ${ }^{\bullet} \mathrm{OH}$ radicals are formed in the composition of nanocomposites (reactions 5-7) [143], which oxidize MeO [148] (reaction 8):

$$
\begin{gathered}
\mathrm{TiO}_{2}+h v \rightarrow \mathrm{TiO}_{2}\left(e_{\mathrm{CB}}^{-}+h_{V B}^{+}\right), \\
\mathrm{TiO}_{2}\left(h_{V B}^{+}\right)+\mathrm{H}_{2} \mathrm{O} \rightarrow \mathrm{TiO}_{2}+\mathrm{H}^{+}+\bullet \mathrm{O}_{2}^{-}, \\
\mathrm{TiO}_{2}\left(h_{V B}^{+}\right)+\mathrm{OH}^{-} \rightarrow \mathrm{TiO}_{2}+\bullet \mathrm{OH}, \\
\bullet \mathrm{OH}+\mathrm{C}_{14} \mathrm{H}_{14} \mathrm{~N}_{3} \mathrm{NaO}_{3} \mathrm{~S} \rightarrow \text { Mineralization products }
\end{gathered}
$$

(reaction 5)

(reaction 6)

(reaction 7 )

(reaction 8 )

The highest photocatalytic activity (PCA) in the reaction of $\mathrm{MeO}$ photodegradation under UV irradiation was achieved for nanocomposite NA/HZSM(12) (Method 1a) (Figure 9) with the highest content of water molecules (more than in the initial $\operatorname{HZSM}(12))$, and hence, $\mathrm{OH}$ groups, in the structure cavities (XRPD). The PCA of NA/HZSM(12) (Figure 10, the initial sample is marked with an oval) correlates with synthesis duration (Figure 10a), NA:HZSM(12) ratio (Figure 10b) and $\mathrm{pH}$ of precursor $\left(\mathrm{TiOSO}_{4} \times \mathrm{xH}_{2} \mathrm{SO}_{4} \times \mathrm{yH}_{2} \mathrm{O}\right.$, SigmaAldrich) (Figure 10c) [54].

The only advantage of the NA/HZSM(12) nanocomposite over Hombifine $\mathrm{N}$ and Hombikat UV100 with similar rate constants is a significant decrease in the number of the active component NA in NA/HZSM(12) while maintaining the characteristics of PCA. 


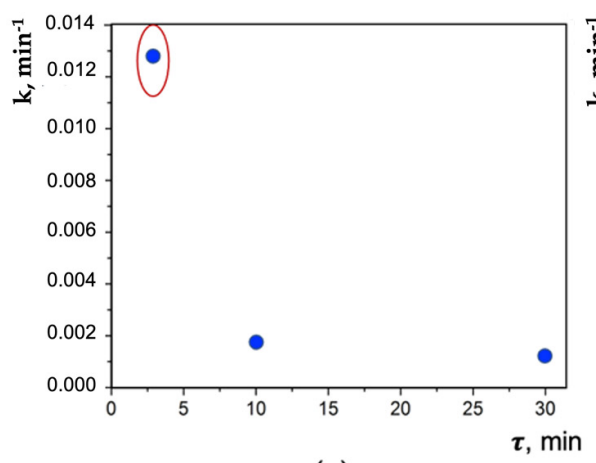

(a)

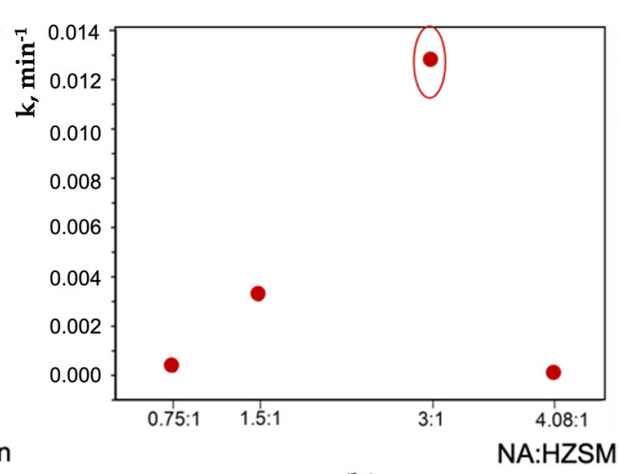

(b)

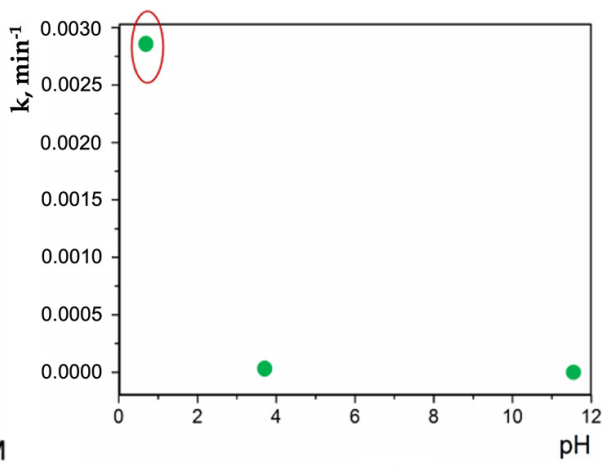

(c)

Figure 10. Relationship between the photoreaction rate constant $\left(\mathrm{k}, \mathrm{min}^{-1}\right)$ and synthesis duration $(\tau)(\mathbf{a}), \mathrm{NA}: \mathrm{HZSM}(12)$ ratio (b), $\mathrm{pH}$ of the precursor $\mathrm{TiOSO}_{4} \times \mathrm{xH}_{2} \mathrm{SO}_{4} \times \mathrm{yH}_{2} \mathrm{O}$ (c) for NA/HZSM(12) (initial NA/HZSM(12) is marked with oval) (data from [54]).

The nanocomposites fabrication by Methods $1 \mathrm{~b}$ and 2 (Section S1) leads to a decrease in PCA in $\mathrm{MeO}$ photodegradation under UV irradiation (Figure 9b) as compared to nanocomposites synthesized by Method 1a (Figure 9a). This is due, first of all, to the precursor composition and to its lesser amount in the preparation of samples by Methods $1 \mathrm{~b}$ and 2 (see Section S1), which also determines the lower content of titanium ions responsible for PCA in the systems. PCA of NA/HZSM-2 > PCA of NA/HZSM- 1 with $k_{\max }=0.0006$ $\mathrm{min}^{-1}$ for NA/HZSM(25)-2 and $\mathrm{k}_{\min }=0.0035 \mathrm{~min}^{-1}$ for NA/HZSM(25)-1. NA/HZSM-2 nanocomposites exhibiting higher PCA in $\mathrm{MeO}$ photodegradation (Figure 9b), are distinguished from NA/HZSM-1 nanocomposites by the higher content of $\mathrm{OH}$ groups and water (except for frame water) (FTIR-spectroscopy, Figure 7; DSC, Table 4) as well as $\mathrm{Ti}^{4+}$ ions on the particles surface (XPS, Table 5).

Comparison of the DSC results (Table 4) with the PCA data of NA/HZSM-2 nanocomposites (Figure $9 \mathrm{~b}$ ) reveals a $\mathrm{k}_{\max }, \mathrm{min}^{-1}$ for NA/HZSM(25)-2 with a maximum content of physically adsorbed water molecules with $\mathrm{OH}$ groups (Table 4).

According to XPS data (Table 5), the content of $\mathrm{Si}$ and $\mathrm{H}_{2} \mathrm{O}$ on the surface of zeolite particles and NA nanoparticles decreases in the same series. The content of $\mathrm{Si}, \mathrm{Si}(\mathrm{Al})$ $\mathrm{O}$ and $\mathrm{OH}$ groups is the highest in the NA/HZSM(25)-2 among other nanocomposites obtained by Method 2. For NA/HZSM(25)-2 with the largest coordination environment of titanium ions- $\mathrm{CN}$ Ti $\sim 5$ (XAS; Table 6), the highest activity in the photodegradation of $\mathrm{MeO}$ (Figure 9b) was obtained among other NA/HZSM(12, 40)-2 samples.

Thus, the PCA of nanocomposites in the NA-HZSM system depends mainly on the surface composition (i.e., correlates with the content of atoms or group of atoms) and the local structure of titanium-containing formations, giving preference to the local structure of nanosized anatase.

The photoactivity in visible light was obtained using nanocomposites based on $\operatorname{HZSM}(40)$ and $\operatorname{HZSM}(300)$ with nanosized anatase (NA) doped with transition metal ions (NA:M). NA:M/HZSM(40)-3 and NA:M/HZSM(300)-3 nanocomposites are active in the photooxidation of difenoconazole contaminants, at that, the photocatalytic activity is higher in the presence of NA:Ni/HZSM(40)-3 (Table 7) [65]. 
Table 7. Functional properties of NA:M/HZSM(40)-3 and NA:M/HZSM(300)-3 (data from [65]).

\begin{tabular}{|c|c|c|c|}
\hline \multirow{2}{*}{ Sample } & \multicolumn{3}{|c|}{ Photocatalytic Properties, Reaction Rate Constant (k, $\left.\min ^{-1}\right)$} \\
\hline & \multicolumn{2}{|l|}{ Difenoconazole } & Thiamethoxam \\
\hline NA:Ni/HZSM(40)-3 & \multicolumn{2}{|l|}{$0.0083(2)$} & $0.0007(1)$ \\
\hline$N A: A g / H Z S M(40)-3$ & \multicolumn{2}{|l|}{$0.0073(2)$} & $0.0010(1)$ \\
\hline$N A: V / H Z S M(40)-3$ & \multicolumn{2}{|l|}{$0.0069(2)$} & $0.0007(1)$ \\
\hline NA:Ni/HZSM(300)-3 & \multicolumn{2}{|l|}{$0.0077(2)$} & $0.0005(1)$ \\
\hline$N A: A g / H Z S M(300)-3$ & \multicolumn{2}{|l|}{$0.0059(2)$} & $0.0007(1)$ \\
\hline \multirow[t]{3}{*}{$N A: V / H Z S M(300)-3$} & \multicolumn{2}{|l|}{$0.0045(2)$} & $0.0004(1)$ \\
\hline & \multicolumn{3}{|c|}{ Adsorption properties (in the dark), removal degree ( $R, \%)$} \\
\hline & $\mathbf{P}(\mathbf{V})$ & $\operatorname{As}(\mathrm{V})$ & $\mathrm{Se}(\mathrm{VI})$ \\
\hline$N A: N i / H Z S M(40)-3$ & 99.35 & 99.86 & $>99.65$ \\
\hline$N A: A g / H Z S M(40)-3$ & $>99.90$ & 99.85 & $>99.65$ \\
\hline$N A: V / H Z S M(40)-3$ & $>99.90$ & 99.68 & $>99.65$ \\
\hline NA:Ni/HZSM(300)-3 & 99.64 & 99.67 & $>99.65$ \\
\hline$N A: A g / H Z S M(300)-3$ & $>99.90$ & 99.70 & $>99.65$ \\
\hline \multirow[t]{3}{*}{$N A: V / H Z S M(300)-3$} & 97.55 & 98.36 & 99.45 \\
\hline & \multicolumn{3}{|c|}{$\begin{array}{l}\text { Bactericidal properties (in the dark), diameter of inhibition growth } \\
\text { zone }(\mathrm{D}, \mathrm{mm})\end{array}$} \\
\hline & St. epidermidis & Bacillus antracoides & Es. coli \\
\hline NA:Ni/HZSM(40)-3 & 0 & 0 & 0 \\
\hline$N A: A g / H Z S M(40)-3$ & 12 & 12 & 13 \\
\hline$N A: V / H Z S M(40)-3$ & 8 & 0 & 0 \\
\hline NA:Ni/HZSM(300)-3 & 0 & 0 & 0 \\
\hline$N A: A g / H Z S M(300)-3$ & 12 & 12 & 11 \\
\hline$N A: V / H Z S M(300)-3$ & 9 & 9 & 0 \\
\hline
\end{tabular}

The presence of photocatalytic processes in the NA:M/HZSM(40)-3 systems rather than adsorption ones was shown in [65] based in the analysis of kinetic curves of the pollutants decomposition in the dark and under visible light.

Samples with NA:M/HZSM(40)-3 and NA:M/HZSM(300)-3 are almost inert in the reaction of thiamethoxam photooxidation (Table 7).

The unit cell parameters $(\mathrm{a}, \AA)$ of NA in the composition of NA:M/HZSM(40)3 nanocomposites calculated in [65] differ (smaller in NA:V/HZSM(40)-3: a $=3.784$ $\mathrm{c}=9.575 \AA$ and larger in NA:Ni/HZSM(40)-3 zeolite: $\mathrm{a}=3.822, \mathrm{c}=9.570 \AA$ ) from those of the anatase $(\mathrm{a}=3.798, \mathrm{c}=9.454 \AA)$ presented in [43]. This fact assumes that $\mathrm{Ti}^{4+}$ ions are replaced by $\mathrm{V}^{5+} / \mathrm{V}^{4+}$ and $\mathrm{Ni}^{2+}$ ions in the structure of $\mathrm{NA}\left(\mathrm{r}\left(\mathrm{Ti}^{4+}\right)=0.61 \AA, \mathrm{r}\left(\mathrm{V}^{5+}\right)=0.54 \AA\right.$ and $\mathrm{r}\left(\mathrm{V}^{4+}\right)=0.58 \AA, \mathrm{r}\left(\mathrm{Ni}^{2+}\right)=0.69 \AA, \mathrm{r}\left(\mathrm{Ni}^{3+}\right)=0.60 \AA$; ionic radii are given for the coordination number $\mathrm{CN}=6$ [95]. The absence of differences (considering a possible error of the method) between the a ( $\AA$ ) parameters of anatase and NA in the composition of NA:Ag/HZSM(40)-3 $(\mathrm{a}=3.784, \mathrm{c}=9.565 \AA)$ excludes the substitution of $\mathrm{Ti}^{4+}$ ions by $\mathrm{Ag}^{+}$ ones in the NA structure $\left(\mathrm{r}_{\left(\mathrm{Ag}^{+}\right)}\right)=1.15 \AA . \mathrm{Ag}^{+}$ions may be on the NA particles surface but not in the NA composition [65].

According to XPS data (Figure 11), among NA:M/HZSM(40)-3 samples, the smallest content of $\mathrm{OH}$ groups $(\sim 531.5 \mathrm{eV})$ (Figure 11a) was found on the surface of NA:Ag/HZSM(40)-3 zeolite particles, while $\mathrm{Ti}^{3+}$ ions content $(\sim 457 \mathrm{eV})$ was lower on the surface of NA:Ni/ $\operatorname{HZSM}(40)-3$ particles (Figure 11b). 


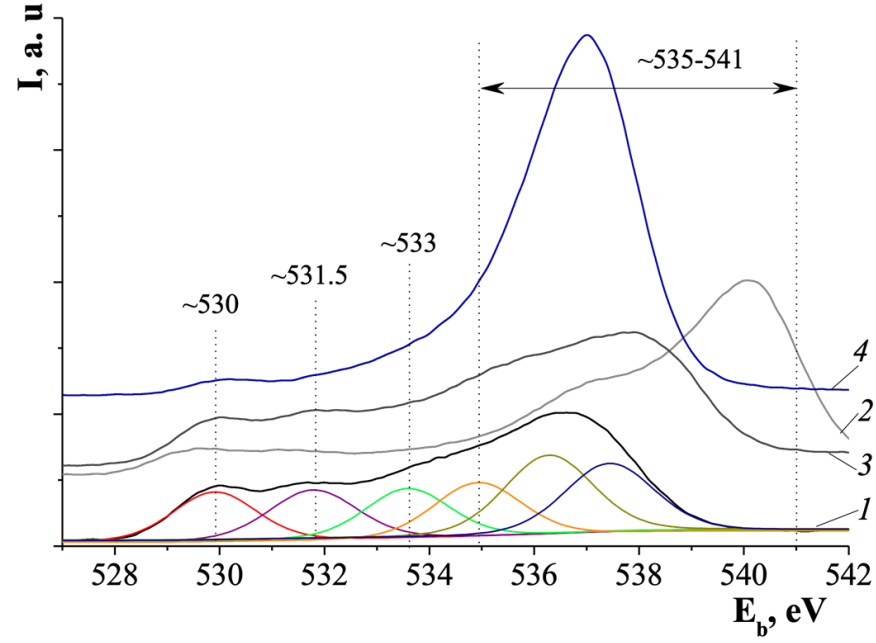

(a)

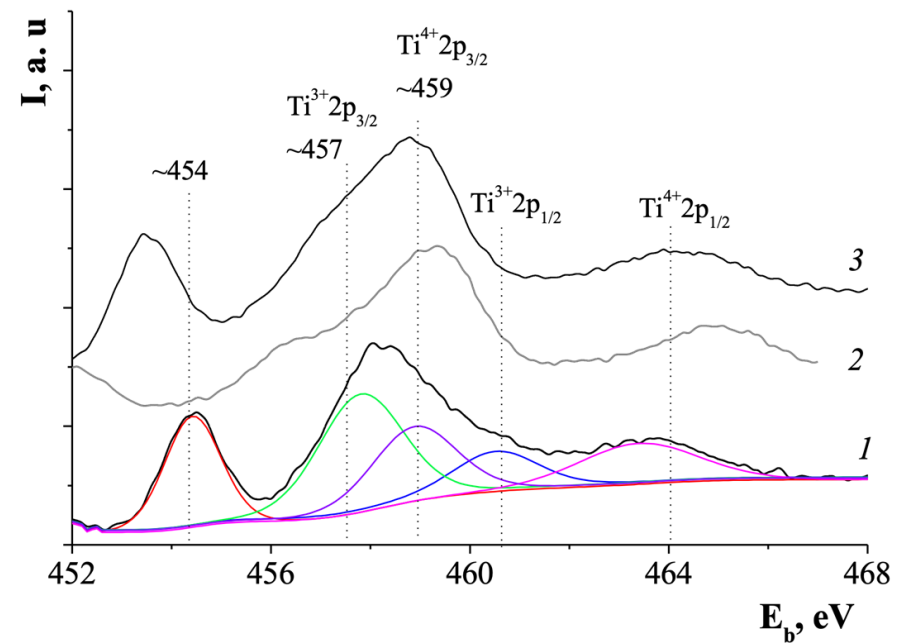

(b)

Figure 11. O2s core-level (a) and Ti2p core-level (b) X-ray photoelectron spectra of samples: NA:Ni/HZSM(40)-3 (1), NA:V/HZSM(40)-3 (2), NA:Ag/HZSM(40)-3 (3) and HZSM(40) (4) (adapted from [65]).

The analysis of NA:M/HZSM(40)-3 chemiluminescence spectra with luminol (indicator for ${ }^{\bullet} \mathrm{OH}, \bullet^{\bullet} \mathrm{O}_{2}{ }^{-}$and $\mathrm{H}_{2} \mathrm{O}_{2}[149,150]$ ) and lucigenin (indicator for ${ }^{\bullet} \mathrm{O}_{2}{ }^{-}$and $\left.\mathrm{H}_{2} \mathrm{O}_{2}[149,150]\right)$ with a comparison of the subintegral curves areas ( $\mathrm{h} v, \mathrm{eV}$ value), correlating with the number of formed ROS [65], evidences a different content of ROS on the particle surface. The content of ${ }^{\bullet} \mathrm{O}_{2}{ }^{-},{ }^{\bullet} \mathrm{OH}$ and $\mathrm{H}_{2} \mathrm{O}_{2}$ decreases in series NA:Ag/HZSM(40)-3 $>$ NA:Ni/HZSM(40)-3 > NA:V/HZSM(40)-3 [65], which does not correlate with photocatalytic activity (Table 7). It means that the photocatalytic process is multifactorial: the symbate connection of $\mathrm{k}, \mathrm{min}^{-1}$ with dopant $M$ concentration (mol\%) (more for $\mathrm{M}=\mathrm{Ni}$ ) and Ti-O was found as well as the antibatic relationship between $\mathrm{k}, \mathrm{min}^{-1}$ and $\mathrm{Ti}^{3+}$ ions content on NA:M/HZSM(40)-3 particles surface.

\subsubsection{Antimicrobial Activity in the Dark of NA/HZSM}

MFI type HZSM zeolites do not exhibit adsorption properties in contrast to NA/HZSM nanocomposites [66], whose adsorption activity is associated with anatase nanoparticles (removal degree $(R$ value, \%) of $\mathrm{P}(\mathrm{V})$ ions in the presence of NA/HZSM $(12,40,300)$ is 81-98\%) [66]. The $R$ value of $\mathrm{As}(\mathrm{V}), \mathrm{P}(\mathrm{V})$, and $\mathrm{Se}(\mathrm{VI})$ ions using NA:M/HZSM(40)-3 and NA:M/HZSM(300)-3 composites is over 99\% (Table 7) [65].

HZSM zeolites and NA/HZSM(12, 40, 300) nanocomposites do not exhibit antimicrobial properties [54] in contrast to nanocomposites NA:M/HZSM(40)-3 [65] and NA:M/ $\operatorname{HZSM}(300)-3$ (Table 7). According to [42,65], antimicrobial activity is determined both by the physicochemical parameters of the sample (bulk and surface composition, size factor, and texture parameters) and by the nature of microorganisms.

NA:Ag/HZSM(40)-3 and NA:M/HZSM(300)-3 composites demonstrate low sensitivity to Gram-positive (Staphylococcus epidermidis and Bacillus antracoides) and Gram-negative (Escherichia coli) bacteria (Table 7) that can be assumed based on the value of bacterial growth zone (diameter) inhibition [151]: up to $10 \mathrm{~mm}$-lack of sensitivity, 11-15 mm-low sensitivity, 15-25 mm-medium sensitivity, over $25 \mathrm{~mm}$ - high sensitivity to microorganisms.

NA:Ag/HZSM(40)-3 and NA:Ag/HZSM(300)-3 exhibit AMA in respect to all three microorganisms, which excludes one reason for the AMA implementation of the samples examined. AMA of nanocomposite with $\mathrm{Ag}^{+}$ions on the surface of zeolites is reasonable, i.e., silver ions have good biocidal properties. Among the numerous theories explaining the mechanisms of silver ions action (they are the ones to be on the surface of nanocomposites) on microorganisms, the most common is adsorption theory. According to it, a bacterial cell loses its viability as a result of interaction of electrostatic forces between the cell (membrane) and silver ions adsorbed on it [152]. 
Therefore, the answer to the question - what causes the bactericidal properties of the samples-should be sought, both in their physicochemical characteristics and in the nature of a specific microorganism.

\subsubsection{Catalytic Properties}

The catalytic properties of HZSM (MFI) zeolites depend on the compositions of the channels and tetrahedra in the framework and oxygen positions, the presence of $\mathrm{OH}$ groups together with oxygen atoms, surrounding $\mathrm{Si}(\mathrm{Al}))$, the matching of reactants molecules size and reaction products to the size of voids, windows, and channels. Moreover, the catalytic activity of HZSM (MFI) zeolites is determined by the crystal structure and structural characteristics $[78,153]$.

The catalytic properties of zeolites are determined with respect to the nature of acid sites (Brønsted or Lewis), their location, concentration, and strength. Two types of acid sites are known for HZSM, which determine their catalytic properties: aprotonic-Lewis sites (Figure 12a) and protonic-Brønsted sites (Figure 12b,c).<smiles>O[Al]1O[Al]2(O)O[Si](O)(O1)O2</smiles>

(a)

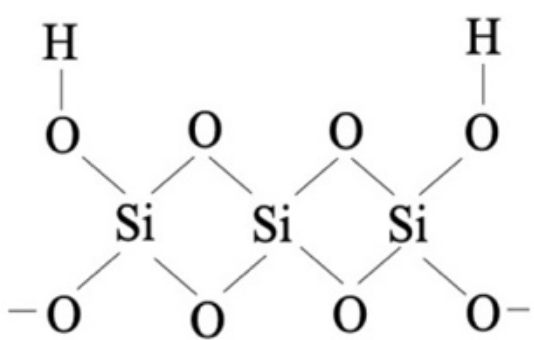

(b)

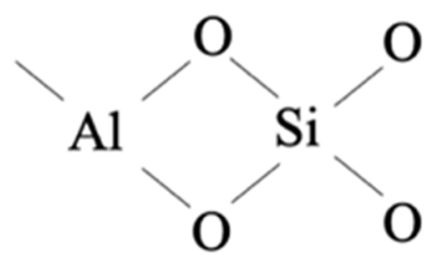

(c)

Figure 12. The structure of the bridge (a) and silanol (b) Brønsted and Lewis sites (c).

Their ratio can be changed by varying the processing modes (temperature, environmental conditions, and heating duration) of zeolites [154], as well as by modifying [155].

Catalytic systems based on HZSM zeolites with various silicate modules $(\mathrm{Si} / \mathrm{Al}=12$, $25,40)$, both initial and modified with nanosized anatase (NA/HZSM-1 and NA/HZSM-2) have been proposed for the propane and ethanol conversion.

Propane conversion $(T=473-1143 \mathrm{~K})$. There are two major mechanisms of propane $(P$, $\left.\mathrm{C}_{3} \mathrm{H}_{8}\right)$ cracking which are considered to be beneficial in terms of commercial use [16]. The first one takes place at $\mathrm{T} \geq 900$ to $\sim 1273 \mathrm{~K}$ and implies the production of propylene (PP, $\mathrm{C}_{3} \mathrm{H}_{6}$ ) by the dehydrogenation mechanism (reaction 9 ) $[16,156]$ :

$$
\mathrm{C}_{3} \mathrm{H}_{8} \rightarrow \mathrm{C}_{3} \mathrm{H}_{6}+\mathrm{H}_{2}
$$

(reaction 9$)$

The second one takes place at $\mathrm{T}>\sim 700$ to $923 \mathrm{~K}$ and leads to the formation of ethylene (ETH, $\left.\mathrm{C}_{2} \mathrm{H}_{4}\right)$ (reaction 10$)$ :

$$
\mathrm{C}_{3} \mathrm{H}_{8} \rightarrow \mathrm{C}_{4} \mathrm{H}_{4}+\mathrm{CH}_{4}
$$

(reaction 10)

Thermal cracking (reaction without a catalyst) begins after $\mathrm{T}=900 \mathrm{~K}$, while the initial HZSM zeolites and NA/HZSM-1,2 nanocomposites shift the catalytic area to lower temperatures. Using HZSM(40) allows to achieve the propane conversion value $\left(\alpha_{P}, \%\right)$ of $65 \%$ at $923 \mathrm{~K}$ (Table 8 ). In case of $\operatorname{HZSM}(12)$ and $\operatorname{HZSM}(25)$, the $\alpha_{P}$ of $30 \%$ and $48 \%$, respectively, was observed $(\mathrm{T}=923 \mathrm{~K})$ (Table 8$)$. These data are in good agreement with the values of activation energy $\left(\mathrm{E}_{\mathrm{a}}\right)$ of the propane decomposition process which decreases in the row $\operatorname{HZSM}(12)>\operatorname{HZSM}(25)>\operatorname{HZSM}(40)$ (Table 8). 
Table 8. Optimal propane cracking reaction performance $(\mathrm{T}=923 \mathrm{~K})$ (data from [16]).

\begin{tabular}{|c|c|c|c|c|c|c|c|c|c|}
\hline & 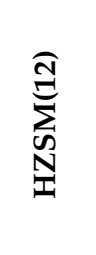 & 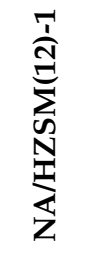 & 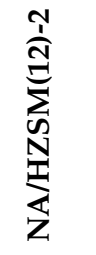 & $\underset{\substack{N\\
}}{\stackrel{1}{\mathbb{N}}}$ & 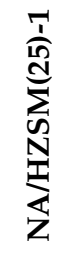 & 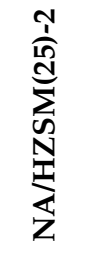 & 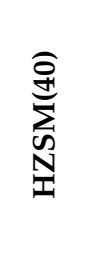 & 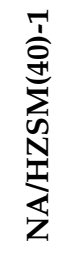 & 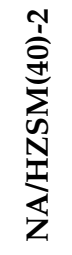 \\
\hline \multicolumn{10}{|c|}{$\alpha, \%$ (Equation (2) in Section 3.1) } \\
\hline & 30 & 29 & 47 & 48 & 49 & 66 & 65 & 65 & 78 \\
\hline \multicolumn{10}{|c|}{$\mathrm{w}, \mu \mathrm{M} /(\mathrm{gxs})$ (Equation (3) in Section 3.1) } \\
\hline $\mathrm{C}_{2} \mathrm{H}_{4}(E T H)$ & 126.9 & 139.1 & 126.9 & 150.0 & 180.0 & 165.0 & 346.2 & 440 & 540 \\
\hline $\mathrm{C}_{3} \mathrm{H}_{6}(P P)$ & 200 & 190 & 163.4 & 67.0 & 67.0 & 67.0 & 57.7 & 57.7 & 57.7 \\
\hline \multicolumn{10}{|c|}{ S,\% (Equation (4) in Section 3.1) } \\
\hline $\mathrm{C}_{2} \mathrm{H}_{4}(E T H)$ & 9 & 9 & 9 & 12 & 20 & 25 & 75 & 80 & 85 \\
\hline $\mathrm{C}_{3} \mathrm{H}_{6}(P P)$ & 82 & 75 & 70 & 9 & 9 & 9 & 6 & 9 & 12 \\
\hline \multicolumn{10}{|c|}{ TON (Equation (5) in Section 3.1.1.1) } \\
\hline & 800 & 800 & 811 & 1610 & 1621 & 1623 & 1501 & 1509 & 1511 \\
\hline \multicolumn{10}{|c|}{ Ea, kJ/mol (Equation (6) in Section 3.1.1.1) } \\
\hline & 91 & 90 & 88 & 83 & 82 & 80 & 77 & 76 & 76 \\
\hline
\end{tabular}

At $\mathrm{T}=923 \mathrm{~K}$ HZSM(40) demonstrates the maximum $E T H$ selectivity $\left(\mathrm{S}_{E T H}, \%\right)$ while $\operatorname{HZSM}(12)$ shows the maximum $P P$ selectivity $\left(\mathrm{S}_{P P}, \%\right)$ (Table 8$)$, which indicates different catalytic processes of propane cracking occurring on HZSM catalysts (Table 8):

- HZSM(12) catalyst is responsible for the formation of $P P(\operatorname{HZSM}(12)>\operatorname{HZSM}(25)$ $>\operatorname{HZSM}(40)$ ) (propane cracking reaction according to the dehydrogenation mechanism, reaction 9) [16];

- The use of HZSM(40) results in ETH formation (HZSM(40) > HZSM(25)> HZSM(12)) (destructive mechanism, reaction 10) [16].

The high ETH release yield evidences the free radical mechanism of propane cracking, close to thermal decomposition. On the other hand, the high $P P$ yield indicates a carbene catalytic cracking.

The row in which of $\mathrm{S}_{P P}, \%$ decreases and $\alpha_{P}, \%$ increases $(\mathrm{Z} 12>\mathrm{Z} 25>\mathrm{Z} 40$, Table 8) coincides with an increase in $\mathrm{Si} / \mathrm{Al}$, specific surface area and mesopores volume (Table S3), but a decrease in the content of strong acid Brønsted sites (FTIR, Figure 6), Si(Al)-O (XPS, Table 5) and strong, medium, and weak acid sites concentration (Table 9).

Alkane activation on acidic zeolites occurs either at the Brønsted acid sites or at the Lewis ones [157]. The acid site of $P$ and the carbonium ion resulting from various transformations lead to the dehydrogenation of $P$ or its cracking with the formation of $P P$ or $E T H$, respectively $[16,158]$.

The thermal dehydrogenation of propane by the reaction 9 produces $P P$ (reaction 11; $\Delta \mathrm{H}=-125.7 \mathrm{~kJ} / \mathrm{mol}$ ) with a low conversion, as compared to the destruction process by reaction 10, which proceeds with the formation of methane and ETH (reaction 12; $\Delta \mathrm{H}=-67.5 \mathrm{~kJ} / \mathrm{mol}$ ) [16]. The prevailing formation of methane during the thermal cracking of $P$ could be explained by the cleavage of the $\mathrm{C}-\mathrm{C}$ bond requires significantly less energy $(261.9 \mathrm{~kJ} / \mathrm{mol})$ than that one of the $\mathrm{C}-\mathrm{H}$ bond $(364.5 \mathrm{~kJ} / \mathrm{mol}$ for the primary carbon atom) [159].

$$
\begin{aligned}
\mathrm{C}_{3} \mathrm{H}_{8} & \leftrightarrow \mathrm{C}_{3} \mathrm{H}_{6}+\mathrm{H}_{2}, \\
\mathrm{C}_{3} \mathrm{H}_{8} & \leftrightarrow \mathrm{CH}_{4}+\mathrm{C}_{2} \mathrm{H}_{4},
\end{aligned}
$$

Modification with NA leads to an increase in $\mathrm{w}_{E T H}$ of $\operatorname{HZSM}(40)$ (Table 8). The values of $\alpha_{P}, \%$ and $\mathrm{w}_{E T H}, \mu \mathrm{M} /(\mathrm{g} \times \mathrm{s})$ decrease in the row NA/HZSM(40)-2 $>\mathrm{NA} / \mathrm{HZSM}(40)-1$ 
$>\operatorname{HZSM}(40)$ (Table 8). HZSM(12) modification with NA reduces the values of $\mathrm{S}_{P P}, \%$ and $\mathrm{w}_{P P}, \%$ in the row $\operatorname{HZSM}(12)>\mathrm{NA} / \mathrm{HZSM}(12)-1>\mathrm{NA} / \mathrm{HZSM}(12)-2$ with a slight increase in $\alpha_{P}, \%$ for NA/HZSM(12)-2 (Table 8) [16].

Table 9. Acidic properties of HZSM and NA/HZSM-2 samples (data from [16]).

\begin{tabular}{|c|c|c|c|c|c|c|c|c|c|c|}
\hline & 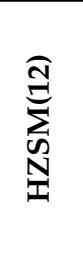 & 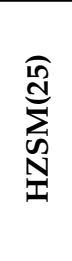 & 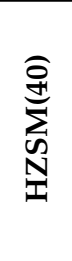 & 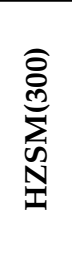 & 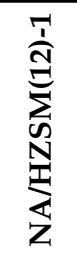 & 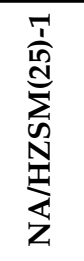 & 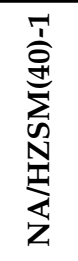 & 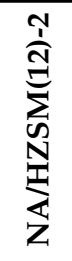 & 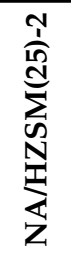 & 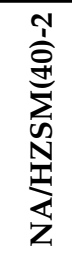 \\
\hline \multicolumn{11}{|c|}{ Low temperature peak (weak acid sites) } \\
\hline $\mathrm{T}_{\max }, \mathrm{K}$ & 479 & 462 & 486 & -1 & -1 & -1 & -1 & 447 & 470 & -2 \\
\hline $\begin{array}{c}\text { C, } \mu \mathrm{mol} / \mathrm{g} \\
(\text { Section S2.10) }\end{array}$ & 78 & 66 & 48 & -1 & -1 & -1 & -1 & 113 & 28 & -2 \\
\hline \multicolumn{11}{|c|}{ Medium temperature peak (medium acid sites) } \\
\hline $\mathbf{T}_{\max }, \mathrm{K}$ & 553 & 542 & 540 & 482 & -1 & -1 & -1 & 522 & 532 & 517 \\
\hline $\begin{array}{c}\text { C, } \mu \mathrm{mol} / \mathbf{g} \\
\text { (Section S2.10) }\end{array}$ & 421 & 343 & 116 & 75 & -1 & -1 & -1 & 332 & 176 & 36 \\
\hline \multicolumn{11}{|c|}{ High temperature peak (strong acid sites) } \\
\hline $\mathrm{T}_{\max }, \mathrm{K}$ & 783 & 768 & 760 & 635 & -1 & -1 & -1 & 733 & 761 & 615 \\
\hline $\begin{array}{c}\text { C, } \mu \mathrm{mol} / \mathbf{g} \\
\text { (Section S2.10) }\end{array}$ & 352 & 217 & 116 & 89 & -1 & -1 & -1 & 313 & 126 & 13 \\
\hline \multicolumn{11}{|c|}{$\Sigma \mathrm{C}, \mu \mathrm{mol} / \mathrm{g}$ (strong + medium acid sites) } \\
\hline & 773 & 560 & 232 & 164 & -1 & -1 & -1 & 645 & 302 & 49 \\
\hline \multicolumn{11}{|c|}{$\mathrm{N}, \mathrm{mmol} / \mathrm{g}$ (Equation (1)) } \\
\hline & 0.18 & 0.18 & 0.20 & -1 & 0.36 & 0.30 & 0.25 & 0.25 & 0.17 & 0.17 \\
\hline
\end{tabular}

${ }^{1}$ not measured; ${ }^{2}$ not found.

The value of $\alpha_{P}, \%$ is higher for NA/HZSM-2 than for NA/HZSM-1 (Table 8) which coincides with an increase in NA content in the composition of nanocomposites (NA content in the NA/HZSM-2 is higher as compared to NA/HZSM-1 according to EDX and XPS, Tables S3 and 5). The minimum concentration of acid sites and minimum CN Ti correspond to the maximum value of $\alpha_{P}, \%$ (Tables 6, 8 and 9), which indicates Lewis acid sites [16]. An increase in NA content in NA/HZSM-2 leads to an increase in $\mathrm{S}_{E T H}, \%$ (Table 8). The value of $S_{P P}, \%$ decreases for NA/HZSM(12)-1,2 (Table 8) together with a decrease in the concentration of strong acid sites in nanocomposites compared to initial $\operatorname{HZSM}(12)$ (Table 9).

$\operatorname{HZSM}(25)$ modification with NA does not change the reaction mechanism and the amount of $P P$ produced, but within the destruction reaction the equilibrium shifts towards ETH formation (Table 8) [16].

A change in the composition of the samples under the reaction conditions is a significant problem in the analysis of catalytic activity together with physicochemical characteristics, which is confirmed by the X-ray diffraction patterns of the samples before (Figure 6e) and after catalysis [16].

Analysis of NA/HZSM-1,2 diffraction patterns after propane conversion indicated an appearance of carbon-containing formations only in NA/HZSM-2 samples (diffraction peak at 20 22 ${ }^{\circ}$ ) which is consistent with their synthesis conditions (Section S1) [16].

The carbon balance was $95-100 \%$ over the entire temperature range. Propane conversion temperature increase results in water removal which contributes to $\operatorname{HZSM}(12)$ acidity 
with the maximum concentration of strong acid sites (Table 9). However, the presence of strong acid sites results in the side reaction 13 with the formation of free carbon:

$$
\mathrm{C}_{3} \mathrm{H}_{8} \rightarrow 3 \mathrm{C}+4 \mathrm{H}_{2}
$$

(reaction 13)

The coke forms on the cracking catalysts surface and remains there causing an abrupt loss of the catalyst activity (HZSM(12) has the minimum $\alpha_{p}, \%$ value among the initial zeolites, Table 8). At the same time the contribution of the destruction mechanism increases, which leads to the additional methane formation (reaction 14):

$$
\mathrm{CH}_{4} \rightarrow \mathrm{C}+2 \mathrm{H}_{2}\left(\Delta \mathrm{H}=+74.8 \mathrm{~kJ} / \mathrm{mol}^{\circ} \mathrm{C}\right)
$$

(reaction 14)

A tendency to some decrease in the carbon balance values with an increase in the temperature was observed and can be explained by an experimental error, the contribution of which is larger at small amounts of reaction products [16]. The maximum fraction of surface carbon was revealed at the maximum temperature of the propane cracking process ( $\mathrm{T} \sim 1273 \mathrm{~K}$ ). Figure 13 demonstrates the carbon accumulation on all the catalysts. A decrease in temperature by $373 \mathrm{~K}$ suppresses the process of the reaction 14 and reduces the fraction of free carbon by a factor of 10 .

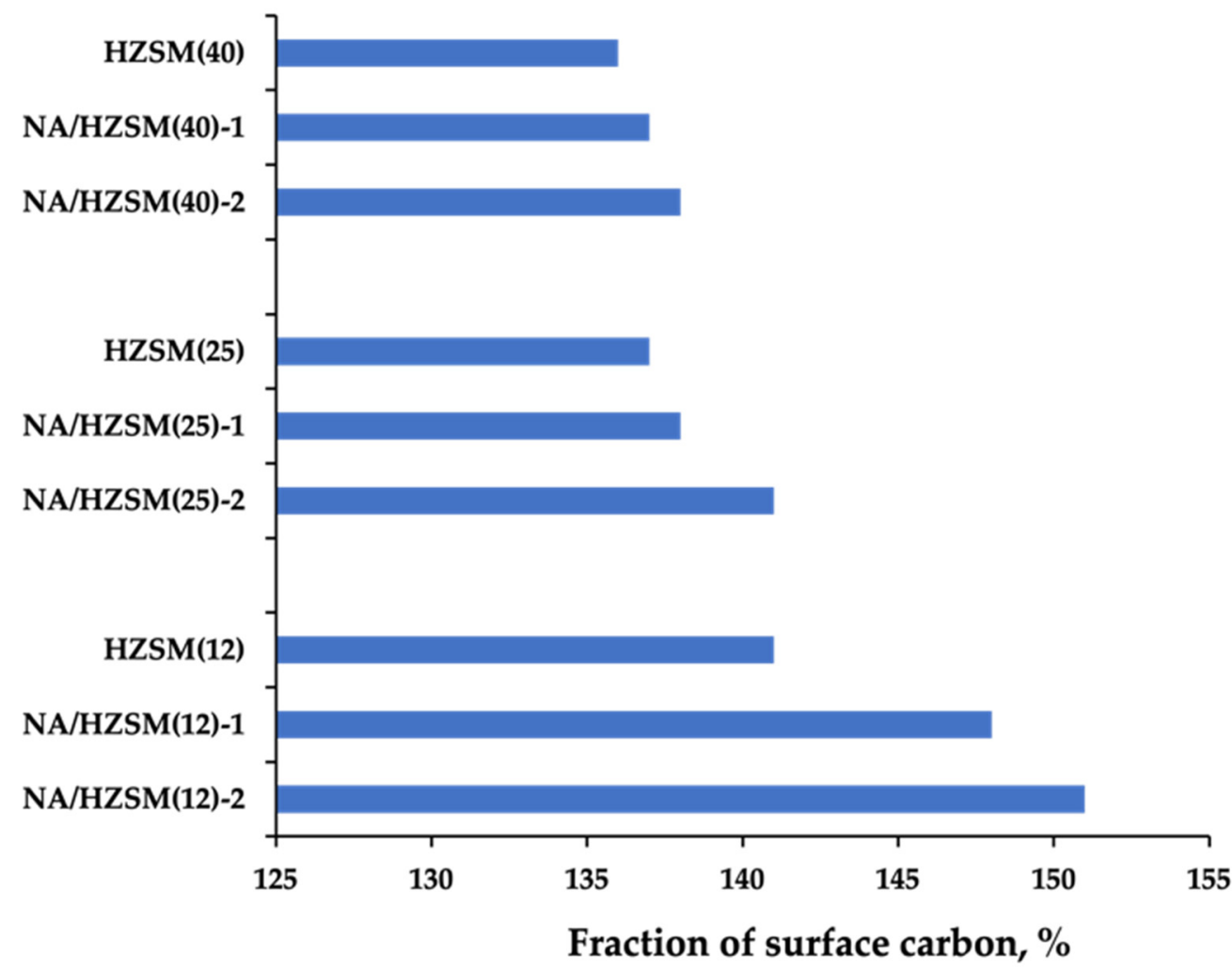

Figure 13. The amount of free carbon on the catalyst surface at $1000 \mathrm{~K}$ (data from [16]).

The highest carbon deposits formation was found in the modified samples obtained by method 2 with the carbon-containing precursor $\mathrm{Ti}\left(\mathrm{C}_{4} \mathrm{H}_{9} \mathrm{O}\right)_{4}$, which complies with the results of XRPD [16]. The data obtained on carbonization antibatically correlate with the catalytic activity: the least carbon accumulation on the catalyst surface contributes to the highest activity [16]. The catalytic systems regeneration takes place in an air stream at $\mathrm{T}=573 \mathrm{~K}$ for $10 \mathrm{~h}$. The amount of carbon remained does not exceed $10 \mathrm{wt} . \%$ and does not affect the catalytic activity of the systems studied.

The industrial processes are carried out at the $\mathrm{T} \sim 873 \mathrm{~K}$ with $P P$ selectivity on catalysts of $75-85 \%$ and propane conversion of $50-80 \%$ [160]. However, these catalytic systems are 
highly unstable to carbonization. Currently there is a trend towards industrialization of catalytic systems based on zeolites.

Ethanol conversion $(T=\sim 430-660 \mathrm{~K}$ ). Unlike propane conversion, in the conversion of ethanol $\left(E, \mathrm{C}_{2} \mathrm{H}_{5} \mathrm{OH}\right)$ on the same catalysts (HZSM, NA/HZSM-1 and NA/HZSM-2) there are no carbon-containing formations in nanocomposites after catalysis which was confirmed by the absence of the diffraction peak at $2 \theta \sim 22^{\circ}$ on NA/HZSM- 1,2 X-ray diffraction patterns after ethanol conversion [16].

The main reaction products of $E$ conversion are $E T H$ (reaction 15) and diethyl ether (DEE, $\left.\left(\mathrm{C}_{2} \mathrm{H}_{5}\right)_{2} \mathrm{O}\right)$ (reaction 16), by-product is $\mathrm{H}_{2} \mathrm{O}$.

$$
\begin{gathered}
\mathrm{C}_{2} \mathrm{H}_{5} \mathrm{OH}+\mathrm{C}_{2} \mathrm{H}_{5} \mathrm{OH} \stackrel{-\mathrm{H}_{2} \mathrm{O}}{\rightarrow}\left(\mathrm{C}_{2} \mathrm{H}_{5}\right)_{2} \mathrm{O}, \\
\mathrm{C}_{2} \mathrm{H}_{5} \mathrm{OH}^{\stackrel{\mathrm{H}_{2} \mathrm{O}}{\rightarrow}} \mathrm{C}_{2} \mathrm{H}_{4},
\end{gathered}
$$

(reaction 15)

(reaction 16)

According to [45,156], in the reaction 15 of DEE formation at $\mathrm{T} \sim 473 \mathrm{~K} E$ interacts with the proton $\left(\mathrm{H}^{+}\right)$of the Brønsted acid site, while in the reaction 16 of ETH formation at $\mathrm{T}$ $\sim 573 \mathrm{~K} \mathrm{E}$ interacts with the Lewis acid site. TPD data (Table 9) indicate that at T $\sim 73 \mathrm{~K}$ both weak and medium acid sites present in HZSM and NA/HZSM and at T $\sim 573 \mathrm{~K}$ there are only medium one.

At low temperature ( 493 to $533 \mathrm{~K})$ and conversion the reaction occurring in all cases with almost total selectivity is dehydration of $E$ to $D E E$, which means that in lowtemperature conditions the formation of $D E E$ is much faster than $E T H$ [16]. Vice versa, at higher temperature ( 513 to $633 \mathrm{~K}$ ) and conversion the reaction observed with high and almost total selectivity is the dehydration of E to ETH (Table 10).

Table 10. Selectivity of ethanol conversion to ethylene $\left(\mathrm{S}_{E T H}, \%\right)$ and diethyl ether $\left(\mathrm{S}_{D E E}, \%\right)$ for HZSM, NA/HZSM-1, and NA/HZSM-2 (data from [16]).

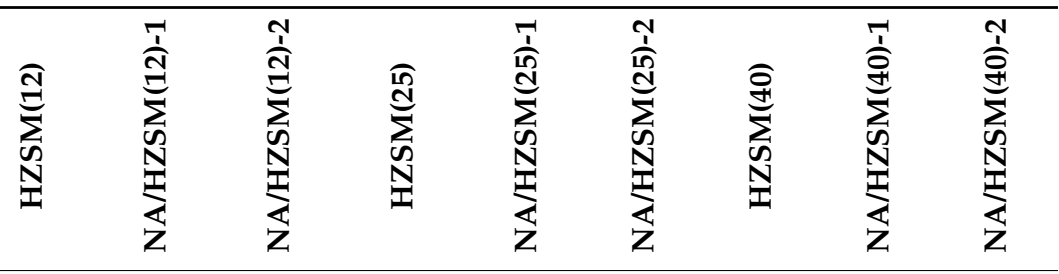

\begin{tabular}{lccccccccc}
\hline Temperature, $\mathbf{K}$ & \multicolumn{10}{c}{$\mathbf{S}_{\text {ETH }} \%$} \\
\hline 473 & 94 & 92 & 98 & 98 & 93 & 95 & 96 & 91 & 100 \\
\hline 513 & 45 & 46 & 83 & 83 & 48 & 72 & 78 & 68 & 91 \\
\hline 573 & 4 & 0 & 2 & 12 & 1 & 2 & 1 & 1 & 20 \\
\hline Temperature, $\mathbf{K}$ & & & & & $\mathbf{S}_{\text {DEE }} \%$ & & & & \\
\hline 473 & 6 & 8 & 2 & 2 & 7 & 5 & 4 & 9 & 0 \\
\hline 513 & 55 & 54 & 17 & 17 & 52 & 28 & 22 & 32 & 9 \\
\hline 573 & 96 & 100 & 98 & 88 & 99 & 98 & 99 & 99 & 80 \\
\hline
\end{tabular}

Differences were found for $\alpha_{E}, \%$ to DEE and ETH and $\mathrm{S}_{D E E / E T H}, \%: \mathrm{S}_{E T H}, \%$ at $573 \mathrm{~K}$ is significantly less for $\operatorname{HZSM}(25)$ compared to $\operatorname{HZSM}(12)$ and $\operatorname{HZSM}(40)$, but $\mathrm{S}_{D E E}, \%$ at $473 \mathrm{~K}$ for all HZSM is almost the same (Table 10). $\alpha_{E}, \%$ to DEE decreases in the row $\operatorname{HZSM}(12)>$ $\operatorname{HZSM}(25)>\operatorname{HZSM}(40)(513 \mathrm{~K})$ (Figure 14), coinciding with a decrease in the concentration of all kinds of acid sites (Table 10). HZSM(12) has the maximum concentration of strong, medium, and weak acid sites (Table 10), maximum content of Si(Al)O groups (XPS data, Table 5), physically adsorbed water and "zeolite water" with $\mathrm{OH}$ groups in the framework voids (FTIR, DSC, and XPS data, Tables 4 and 5, Figure 6). 


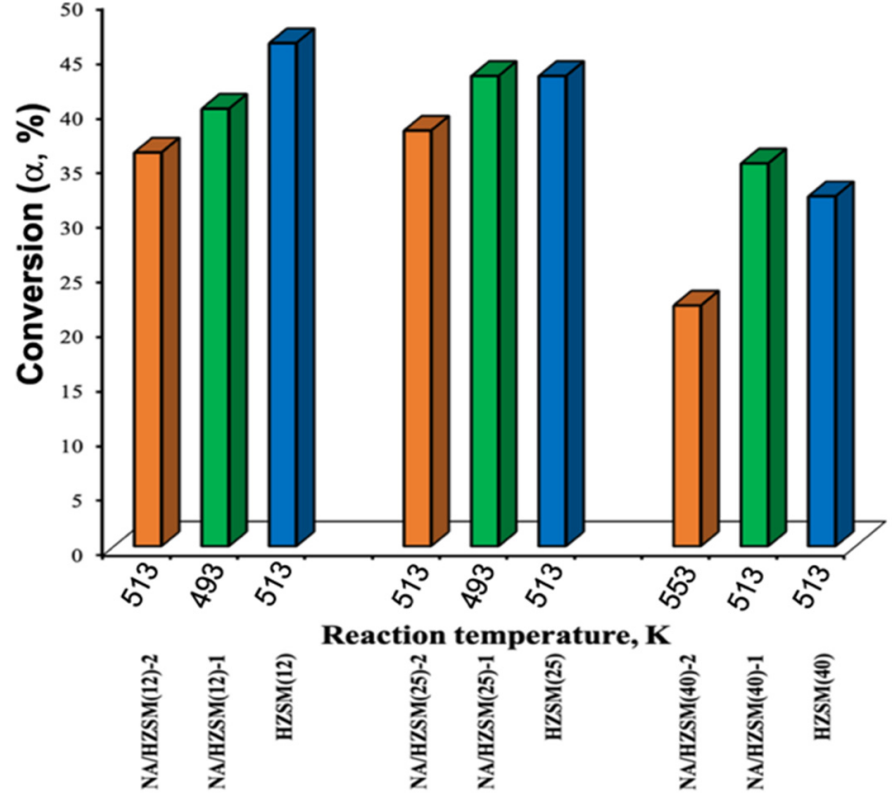

(a)

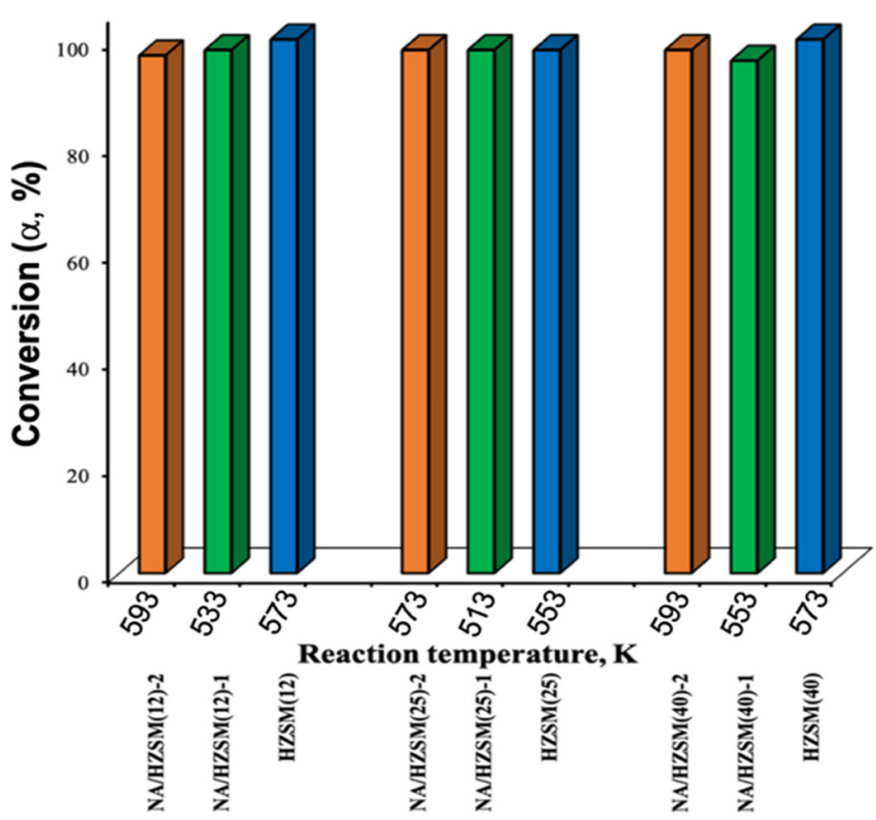

(b)

Figure 14. Conversion of ethanol $(\alpha, \%)$ to diethyl ether (a) and ethylene (b) for HZSM and NA/HZSM-1,2 (data from [16]).

$\operatorname{HZSM}(25)$ with the highest $\mathrm{S}_{D E E}, \%(513 \mathrm{~K})$ (Table 10) has maximum content of bridging hydroxyls Si-OH-Al(Fe) and terminal silanol groups Si-OH (FTIR data, Figure 6), maximum micropores volume and average pore hydraulic radius, but minimum particle size (Table S3).

All HZSM have $\alpha_{E}, \%$ comparable to ETH (Figure $\left.14 \mathrm{~b}\right)$. The highest $\mathrm{S}_{E T H}, \%$ (573 K) is for $\operatorname{HZSM}(40)$ with maximum values of mesopores volume, specific surface area, size of spherical particles associates (Table S3), minimum content of Si(Al)O groups (Table 5), bridging hydroxyls Si-OH-Al (Figure 7), physically adsorbed water and "zeolite water" with OH groups in the framework voids (Tables 4 and 5, Figure 7) and minimum concentration of medium acid sites (Table 9).

Fabrication of NA/HZSM-1 nanocomposites leads to a decrease in the reaction temperature of $E$ conversion to DEE and ETH ( $493 \mathrm{~K}$ and $553 \mathrm{~K}$ correspondingly for DEE and $E T H$, mostly in NA/HZSM(25)-1 and slightly lower in NA/HZSM(12)-1 with the maximum total acidity (Table 9 , Figures $14 \mathrm{a}$ and S3). The values of $\alpha_{E}, \%, \mathrm{~S}_{D E E}, \%$, and $\mathrm{S}_{E T H}, \%$ maintain comparable to those of initial zeolites (Table 10, Figure 14). The maximum total acidity of NA/HZSM(12)-1 and NA/HZSM(25)-1 indicates the effect of NA in the composition of nanocomposites obtained by Method $1 b$ on their acidic properties. According to $[13,41]$ on the NA surface there are Lewis acid sites, enhancing the nearby Bronsted sites, provoking an increase in the selectivity for hydrocarbons in reactions proceeding via the redox mechanism.

Synthesis of NA/HZSM-2 nanocomposites has no significant effect on catalytic activity (Table 10, Figure 14).

The catalytic activity of samples obtained is higher or comparable to the commercial NKC-03A with $\alpha_{\text {ETH }}=98 \%$ at $T=533 \mathrm{~K}$ and $S_{E T H}=98 \%$ [161] and Al-B with $S_{E T H}=92 \%$ at $T=673 \mathrm{~K}$ and $S_{D E E}=57 \%$ at $T=573 \mathrm{~K}[16,162]$.

\subsection{Titanosilicalites $\left[\mathrm{Ti}^{4+}{ }_{x} \mathrm{Si}^{4+}{ }_{12-x} \mathrm{O}_{24}\right] \times w \mathrm{H}_{2} \mathrm{O}$}

\subsubsection{Composition and Crystal Structure}

Titanosilicalites (TS; MFI) crystallize in two crystal systems: monoclinic and orthorhombic: the anhydrous orthorhombic $\left[\left(\mathrm{Ti}^{4+}{ }_{\mathrm{x}} \mathrm{Si}^{4+}{ }_{12-\mathrm{x}}\right) \mathrm{O}_{24}\right]$ phase $\left(2.6 \mathrm{wt} . \% \mathrm{TiO}_{2}\right)$ exists above $160 \mathrm{~K}$, and the monoclinic phase exists below it [163]. Cooling the sample from $170 \mathrm{~K}$ to $80 \mathrm{~K}$ leads to a decrease in the unit cell volume $\left(\mathrm{V}, \AA^{3}\right)$ from $5361.2(3)$ to $5352.5(4) \AA^{3}$, i.e., 
$\mathrm{V}, \AA^{3}$ of the monoclinic phase is smaller in comparison with the orthorhombic one, while $\mathrm{V}, \AA^{3}$ of this sample at room temperature is 5390.5(4) $\AA^{3}$ [163]. Moreover, the symmetry of titanosilicalites depends on the titanium content in the framework and the fabrication (processing) conditions (see, for example, [94]).

According to $[163,164]$, the limiting content of $\mathrm{Ti}^{4+}$ ions in TS is, correspondingly, $3.1 \mathrm{wt} . \% \mathrm{TiO}_{2}$ and $4.2 \mathrm{wt} . \% \mathrm{TiO}_{2}$. The difference in values according to various publications can be explained by methods and obtaining conditions of TS $[68,115,165]$. It is obvious that the real compositions of titanosilicalites should not be lower than $\mathrm{Si} / \mathrm{Ti} \sim 20$ for obtaining pure and well-crystallized TS. High concentration of titanium atoms leads to the formation of anatase as a secondary phase. The maximum titanium doping level in TS is around $2.5 \mathrm{wt} . \%(\mathrm{Si} / \mathrm{Ti}=40)[117,163]$. The maximum volume of the unit cell $\left(\mathrm{V}(\mathrm{x}), \AA^{3}\right)$ lies in the range of 5389-5396.5 $\AA^{3}$ irrespective of the maximum Ti content in TS [117].

The objects of our study were: three commercial samples TS-1, TS-2, and TS-3 from different batches (their fabrication conditions were not known, and the $\mathrm{TiO}_{2}$ content in the sample (3.1 wt.\%) was known only for TS-2 and TS-3); TS-4 sample obtained by the hydrothermal method (Table S1); and the same samples, but annealed at $348 \mathrm{~K}$ for $2 \mathrm{~h}$ (TS-1(348), TS-2(348), TS-3(348), and TS-4(348) samples, Table 11) and at $773 \mathrm{~K}$ for $2 \mathrm{~h}$ (TS-3(773) and TS-4(773) samples). 
Table 11. Crystallographic data of TS-1, TS-2, TS-3, TS-4, TS-1(348), TS-2(348), TS-3(348), and TS-4(348) (data from [33,34]).

\begin{tabular}{|c|c|c|c|c|c|c|c|c|}
\hline \multirow{2}{*}{ Sample } & \multicolumn{8}{|c|}{ Initial Composition $\left[\left(\mathrm{Ti}^{4+}{ }_{x} \mathrm{Si}^{4+}{ }_{12-x}\right) \mathrm{O}_{24}\right] \times w \mathrm{H}_{2} \mathrm{O}$} \\
\hline & TS-1 * & TS-1(348) * & TS-2 * & TS-2(348) * & TS-3* & TS-3(348)* & TS-4** & TS-4(348)** \\
\hline Scherrer size, nm & 101.7 & 99.2 & 55.7 & 75.1 & 66.3 & 64.9 & - & - \\
\hline Microstrains, \% & 0.344 & 0.354 & - & 0.311 & 0.22 & 0.14 & - & - \\
\hline System, sp. gr., Z & \multicolumn{8}{|c|}{ Orthorombic, Pnma (62), 8} \\
\hline $\mathrm{a}, \AA$ & $20.0995(3)$ & $20.0998(3)$ & $20.1061(8)$ & $20.1087(5)$ & $20.1086(8)$ & $20.1110(8)$ & $20.0526(11)$ & $20.0518(12)$ \\
\hline $\mathrm{b}, \AA$ & $19.9245(3)$ & 19.9237(3) & $19.9425(8)$ & $19.9392(5)$ & 19.9408(9) & 19.9423(8) & $19.9323(11)$ & $19.9318(11)$ \\
\hline c, $\AA$ & $13.4105(2)$ & $13.4096(2)$ & $13.4225(6)$ & $13.4184(4)$ & $13.4225(7)$ & $13.4193(6)$ & $13.4069(9)$ & $13.4065(9)$ \\
\hline$\lambda, \AA$ & 0.7836 & 0.7836 & 0.79351 & 0.8 & 0.8 & 0.8 & $0.354345(3)$ & $0.354345(3)$ \\
\hline $2 \theta$ range, measured & $0.33-37.32$ & $0.33-37.32$ & $1.02-59.82$ & $0.97-60.34$ & $0.99-60.28$ & $0.99-60.28$ & $1.000-23.000$ & $1.000-23.000$ \\
\hline $2 \theta$ range, used & $3.18-33.80$ & $3.18-33.80$ & $2.26-33.60$ & $2.48-34.82$ & $3.04-35.90$ & $3.01-35.59$ & - & - \\
\hline Number of points & 7398 & 7398 & 5881 & 5869 & 5875 & 5875 & - & - \\
\hline Number of refined parameters & 154 & 154 & 144 & 154 & 154 & 154 & - & - \\
\hline$R_{p} / w R_{p}$ & $1.75 / 2.36$ & $1.78 / 2.34$ & $2.08 / 2.75$ & $1.47 / 1.87$ & $2.13 / 2.77$ & $2.81 / 3.54$ & $0.043 / 0.058$ & $0.042 / 0.054$ \\
\hline GOF & 0.87 & 0.99 & 1.09 & 0.72 & 0.77 & 1.13 & 9.270 & 6.938 \\
\hline $\mathrm{R}_{\text {Bragg }}$ & 1.90 & 2.56 & 1.90 & 1.98 & 2.86 & 3.39 & 0.017 & 0.019 \\
\hline Number of water molecules & 6.5 & 5.0 & 6.0 & 7.5 & 7.5 & 7.5 & $1.614(11)$ & $1.645(12)$ \\
\hline
\end{tabular}

*-XRPD (Kurchatov Synchrotron Radiation Source), **_ESRF (Grenoble, France). 
The presence of silicon-containing oxygenous formations (marked with an oval on Figure 15) makes it impossible to correctly determine the titanium content in TS-1, TS-2, and TS-3 frameworks by elemental methods of analysis.

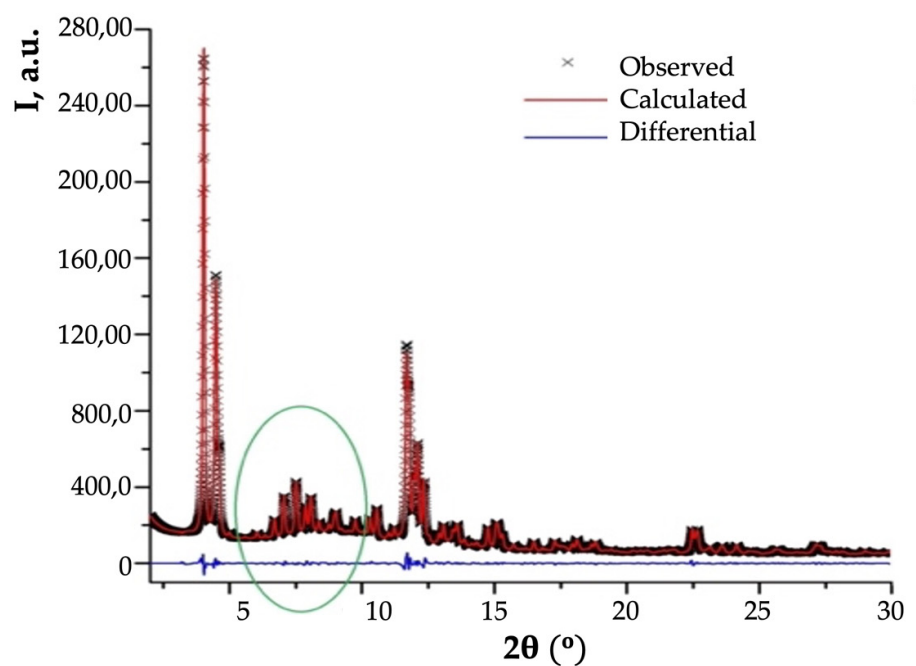

(a)

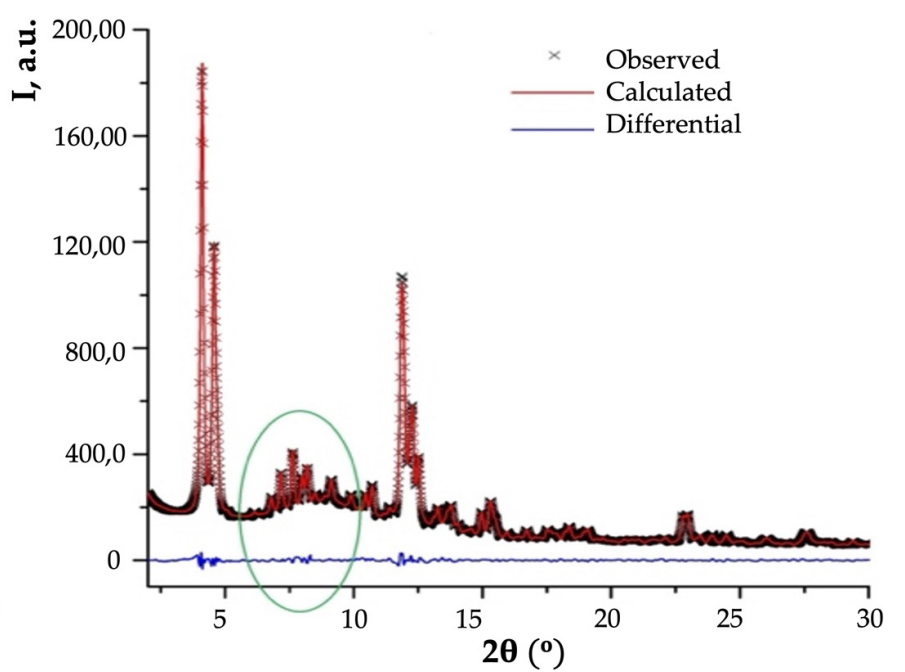

(b)

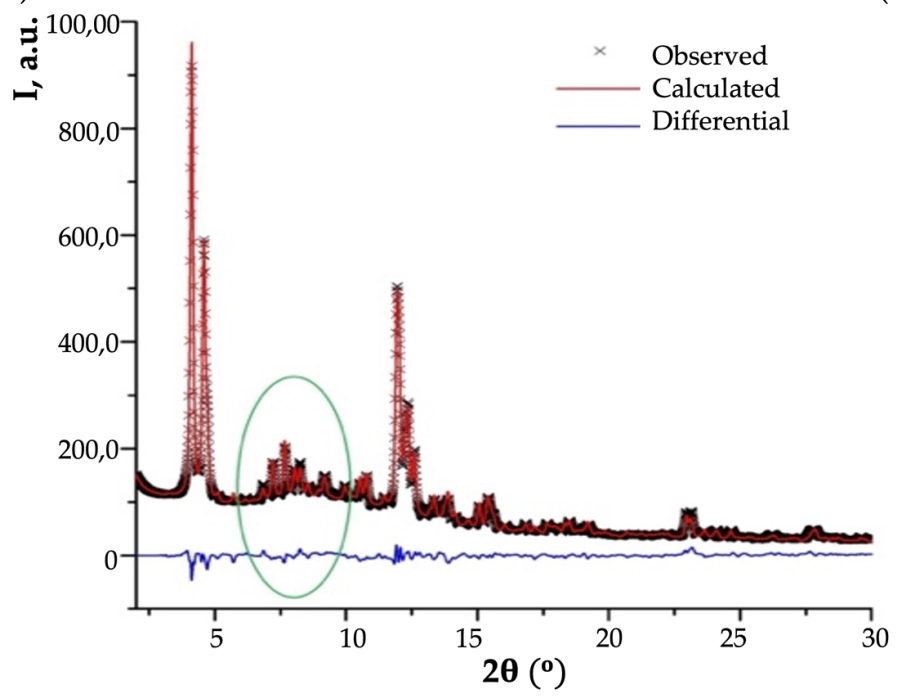

(c)

Figure 15. Final profile fit obtained for sample TS-1 (a), TS-2 (b), and TS-3 (c), (adapted from [33,34]).

The maximal intensity of amorphous region in X-ray diffraction pattern (XRPD) of the studied samples (Figure 15 ) is $\sim 5.0 \%$ and $\sim 4.5 \%$ of most intense peak for TS-2 and TS-3, $\sim 2.4 \%$ for TS-1, and the intensity for other samples (TS-1(348), TS-2(348), and TS-3(348)) is much lower. This fact means than amorphous formations decompose after performed thermal treatment of TS-1, TS-2, and TS-3 samples. In this regard, Bragg peaks of impurity anatase are absent in all diffraction patterns.

Analysis of TS-4 titanosilicalite X-ray patterns (Figure 16a) and crystallographic data (Table 11) shows that the amorphous region responsible for silicon-containing oxygenous formations is absent, but tetrapropylammonium hydroxide (which is used in the synthesis of ZSM-5 zeolites) presents in the framework voids. 


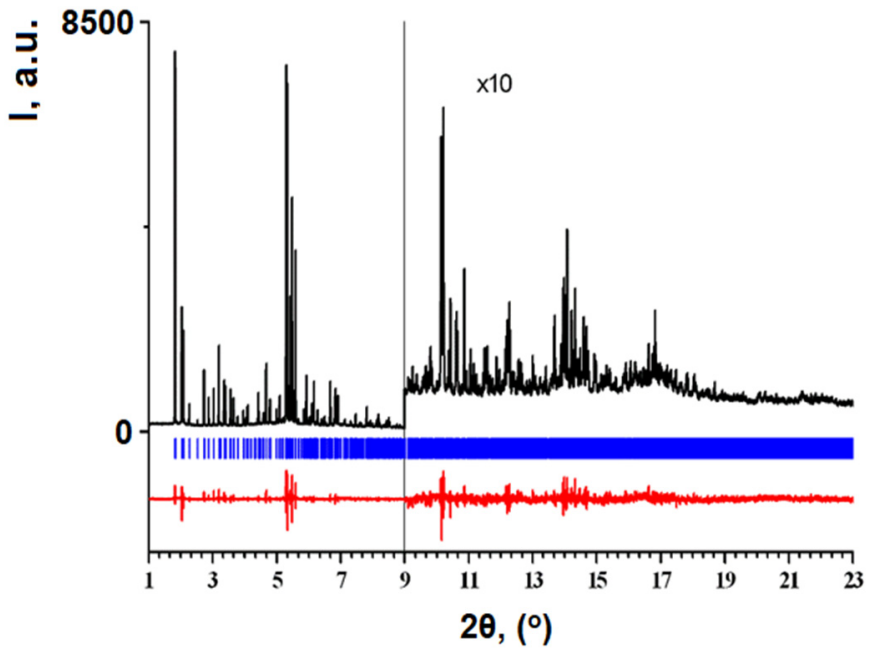

(a)

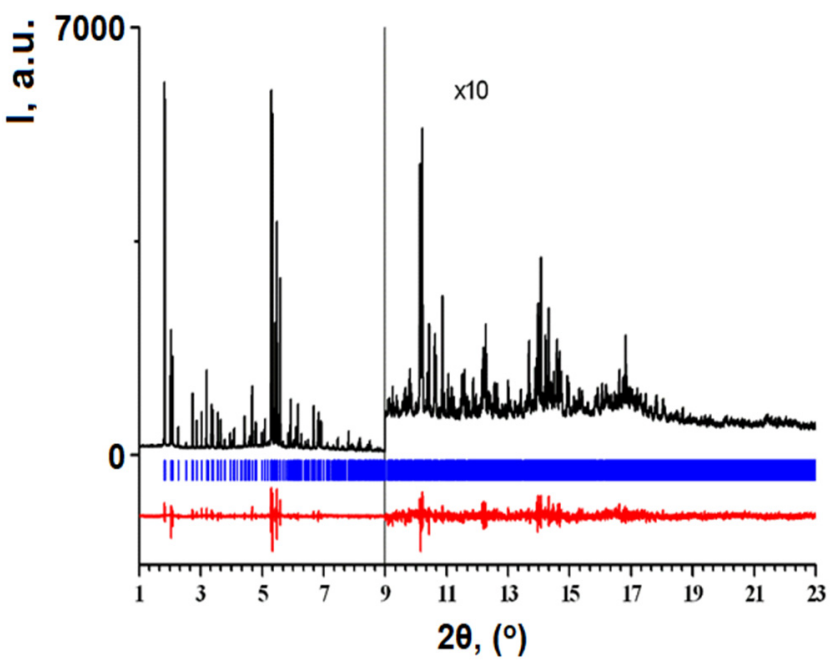

(b)

Figure 16. Final profile fit obtained for TS-4 (a) and TS-4(348) (b) samples (adapted from [34]).

The full-profile Rietveld method data analysis (Table 11, Figure 15) revealed that both commercial TS-1, TS-2, and TS-3 and synthesized by us TS-4 titanosilicalites crystallize in orthorhombic symmetry but judging by the unit cell volume their compositions are different: $\mathrm{Ti}^{4+}$ ions content is higher in TS- 3 and TS- 2 compared to TS- 1 and TS- 4 . This ratio of titanium and silicon atoms in TS-1, TS-2, and TS-3 and TS-4 (TS-4 > TS- $1>$ TS-3 > TS-2) is confirmed by FTIR spectroscopy data (Figure 17).

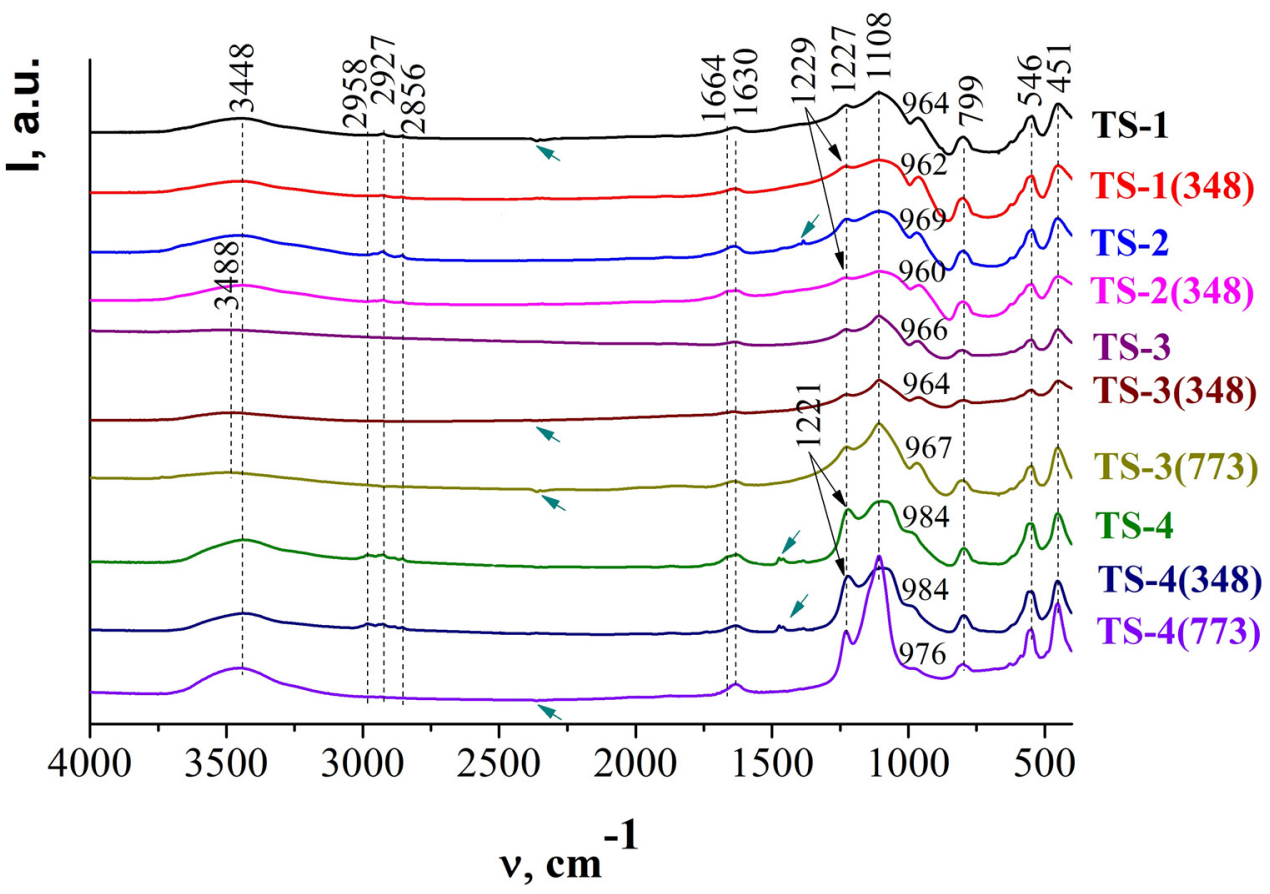

Figure 17. FTIR spectra of TS samples in coordinates Intensity (arbitrary units, a.u.) —absorption frequency $\left(\mathrm{v}, \mathrm{cm}^{-1}\right)$ (black arrows - TS asymmetric stretching vibration; green arrows - organic template (TPAOH) residues groups in zeolite channels) (adapted from [33,34]).

Antisymmetric stretching vibrations inside $\mathrm{TO}_{4}$ tetrahedra are characterized by the band at $~ 1108 \mathrm{~cm}^{-1}$, which intensity is approximately identical to TS- $1\left(\mathrm{I}_{1108 \mathrm{~cm}}{ }^{-1}=0.2509\right.$

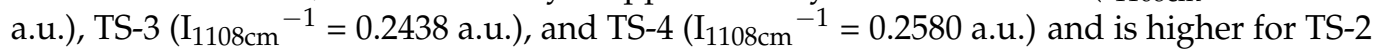




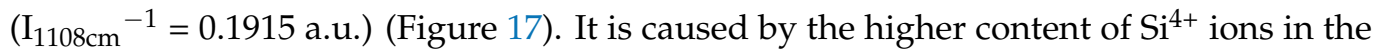
TS- 1 and TS-4 than in the TS-2, TS-3 structure. $2 \theta,\left({ }^{\circ}\right)$.

The band at $~ 960$ to $970 \mathrm{~cm}^{-1}$ (Figure 17) in FTIR spectra of titanium silicalites is responsible for the titanium content in the TS framework [165]. This band is currently considered as the "fingerprint" of Ti-containing zeolites and is not observed in pure silica and aluminosilicalites (Figure 6). Its intensity decreases in the row TS-2 $\left(\mathrm{I}_{969 \mathrm{~cm}^{-1}}=0.144\right.$

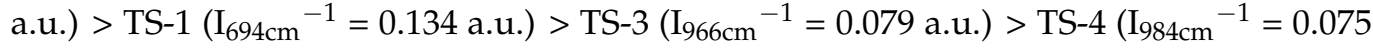
a.u.), i.e., the content of Ti atoms is higher in TS-2.

Judging by the unit cells volumes (Table 11) the compositions of TS- 1 and TS-1(348), TS-2 and TS-2(348) are almost the same, although the unit cell volume of TS-2 is slightly larger compared to TS-2(348) (Table 11). The unit cell volume of the synthesized TS-4 (Table 11), the X-ray pattern of which was recorded on another radiation source (ESRF), is less than the unit cell volumes of commercial TS-1, TS-2, and TS-3 (XRPD source), but the tendency of a decrease in the unit cell volume of TS- 4 after annealing at $348 \mathrm{~K}$ for $2 \mathrm{~h}$ can be traced (Table 11).

Annealing of TS samples at $\mathrm{T}=348 \mathrm{~K}$ decreases contents of physically bound adsorbed water (TS-2 >> TS-2(348), TS-3 >> TS-2(348), TS-1 > TS-1(348)), and water in the framework cavities (TS-1 >> TS-1(348), TS-2 $\approx$ TS-2(348), TS-2 > TS-2(348)), except for TS-4 in which the content of physically bound adsorbed water with $\mathrm{OH}$ groups and water in the framework cavities increases (Table 12, Figure S7). 
Table 12. Correspondence of peaks $(T, K)$ in the DSC thermograms to possible thermal processes (data from $[33,34]$ ).

\begin{tabular}{|c|c|c|c|c|c|c|c|c|c|c|}
\hline KERRYPNX & TS-1 & TS-1(348) & TS-2 & TS-2(348) & TS-3 & TS-3(348) & TS-4 & TS-4(348) & TS-4(773) & Thermal Process \\
\hline \multicolumn{11}{|c|}{ First Temperature Scanning } \\
\hline $\mathrm{T}, \mathrm{K}$ & 344.15 & - & 342.85 & - & 342.85 & - & - & - & - & \multirow{2}{*}{ Removal of physically sorbed water } \\
\hline $\mathrm{H}, \mathrm{J} / \mathrm{g}$ & -71.48 & - & -231.9 & - & -208.3 & - & - & - & - & \\
\hline $\mathrm{T}, \mathrm{K}$ & - & 355.25 & - & 344.35 & - & 340.75 & 383.35 & 347.25 & 346.05 & \multirow{2}{*}{$\begin{array}{l}\text { Removal of physically sorbed water } \\
\text { with OH groups (constitution water) }\end{array}$} \\
\hline $\mathrm{H}, \mathrm{J} / \mathrm{g}$ & - & -62.51 & - & -162.2 & - & -104.7 & -30.8 & -42.76 & -89.02 & \\
\hline $\mathrm{T}, \mathrm{K}$ & - & - & - & - & - & - & - & 458.45 & - & $\begin{array}{l}\text { Decomposition of TPA+, which is } \\
\text { physically adsorbed on the particle } \\
\text { external surface }\end{array}$ \\
\hline $\mathrm{T}, \mathrm{K}$ & - & - & - & - & - & - & 663.05 & 657.45 & - & \multirow{4}{*}{$\begin{array}{l}\text { Decomposition of TPA+ tightly filled in } \\
\text { the pore channel of the zeolite } \\
\text { framework }\end{array}$} \\
\hline $\mathrm{H}, \mathrm{J} / \mathrm{g}$ & - & - & - & - & - & - & -9.975 & -10.056 & - & \\
\hline $\mathrm{T}, \mathrm{K}$ & - & - & - & - & - & - & 668.55 & 668.45 & - & \\
\hline $\mathrm{H}, \mathrm{J} / \mathrm{g}$ & - & - & - & - & - & - & -53.426 & -44.809 & - & \\
\hline $\mathrm{T}, \mathrm{K}$ & - & - & - & - & - & - & 694.55 & 694.45 & 705.55 & \multirow{4}{*}{$\begin{array}{l}\text { Desorption of "zeolite water" with } \mathrm{OH} \\
\text { groups from the voids in the framework }\end{array}$} \\
\hline $\mathrm{H}, \mathrm{J} / \mathrm{g}$ & - & - & - & - & - & - & -32.116 & -32.134 & -1.731 & \\
\hline $\mathrm{T}, \mathrm{K}$ & 781.15 & 770.95 & 772.15 & 771.15 & 707.85 & 708.25 & 734.05 & 732.45 & 728.55 & \\
\hline $\mathrm{H}, \mathrm{J} / \mathrm{g}$ & -4.48 & -1.06 & -3.53 & -3.45 & -14.21 & -11.81 & -88.766 & -90.146 & -0.710 & \\
\hline $\mathrm{T}, \mathrm{K}$ & 355.05 & 357.45 & 335.35 & 352.75 & 356.25 & 335.95 & - & 404.05 & - & \multirow{2}{*}{$\begin{array}{l}\text { Removal of residual weakly bound } \\
\text { water with } \mathrm{OH} \text { groups }\end{array}$} \\
\hline $\mathrm{H}, \mathrm{J} / \mathrm{g}$ & -2.05 & -11.06 & -56.58 & -12.55 & -5.46 & -52.61 & - & -12.15 & - & \\
\hline $\mathrm{T}, \mathrm{K}$ & - & - & - & - & - & - & - & 530.85 & - & \multirow{2}{*}{$\begin{array}{l}\text { Decomposition of TPA+ residues, which } \\
\text { is physically adsorbed on the particle } \\
\text { external surface }\end{array}$} \\
\hline $\mathrm{H}, \mathrm{J} / \mathrm{g}$ & - & - & - & - & - & - & - & -0.1551 & - & \\
\hline $\mathrm{T}, \mathrm{K}$ & 719.55 & 735.15 & 739.55 & 743.15 & 719.85 & 717.25 & 735.65 & 736.75 & 720.15 & \multirow{2}{*}{$\begin{array}{l}\text { Removal of residual strongly bound } \\
\text { water }\end{array}$} \\
\hline $\mathrm{H}, \mathrm{J} / \mathrm{g}$ & -0.71 & -0.71 & -3.51 & -2.01 & -8.396 & -8.328 & -0.926 & -2.479 & -8.573 & \\
\hline
\end{tabular}


In the TS- 1 structure, the silicate module $(\mathrm{Si} / \mathrm{Ti}=53(1))$ was found when refining occupancy of T2, T6, and T10 sites (Table 13), i.e., exactly in defective silicon positions. For $\mathrm{TS}-2$, the silicate module turned out to be $\mathrm{Si} / \mathrm{Ti}=35$ with titanium atoms in positions $\mathrm{T} 8$, T10 (coincides with the data of [118]) and T5 (in order of decreasing titanium content). If we take into account the standard deviation $3 \sigma$ for site occupancy (Table 13), $\mathrm{To} \mathrm{Si} / \mathrm{Ti}=47(1)$, i.e., titanium atoms are absent in T5 position. Despite the good agreement between the observed and calculated X-ray diffraction patterns for TS- 1 and TS-2 (Figure 13), it is likely that a large fraction of the amorphous component in TS-2 did not allow an increase in the accuracy of the structural parameters determining, including the silicon positions occupation.

Table 13. Occupation of tetrahedral sites by $\mathrm{Ti}^{4+}$ ions.

\begin{tabular}{|c|c|c|c|c|c|c|c|c|c|c|c|c|}
\hline \multicolumn{13}{|c|}{$T$-Sites } \\
\hline & T1 & T2 & T3 & $\mathrm{T} 4$ & T5 & T6 & T7 & T8 & T9 & T10 & T11 & T12 \\
\hline TS-1 & - & $0.046(12)$ & - & - & - & $0.115(11)$ & - & - & - & $0.059(13)$ & - & - \\
\hline TS-2 & - & - & - & - & $0.08(3)$ & - & - & $0.17(2)$ & - & $0.08(2)$ & - & - \\
\hline TS-3 & - & $0.055(15)$ & - & - & - & - & - & $0.023(7)$ & - & $0.135(15)$ & - & $0.050(17)$ \\
\hline TS-4 & $0.081(9)$ & - & - & - & - & $0.074(10)$ & - & - & - & - & - & - \\
\hline TS-4(348) & $0.090(10)$ & - & - & - & - & $0.077(10)$ & - & - & - & - & - & - \\
\hline
\end{tabular}

In the TS-3 structure with the same titanium content as in the TS-2 sample, $\mathrm{Ti}^{4+}$ ions occupy other sites in the framework: T2, T9 (unlikely, considering 3б), T10, T12 (Si/Ti $=45(1)$ (Table 13) or $\mathrm{Si} / \mathrm{Ti}=48(1)$ taking into account the standard deviation of $3 \sigma$ for sites occupancy (titanium atoms are absent in the T9 site). For TS-4 and TS-4(348) with tetrapropylammonium hydroxide in the framework voids an average value of $\mathrm{Si} / \mathrm{Ti}=73.5$ was found [34].

In TS-1, structure titanium atoms are located in 5-, 6-, and 10-membered rings (T2, T6, and T10 sites) (Table 13), straight channels (T6, T10, and T2 sites) (Figure 18a, Table 13), and sinusoidal ones (T6, T2, and double site T10) (Figure 18b, Table 13). In the TS-2 structure titanium atoms occupy sites in 5-, 6-, and 10-membered rings (T8 and T10) (Figure 18a) and sinusoidal channels (T10 double site) (Figure 18b, Table 13). In contrast to the TS-2 structure, in the TS-3 structure titanium ions are located in sinusoidal channels not in one (T10), but in two double positions T10 and T12. In TS-4 structure titanium atoms occupy sites in 5-, 6-, and 10-membered straight and sinusoidal channels (T1 and T6) (Figure 18, Table 13) [33,34].

These results do not contradict the generalized structural data of [166]: $\mathrm{Ti}^{4+}$ titanium ions occupy T10 (67\%), T8 and T11 (50\%), and T12 (42\%) in MFI type TS structure. However, the titanium content and its distribution over the structural sites depend not only on the sample fabrication and processing conditions, but, to a greater extent, on the strategy for composition determining by X-ray and neutron diffraction methods. In [34], it was assumed that the correct strategy of TS crystal structure refining is the substantiated minimization of the refining parameters number and their residence in narrow fixed limits for cations as well as a varying of the occupancy of tetrahedral sites only to sites, which have the pronounced tendency to such behavior. 


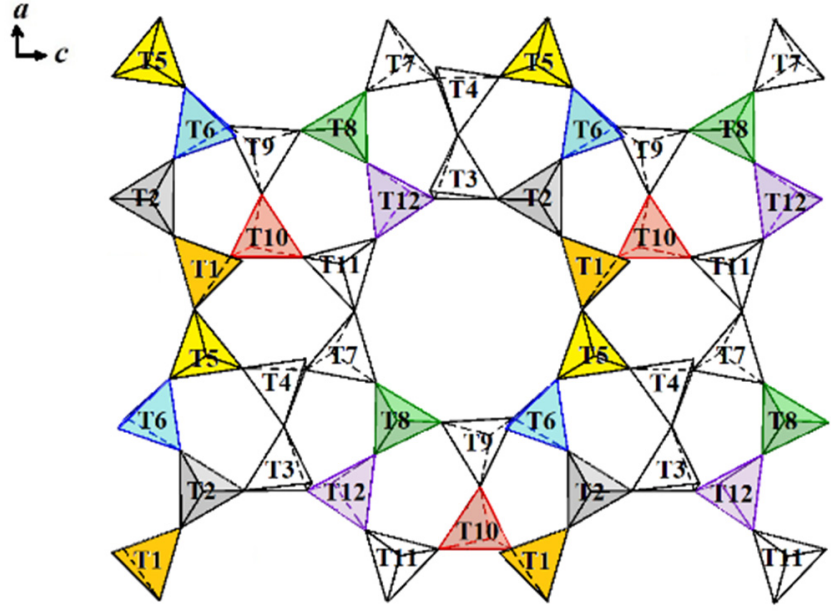

(a)

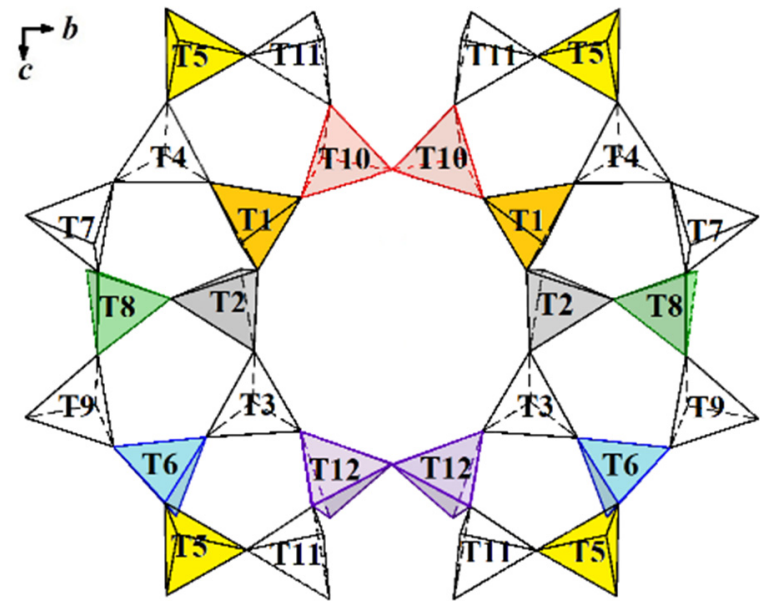

(b)

Figure 18. Combination of rings along $<010>$-rectilinear channels (a) and $<100>$ - sinusoidal channels $(\mathbf{b})$. Sites with $\mathrm{Ti}^{4+}$ ions in TS-1, TS-2, TS-3, and TS-4 structures are marked with different colors: orange-TS-4, yellow-TS-2, purple-TS-3, grey-common sites of TS-1 and TS-3, blue-common sites of TS-1 and TS-4, green-common sites of TS-2 and TS-3, pink-common sites of TS-1, TS-2, and TS-3.

\subsubsection{Local Structure}

XANES spectroscopy is widely employed to discriminate among four-, five-, and six-fold coordinated $\mathrm{Ti}^{4+}$ species as the local coordination strongly influences the intensity and, appreciably, the position of the 1s-3pd electronic transition [167-169]. Ti K-edge EXAFS and XANES data are shown in Figure 19.

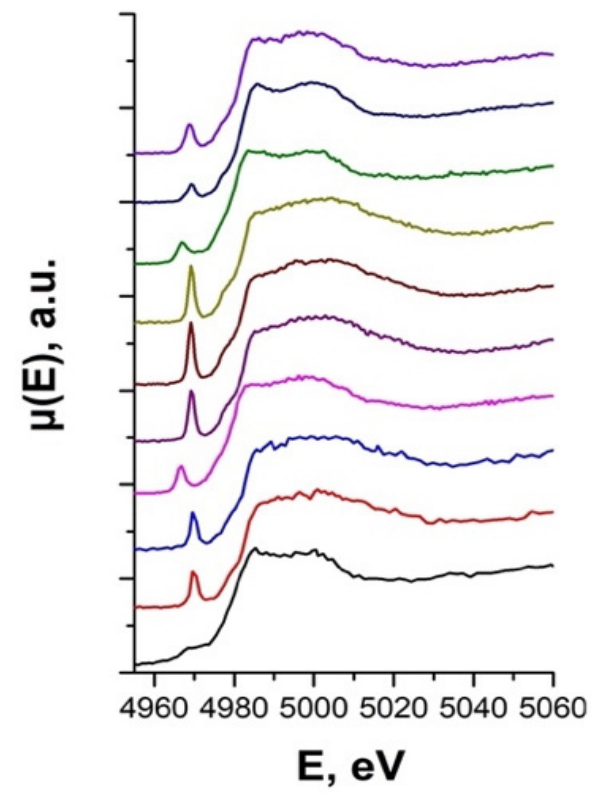

(a)

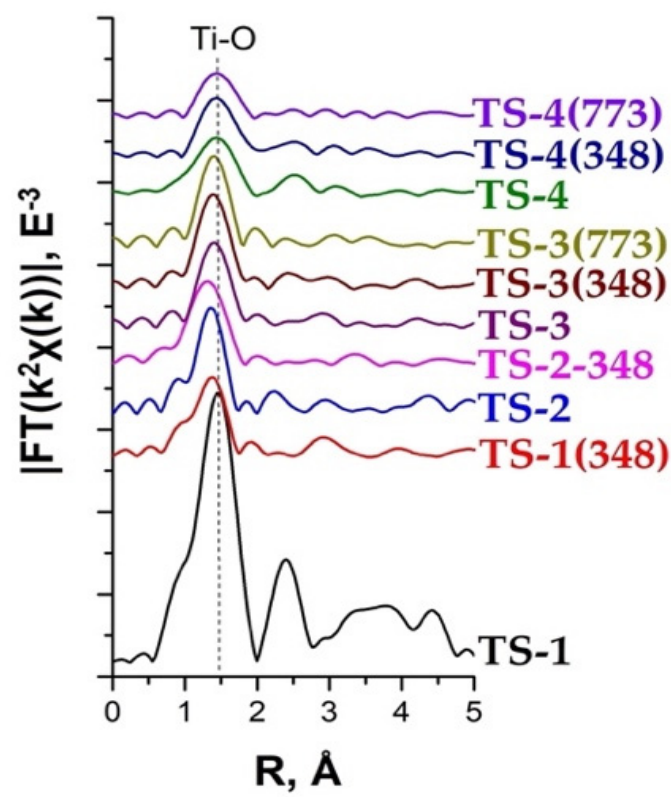

(b)

Figure 19. Ti K-edge XANES (a) and EXAFS (b) data for TS-1, TS-1(348), TS-2, and TS-2(348) samples (adapted from $[33,34])$.

XANES data reveal a sharp pre-edge maximum (1s-3d) for all the samples, which indicates the tetrahedral coordination of Ti (Figure 19a). A broader maximum for TS-1 can be either due to the local structure disordering or to the presence of multiple types of $\mathrm{Ti}$ coordination in the sample [33]. The intensity of the pre-edge maximum is higher for TS-3 
series, which indicates more ordered local structure of these samples compared to TS- 1 and TS-4 (Figure 19a).

EXAFS spectroscopy plays a determining role in understanding the local environment and the reactivity of Ti in the Ti-silicalite system. The results of single-sphere EXAFS fit are shown in Table 14.

Table 14. Results of EXAFS modeling $\left(\mathrm{R}_{\mathrm{Ti}-\mathrm{O}}, \AA\right.$ is the Ti-O interatomic distance, $\sigma$ is the Debye-Waller factor, $\mathrm{CN}$ - coordination number, and $\mathrm{R}_{\mathrm{f}}$ is the convergence factor). The first coordination sphere $(\mathrm{R}=1-2 \AA)$ (Data from $[33,34])$.

\begin{tabular}{ccccc}
\hline Sample & CN Ti & $\mathbf{R}_{\text {Ti-O }}, \AA$ & $\mathbf{\sigma}^{2}, \AA^{\mathbf{2}}$ & $\mathbf{R}_{\mathbf{f}}, \boldsymbol{\%}$ \\
\hline TS-1 & 4.9 & 1.93 & 0.0066 & 1.7 \\
TS-1(348) & 3.6 & 1.84 & 0.0015 & 0.7 \\
TS-2 & 4.5 & 1.82 & 0.0001 & 1.5 \\
TS-2(348) & 4.4 & 1.82 & 0.0004 & 0.1 \\
TS-3 & 5.0 & 1.83 & 0.0011 & 0.5 \\
TS-3(348) & 5.1 & 1.81 & 0.0008 & 0.9 \\
TS-3(773) & 5.3 & 1.90 & 0.0085 & 2.0 \\
TS-4 & 4.6 & 1.94 & 0.0035 & 0.5 \\
TS-4(348) & 4.6 & 1.95 & 0.0032 & 0.8 \\
TS-4(773) & 3.8 & 1.92 & 0.0044 & 0.1 \\
\hline
\end{tabular}

No significant difference was found between coordination numbers of TS samples, (mostly due to the error in CN determination), except for TS-1(348) and TS-4(773), whose values of $\mathrm{CN}$ are more and less, respectively, compared to other samples (Table 14). However, without taking into account $\mathrm{CN}$ determination error, there is a tendency for $\mathrm{CN}$ decrease in the row TS-3(773) $\approx$ TS-3(348) $\approx$ TS-3 $\approx$ TS- $1>$ TS- $4=$ TS- $4(348) \approx$ TS- $2 \approx$ TS-2(348) > TS-4(773) $\approx$ TS-1(348) (Table 14). In this row, according to DSC (Table 12), the content of framework water molecules together with $\mathrm{OH}$ groups decreases, with the exception of TS-4, TS-4(348), and TS-4(773), the cavities of which, in addition to water, contain a large amount of TPAOH.

It is a matter of fact that a pure tetrahedral coordination is present only in outgassed TS, completely deprived of the adsorbed water acting as an additional ligand. For highly hydrated samples, an increase in the coordination from four (tetrahedral) up to six (octahedral) (Figure 20a) passing through a coordination of five (semi-octahedron or trigonal bipyramidal) (Figure 20b,c), according to the extent of hydration, is observed [170].

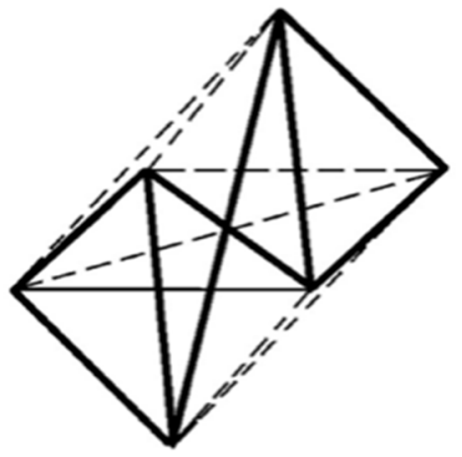

(a)

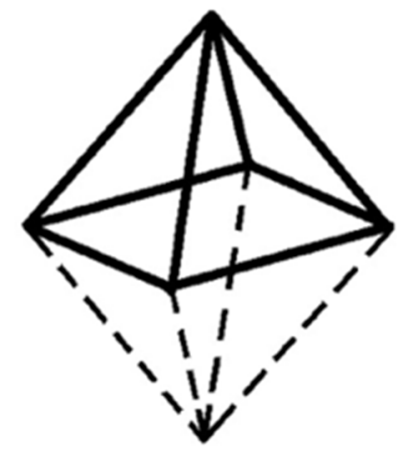

(b)

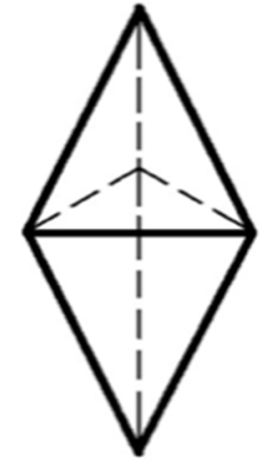

(c)

Figure 20. Rearrangement of two tetrahedra into an octahedron (CN 6) (a), a semi-octahedron (CN 5) (b), and a trigonal bipyramid (c).

This can be interpreted with the existence of two different structural situations for $\mathrm{Ti}^{4+}$ ions in the studied structures [171]: a [Ti( $\left.\left(\mathrm{OSiO}_{3}\right)_{4}\right]$ "closed site" corresponding to Ti in tetrahedral coordination $(\mathrm{CN} \mathrm{Ti}=4)($ Figure 21a) in the framework, and a defective 
$\left[(\mathrm{OH}) \mathrm{Ti}\left(\mathrm{HOSiO}_{3}\right)\left(\mathrm{OSiO}_{3}\right)_{3}\right]$ or $\left[(\mathrm{OH})_{2} \mathrm{Ti}\left(\mathrm{HOSiO}_{3}\right)\left(\mathrm{OSiO}_{3}\right)_{3}\right]$ "open site" in which $\mathrm{Ti}$ is $\mathrm{CN}$ $\mathrm{Ti}=5$ or 6 (Figure 21b).

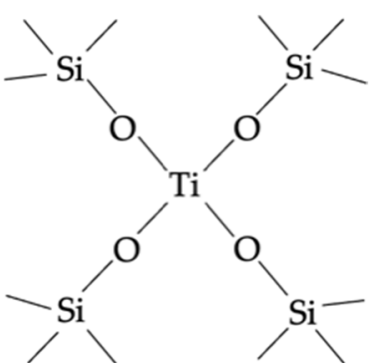

(a)

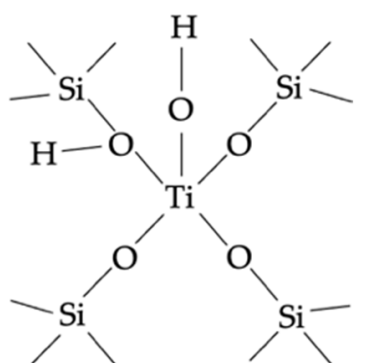

(b)

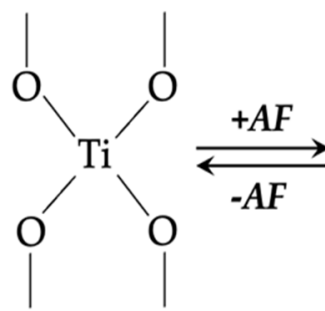<smiles>CO[Al](OC)(OC)OC</smiles><smiles>CO[Al]([AlH2])(OC)(OC)(OC)OC</smiles>

(c)

Figure 21. General view of the 'closed' $\mathrm{Ti}(\mathrm{OSi})_{4}$ site $(\mathbf{a})$, defective 'open' $\mathrm{Ti}(\mathrm{OSi})_{3}(\mathrm{OH})$ site $(\mathbf{b})$ and rearrangement of the titanium atoms coordination environment (AF-atomic formations) (c). The schemes on (a) and (b) correspond to the structures evidenced by dotted and full arrows in Figure $20 \mathrm{~b}$.

The CN $~ 5.0$ in TS-1, TS-3, TS-3(348) and TS-3(773) structures and CN $\sim 4.5$ in TS-2, TS-2(348), TS-4 and TS-4(348) structures (Table 14) reflect the presence of a fraction of titanium atoms having slightly more than four oxygen atoms in the first coordination sphere owing to the interaction of tetracoordinated Ti in an "open site" with the oxygen atoms of a silanol in the nearness (Figure 21b). It is not excluded that $\mathrm{CN} \mathrm{Ti}<4.0$ in TS-1(348) and TS-4(773) structures (Table 14) is conditioned by the $\left[\mathrm{Ti}\left(\mathrm{OSiO}_{3}\right)_{3}\right]$ "closed site" of $\mathrm{Ti}$ in defective tetrahedral coordination.

The model reported in Figure 21c based on the ability of the fourfold coordinated Ti species to increase their coordination sphere by interaction with adjacent atomic formations (AF, which can be precursor ions, $\mathrm{OH}$, water) is able to explain why a coordination number higher than $\mathrm{CN}=4$ has been observed for dehydrated TS, in particular, TS-1, TS-3, TS-3(348), TS-3(773), TS-2, TS-2(348), TS-4, and TS-4(348) (Table 14).

It is evident that only a defect-free TS, calcined and dehydrated, containing all perfect or "closed" $\mathrm{Ti}(\mathrm{OSi})_{4}$ sites, will exhibit a theoretical value of $\mathrm{CN}=4.0$ (Figure 21a) [114]. The EXAFS results agree with the FTIR spectroscopy data, notably, the content of framework water with internal OH groups decrease in the row TS-3 > TS-3(348) >> TS- $1>$ TS- $2 \approx$ TS-2(348) > TS-1(348). It is accompanied by a decrease in the content of internal OH groups, i.e., with the passage from "open" sites of "defect" titanium silicalite (vacancies in the silicon site are compensated by terminal silanol $\mathrm{OH}$ groups in oxygen sites) to closed sites.

Thus, the relative fraction of defective "open" Ti $(\mathrm{OSi})_{3}(\mathrm{OH})$ sites is higher at low $x$ values, i.e., TS-4 $(\mathrm{Si} / \mathrm{Ti}=73.5)>\mathrm{TS}-1(\mathrm{Si} / \mathrm{Ti}=53)>\mathrm{TS}-2(\mathrm{TS}-3)(\mathrm{Si} / \mathrm{Ti} \sim 47)$. Moreover, defective sites have four "chemically bonded" oxygen atoms, three bridging Ti with three different $\mathrm{Si}$ framework atoms and one hosting the titanol (Figure 21b). In this case, the insertion of a fifth oxygen of the silanol, formed in the adjacent $\mathrm{Si}$ center when the Ti-O-Si bridge (Figure 21b) is broken, is expected [114]. So, a CN = 5 is consequently expected in an ideal EXAFS measurement performed on a TS-1 sample containing only open sites. This means that the presence of a relative fraction $y$ of open sites and of 1.0-y of closed sites, would give rise to $\mathrm{CN}=4.0+y$, being $0 \leq y \leq 1.0$, in an ideal EXAFS measurement.

\subsubsection{Catalytic Properties}

Three catalytic processes were considered as an example: allyl chloride $\left(A C, \mathrm{C}_{3} \mathrm{H}_{5} \mathrm{Cl}\right)$ epoxidation $(\mathrm{T}=303 \mathrm{~K})$, ethanol $\left(E, \mathrm{C}_{2} \mathrm{H}_{5} \mathrm{OH}\right)$ conversion $(\mathrm{T}=473-673 \mathrm{~K})$, and propane $(P$, $\left.\mathrm{C}_{3} \mathrm{H}_{8}\right)$ conversion $(\mathrm{T}=298-1145 \mathrm{~K})$ to reveal the characteristics of titanosilicalites.

AC epoxidation to epichlorohydrin $\left(E C H, \mathrm{C}_{3} \mathrm{H}_{5} \mathrm{ClO}\right)$ proceeds according to reaction 17 .

$$
\mathrm{C}_{3} \mathrm{H}_{5} \mathrm{Cl}+\mathrm{H}_{2} \mathrm{O} \rightarrow \mathrm{C}_{3} \mathrm{H}_{5} \mathrm{ClO}+\mathrm{H}_{2} \mathrm{O},
$$


The study results of AC epoxidation process on commercial titanosilicalites (Table 15) [33] showed that TS-1 sample with a small fraction of the amorphous component (Figure 15), a large silicate modulus and crystallite size, as well as a smaller number of acid sites (Figure 22), is inferior in all parameters to the TS-2 and TS-3 samples with Si/Ti $\sim 47$ and crystal sizes 55.7 and $66.3 \mathrm{~nm}$ (Table 11), respectively, but better than synthesized TS-4, TS-4(348) and TS-4(773) titanosilicalites with $\mathrm{Si} / \mathrm{Ti}=73.5$.

Table 15. Comparison of the main parameters for the process of allyl chloride $(A C)$ epoxidation to epichlorohydrin $(E C H)$ on titanosilicalite catalysts $\left(\mathrm{T}=303 \mathrm{~K}\right.$, atmospheric pressure, $\mathrm{C}_{E C H}=\mathrm{C}_{\mathrm{H}_{2} \mathrm{O}_{2}}=$ $2.35 \mathrm{~mol} / \mathrm{L}$ ) (data from $[33,34])$.

\begin{tabular}{|c|c|c|c|c|c|}
\hline Sample & $\tau, \min$ & $\begin{array}{c}S_{E C H \mid A C} \% \\
\text { (Equation (4), } \\
\text { Section 3.1) }\end{array}$ & $\begin{array}{c}S_{E C H \mid \mathrm{H}_{2} \mathrm{O}_{2}}, \% \\
\text { (Equation (4), } \\
\text { Section 3.1) }\end{array}$ & $\begin{array}{c}\alpha_{A C}, \% \\
\text { (Equation (2), } \\
\text { Section 3.1) }\end{array}$ & $\begin{array}{c}\alpha_{\mathrm{H}_{2} \mathrm{O}_{2}}, \% \\
\text { (Equation (2), } \\
\text { Section 3.1) }\end{array}$ \\
\hline TS-1 & \multirow{6}{*}{85} & 48.5 & 70.6 & 98.0 & 65.5 \\
\hline TS-2 & & 67.9 & 92.5 & 84.8 & 67.4 \\
\hline TS-3 & & 66.2 & 90.9 & 86.1 & 66.2 \\
\hline TS-4 & & 22.5 & 26.0 & 34.5 & 26.3 \\
\hline TS-4(348) & & 18.8 & 49.7 & 24.5 & 8.9 \\
\hline TS-4(773) & & 32.3 & 41.6 & 8.7 & 6.8 \\
\hline TS-2(773) & \multirow{5}{*}{120} & 74.2 & 79.2 & 82.5 & 62.3 \\
\hline TS-3(773) & & 70.9 & 90.4 & 85.8 & 67.6 \\
\hline TS-4 & & 29.2 & 26.5 & 30.6 & 26.5 \\
\hline TS-4(348) & & 19.4 & 34.3 & 33.6 & 10.6 \\
\hline TS-4(773) & & 16.5 & 42.0 & 17.9 & 7.1 \\
\hline
\end{tabular}

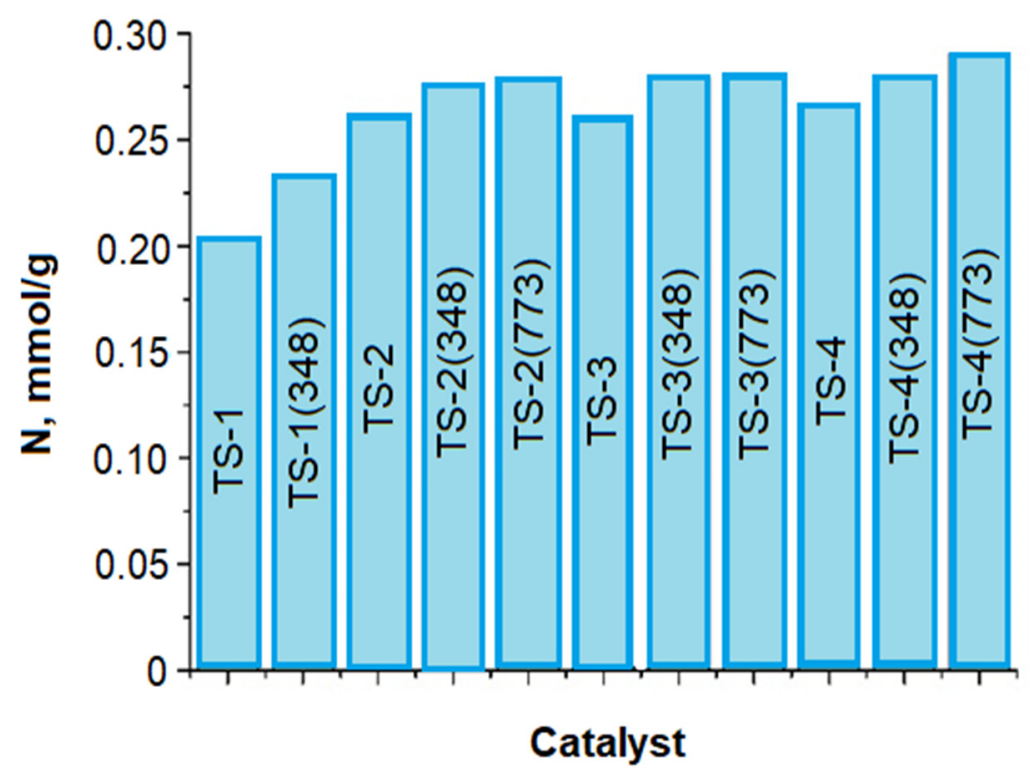

Figure 22. The total acidity of the studied samples (data from [33,34]).

According to Table 13, in the structures of TS-1, TS-2, and TS-3, titanium ions are located in T2, T6, T10 (TS-1), T8, T10 (TS-2) and T2, T10, T12 (TS-3) sites (only T10 site is the same for all three samples) [33]. In TS-4 samples, titanium ions occupy other sites: T1 and T6 [34]. Therefore, it can be concluded that the determining factors affecting the catalytic properties in $P$ conversion are the silicate modulus $(\mathrm{Si} / \mathrm{Ti})$ and the distribution of titanium ions over titanosilicalite crystal structure sites.

Ethanol conversion proceeds in two directions: dehydrogenation with acetaldehyde ( $\mathrm{AcH}$, $\mathrm{CH}_{3} \mathrm{CHO}$ ) formation (reaction 15-the main one) and intramolecular dehydration with ethylene $\left(E T H, \mathrm{C}_{2} \mathrm{H}_{4}\right)$ formation-(reaction 16-by-product), described in Section 3.1.1. 
The resulting $\mathrm{AcH}$ (reaction 18) is one of the important products of organic synthesis, which is obtained in industry from petroleum and natural gas. The best results among the studied catalysts were shown by samples TS-1, TS-2, TS-1(348) with $\alpha_{E(\max )}=57-69 \%$ in the temperature range of $513-648 \mathrm{~K}: \mathrm{T}=573 \mathrm{~K}$ for TS-1, $\mathrm{T}=613 \mathrm{~K}$ for TS-2, $\mathrm{T}=573-613 \mathrm{~K}$ for TS-1(348) and T = $648 \mathrm{~K}$ for TS-2(348) (Figure 23a).

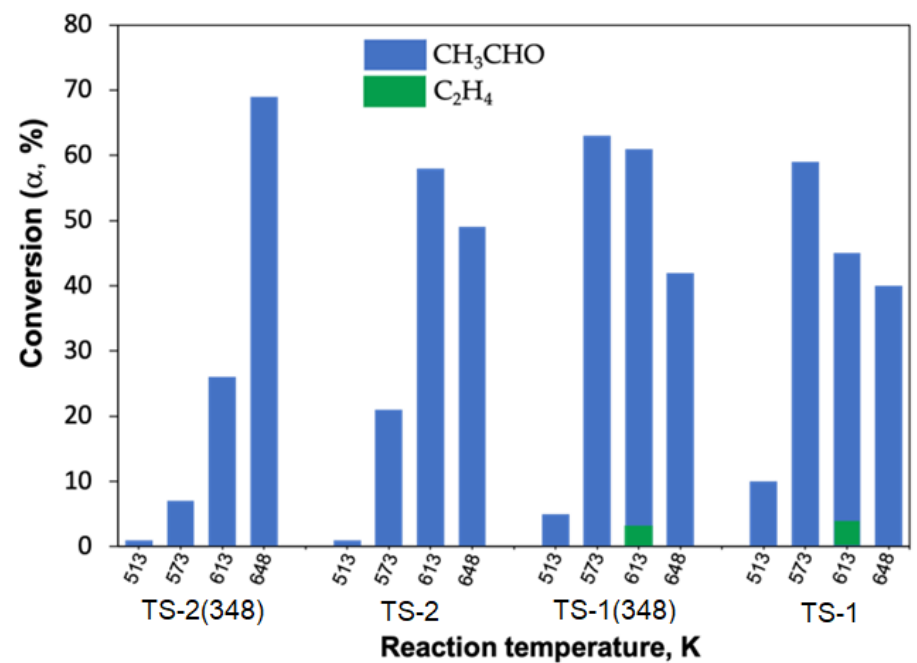

(a)

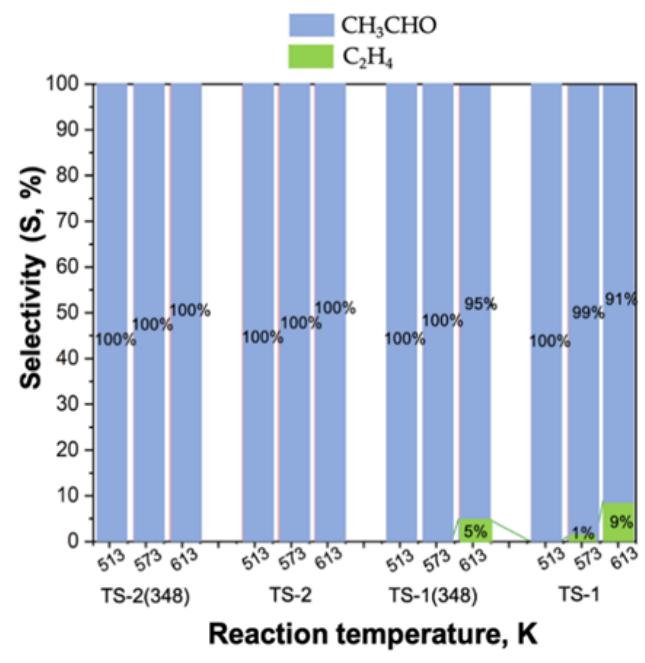

(b)

Figure 23. Conversion $(\alpha, \%)(\mathbf{a})$ and selectivity $(\mathrm{S}, \%)(\mathbf{b})$ of ethanol (data from [33]).

All the samples are characterized by high selectivity for $A c H$ (Figure 23b) $\left(\mathrm{S}_{A c H}=95-100 \%\right)$ in the temperature range of $513-613 \mathrm{~K}$ with $\mathrm{S}_{A c H(\max )}=100 \%$ for TS-2 and TS-2(348) at all temperatures, for TS-1(348) at T $=513-573 \mathrm{~K}$, and for TS- 1 at T $=513 \mathrm{~K}$. The CN Ti $\sim 4.5$ in the local structures of TS-2 and TS-2(348) are the same (Table 14).

The formation of $E T H$ as a by-product (reaction 16) can be associated with the reduction in titanium ions under the action of reactive hydrogen.

The number of acid sites on TS-2 and TS-2(348) samples is $0.26-0.28 \mathrm{mmol} / \mathrm{g}$, which is somewhat higher than that on TS-1(348) and TS-1 (Figure 22). This, apparently, makes it difficult for the dehydrogenation reaction to proceed at low temperatures, but at the same time it is the reason for the absence of the side dehydration reaction (reaction 19) in the studied region up to $673 \mathrm{~K}$.

Catalytic performance obtained with this series of samples is superior to known supported oxide catalysts [172].

Propane conversion (temperature $523-1173 \mathrm{~K}$ ) on tiranosilicalites proceeds according to two main mechanisms (Section 3.1.1.4, reactions 9 and 10).

Analysis of the samples catalytic activity in $P$ conversion showed the highest $P$ decomposition degree $\left(\alpha_{P(\max )} \sim 100 \%\right)$ (Table 16) for TS-4(348) and TS-4(773) catalysts with a larger silicate modulus ( $\mathrm{Si} / \mathrm{Ti} ~ 73.5)$ and a larger number of acid sites (Figure 22). The lowest $\alpha_{P}=33 \%$ under the same conditions is for TS- 1 sample (Table 16).

The same tendency is observed as in E conversion at $648 \mathrm{~K}$ (Figure 23a): TS-2(348) > TS-2 > TS-1S $\approx$ TS-1(348).

Apart from the by-products of alkanes and hydrogen the formation of two more unsaturated hydrocarbons, $P P\left(\mathrm{C}_{3} \mathrm{H}_{6}\right)$ and butadiene $\left(\mathrm{C}_{4} \mathrm{H}_{6}\right)$, was observed (reactions 9 and 10). 
Table 16. Optimal propane cracking reaction performance $(\mathrm{T}=973 \mathrm{~K})($ data from $[33,34])$.

\begin{tabular}{|c|c|c|c|c|c|c|c|c|c|c|c|c|}
\hline & 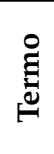 & $\stackrel{\vec{\omega}}{\grave{H}}$ & 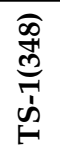 & $\stackrel{N}{\mathscr{N}}$ & 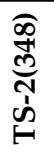 & 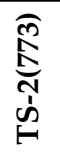 & $\begin{array}{l}m \\
\omega\end{array}$ & 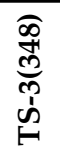 & 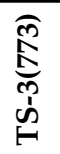 & ڤે' & 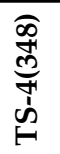 & 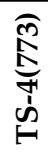 \\
\hline \multicolumn{13}{|c|}{$\alpha_{P}, \%$} \\
\hline & 21 & 32 & 43 & 55 & 73 & 73 & 51 & 71 & 75 & 86 & 98 & 98 \\
\hline \multicolumn{13}{|c|}{$\mathrm{S}, \%$} \\
\hline $\mathrm{C}_{2} \mathrm{H}_{4}(E T H)$ & 0 & 43 & 43 & 58 & 85 & 83 & 56 & 85 & 80 & 42 & 41 & 40 \\
\hline $\mathrm{C}_{3} \mathrm{H}_{6}(P P)$ & 0 & 15 & 15 & 9 & 9 & 13 & 14 & 13 & 14 & 5 & 9 & 9 \\
\hline $\mathrm{C}_{4} \mathrm{H}_{6}$ & 0 & 6 & 11 & 4 & 3 & 5 & 2 & 4 & 5 & 4 & 15 & 15 \\
\hline
\end{tabular}

The TS samples selectivity $(\mathrm{S}, \%)$ determination for the main reaction products $(E T H$, $P P$, butadiene as well as methane and ethane) was carried out up to the optimum cracking temperature of $973 \mathrm{~K}$. It should be noted that at $\mathrm{T}=973 \mathrm{~K}$ the $\mathrm{S}_{E T H} \%$ decreases in the row TS-2(348) $\approx$ TS-3(348) $\approx$ TS-2(773) $\approx$ TS-3(773) $>$ TS- $\approx$ TS-3 $>$ TS-1(348) $\approx$ TS- $1 \approx$ TS- $4 \approx$ TS-1(348) $\approx$ TS-1(773) (Table 16) as in the case of alcohol dehydrogenation with AcH formation at $\mathrm{T}=613 \mathrm{~K}$ (Figure 23b). Moreover, the selectivity for PP and butadiene at $\mathrm{T}=973 \mathrm{~K}$ is almost 10 times less, which indicates a more favorable course of the destruction process. (Table 16). The tendency in the butadiene formation is traced in the row TS-4(773) $\approx$ TS-4(348) > TS-1(348) > TS-1 $\approx$ TS-2(773) $\approx$ TS-3(773) $>$ TS- $2 \approx$ TS-3(348) $\approx$ TS-4 $>$ TS-2(348) $>$ TS-3, but the quantitative formation is small ( 2 to 15\%) (Table 16). This product is specific in the course of the thermocatalytic process and is very valuable. The multiple bonds position cannot be identified, since in the chromatographic analysis of the reaction products, the retention time of butadiene 1-2 $\left(\mathrm{C}_{4} \mathrm{H}_{6}\right)$ and butadiene 1-3 $\left(\mathrm{C}_{4} \mathrm{H}_{6}\right)$ is comparable.

The results obtained are consistent with the total acidity ( $\mathrm{N}$ value), which decreases in the row TS-4(773) $>$ TS-2(773) $\approx$ TS-3(348) $\approx$ TS-3(773) $\approx$ TS-4(348) $>$ TS- $2 \approx$ TS-3 $\approx$ TS- $4>$ TS-1(348) > TS-1 (Figure 22). The smallest N value is in TS-1 with the highest coordination number for titanium in the local structure (Table 14).

\section{Conclusions}

The work presents the synthesis and characterization (surface and bulk compositions; structural and textural characteristics) of (H)ZSM zeolites (MFI type) with $\mathrm{Si} / \mathrm{Al}=12$, $25,40,300$ and $\mathrm{Si} / \mathrm{Ti} \sim 47,53$, and 73.5 as well as composites based on aluminosilicalites with nanoscale anatase NA, both nominally pure (NA/HZSM and NA/HZSM-1,2) and doped with transition metals (NT:M/HZSM-3, $M=\mathrm{Ni}, \mathrm{V}, \mathrm{Ag}$ ). The results obtained indicate the realization of photocatalytic, adsorption, and biocidal properties only for the NA/HZSM and NA:M/HZSM nanocomposites, which is associated with nanosized anatase (NA or NA:M) located on the surface of zeolite particles. By varying the methods or conditions for nanocomposites fabrication, one can change the NA or NA: $M$ characteristics, and hence the properties. The materials prepared can be used for complex purification of water from harmful pollutant (pesticide, and fungicide) under sunlight irradiation, $\mathrm{Se}(\mathrm{VI}), \mathrm{P}(\mathrm{V}), \mathrm{As}(\mathrm{V})$ ions, and pathogenic bacteria both under sunlight and in the dark. Due to the bacteriostatic activity of composites, they are perspective as a component for wound dressings, disinfectant, and antiseptic ointments. The coating of cheap and biocompatible zeolites HZSM with NA or NT:M will significantly reduce the undesirable effect of nanoscale objects on the environment and the cost of the final product.

The transition from aluminosilicalites HZSM to nanocomposites NA/HZSM with $\mathrm{Si} / \mathrm{Al}=12,25,40,300$ and further to titanium silicalites with $\mathrm{Si} / \mathrm{Ti} \sim 47,53,73.5$ leads to a change in catalytic properties (selectivity, conversion, and yield of main products) in propane and ethanol cracking reactions. A considerable improvement in the catalytic process with new reaction products obtained was observed in the case of using titanosilicalites, which makes it possible to recommend them as catalysts for a wide range of applications. 


\section{Patents}

1. Kuzmicheva, G.M.; Podbelsky, V.V.; Stepanov, A.N.; Gainanova, A.A. Program for processing diffraction patterns of nanosized and amorphous substances and calculating the substructure characteristics. Certificate of state registration of software package No. 2017610699 [Russ.].

2. Kuzmicheva, G.M.; Podbelsky, V.V.; Timaeva, O.I.; Iskhakova, L.R. Software for IR spectra processing and correlating absorption bands with reference standards. Certificate of state registration of software package No. 2017611789 [Russ.].

3. Kuzmicheva, G.M.; Podbelsky, V.V.; Mulakov, S.P. Program for processing the data of the chemiluminescence method and calculating the concentration of reactive oxygen species. Certificate of state registration of software package No. 201866661169 [Russ.].

4. Kravchenko, G.V.; Podbelsky, V.V.; Kuzmicheva, G.M. Program for quantitative and qualitative diffraction phase analysis of samples in a system with zeolites. Certificate of state registration of software package No. 2020612665 [Russ.].

5. Kravchenko, G.V.; Podbelsky, V.V.; Kuzmicheva, G.M. Program for determining the dimensions of voids in frame structures Certificate of state registration of software package No. 2020667596 [Russ.].

Supplementary Materials: The following are available online at https:/ / www.mdpi.com/article/ 10.3390/cryst11121451/s1, Section S1: Synthesis of HZSM zeolites, NA/HZSM and NA:M/HZSM nanocomposites; Table S1: Synthesis conditions for the studied zeolites HZSM (Si/Al) and ZSM (Si/Ti) (TS) [16,33,34]; Table S2: Samples characterization methods [16,33,34,54,65,66,68,69]; Section S2: Characterization Methods; Section S2.1: X-ray powder diffraction analysis (XRPD); Section S2.2 FTIR spectroscopy; Section S2.3 Low temperature nitrogen adsorption method; Section S2.4 X-ray Absorption Spectroscopy (XAS-method); Section S2.5 Scanning electron microscopy (SEM) and energy-dispersive X-ray spectroscopy (EDS); Section S2.6 X-ray photoelectron spectroscopy (XPS); Section S2.7 Differential scanning calorimetry (DSC); Section S2.8 UV-Vis diffuse reflectance spectroscopy; Section S2.9 Chemiluminescence Method; Section S2.10 Temperature Programmed Desorption (TPD); Section S2.11 UV-VIS spectroscopy; Section S2.12 Functional Properties; Section S2.12.1. Catalytic properties; Section S2.12.1.1. Propane conversion; Section S2.12.1.2. Ethanol dehydration/dehydrogenation; Section S2.12.1.3. Allyl chloride conversion; Section S2.12.2. Photocatalytic activity (PCA); Section S2.12.2.1. Photodegradation reaction of model dyes (UV irradiation); Section S2.12.2.2. Photodegradation reaction of real pollutants (visible light); Section S2.12.3. Adsorption properties in the dark; Section S2.12.4. Antimicrobial activity in the dark (AMA); Table S3: Some characteristics of HZSM and NA/HZSM (data from [16,66]); Figure S1: Diffraction patterns of HZSM (red), NA/HZSM (Method 1a) (blue): Si / Al = 12 (a), 40 (b), 300 (c) $(\lambda-1.54051 \AA$ ) and the relationship between $\operatorname{HZSM}(\bullet)$ and NA/HZSM $(\triangle)$ unit cell volume and water molecules content in the framework cavities (XRPD) (d). Red arrow marks silicon-containing oxygenous formations, black arrow—nanoscale anatase; Figure S2: DSC thermograms of HZSM zeolites (a) and NA/HZSM nanocomposites obtained by Method 1b-NA/HZSM-1 (b) and Method 2-NA/HZSM2 (c): $\mathrm{I}-\mathrm{Si} / \mathrm{Al}=12, \mathrm{II}-\mathrm{Si} / \mathrm{Al}=25, \mathrm{III}-\mathrm{Si} / \mathrm{Al}=40$; Figure S3: UV-Vis spectra of pyridine adsorption on HZSM, NA/HZSM-1 and NA/HZSM-2; Figure S4: SEM images of HZSM(12) (a), HZSM(25) (b), $\operatorname{HZSM}(40)$ (c), $\operatorname{HZSM}(300)(d)$; Figure S5: SEM images of NA/HZSM(12) (a), NA/HZSM(40) (b), NA/HZSM(300) (c); Figure S6: SEM images of NA/HZSM(12)-1 (a), NA/HZSM(40)-1 (b), NA/HZSM(300)-1(c), NA/HZSM(12)-2 (d), NA/HZSM(40)-2 (e), NA/HZSM(300)-2(f); Figure S7: DSC thermograms of TS-1 (a), TS-1(348) (b), TS-2 (c), TS-2(348) (d), TS-3 (e), TS-3(348) (f), TS-4 (g), TS-4(348) (h), and TS-4(348) (i) recorded into two stages: first scanning is a black line, and second scanning (after sample cooling to the initial experimental temperature) is a red line.

Author Contributions: Conceptualization, G.M.K.; methodology, G.M.K.; validation, G.M.K. and E.N.D.; formal analysis, G.M.K., E.N.D. and G.V.K.; investigation, G.M.K. and E.N.D.; resources, G.M.K.; data curation, G.M.K. and E.N.D.; writing-original draft preparation, E.N.D.; writingreview and editing, G.M.K.; visualization, E.N.D. and G.V.K.; supervision, G.M.K.; project administration, E.N.D.; funding acquisition, G.M.K. All authors have read and agreed to the published version of the manuscript. 
Funding: This research was funded by Ministry of Science and Higher Education of the Russian Federation, grant number 0706-2020-0026.

Institutional Review Board Statement: Not applicable.

Informed Consent Statement: Not applicable.

Conflicts of Interest: The authors declare no conflict of interest. The funders had no role in the design of the study; in the collection, analyses, or interpretation of data; in the writing of the manuscript, or in the decision to publish the results.

\section{References}

1. Baerlocher, C.; McCusker, L.B.; Olson, D.H. Atlas of Zeolite Framework Types, 6th ed.; Elsevier: Amsterdam, The Netherlands, 2007; p. 405.

2. McCusker, L.B.; Liebau, F.; Engelhardt, G. Nomenclature of structural and compositional characteristics of ordered microporous and mesoporous materials with inorganic hosts (IUPAC Recommendations 2001). Pure Appl. Chem. 2001, 73, 381-394. [CrossRef]

3. International Zeolite Association. Available online: http://www.iza-online.org (accessed on 29 February 2020).

4. Guo, P.; Wan, W.; McCusker, L.; Baerlocher, C.; Zou, X. On the relationship between unit cells and channel systems in high silica zeolites with the "butterfly" projection. Z. Kristallogr. 2015, 230, 301-309. [CrossRef]

5. Losch, P.; Pinar, A.B.; Willinger, M.G.; Soukup, K.; Chavan, S.; Vincent, B.; Pale, P.; Louis, B. H-ZSM-5 zeolite model crystals: Structure-diffusion-activity relationship in methanol-to-olefins catalysis. J. Catal. 2017, 345, 11-23. [CrossRef]

6. Bhat, S.U.; Naikoo, R.A.; Bhat, R.A.; Malla, M.A.; Tomar, R.; Gatum, N.K.; Tiwari, K.R. H-mordenite zeolite as an efficient, rapid and recyclable catalyst for chemoselective synthesis of 1,1-diacetates under solvent-free conditions. Asian J. Green Chem. 2017, 1, 46-55. [CrossRef]

7. Tai, S.B.Y. Lignin Fast Pyrolysis: Towards Enhanced Product Selectivities by Varying Particle Sizes of HZSM-5 Zeolites; Swiss Federal Institute of Technology Zurich: Zurich, Switzerland, 2016; p. 66.

8. $\quad$ Lowell, S.; Shields, J.E.; Thomas, M.A.; Thommes, M. Micropore Analysis BT_Characterization of Porous Solids and Powders: Surface Area, Pore Size and Density; Springer: Berlin/Heidelberg, Germany, 2004; pp. 129-156.

9. Hartmann, M. Hierarchical Zeolites: A Proven strategy to combine shape selectivity with efficient mass transport. Chem. Int. Ed. 2004, 43, 5880-5882. [CrossRef]

10. Donk, S.; Broersma, A.; Gijzeman, O.L.J.; Bokhoven, J.A.; Bitter, J.H.; Jong, K.P. Combined diffusion, adsorption, and reaction studies of n-hexane hydroisomerization over $\mathrm{Pt} / \mathrm{H}-$ mordenite in an oscillating microbalance. J. Catal. 2001, 204, 272-280. [CrossRef]

11. Perez-Ramirez, J.; Kapteijn, F.; Groen, J.C.; Domenech, A.; Mul, G.; Moulijn, J.A. Steam-activated Fe-MFI zeolites. Evolution of iron species and activity in direct N2O decomposition. J. Catal. 2003, 214, 33-45. [CrossRef]

12. Database of Zeolite Structures. Available online: http:/ / europe.iza-structure.org/ (accessed on 29 November 2020).

13. Dyer, A. An Introduction to Zeolite Molecular Sieves; Wiley: Hoboken, NJ, USA, 1988; p. 149.

14. Smail, H.A.; Rehan, M.; Shareef, K.M.; Ramli, Z.; Nizami, A.; Gardy, J. Synthesis of Uniform Mesoporous Zeolite ZSM-5 Catalyst for Friedel-Crafts Acylation. ChemEngineering 2019, 3, 35. [CrossRef]

15. Widayat, W.; Roesyadi, A.; Rachimoellah, M. Diethyl Ether Production Process with Various Catalyst Type. Internat. J. Sci. Eng. 2013, 4, 6-10. [CrossRef]

16. Domoroshchina, E.; Kravchenko, G.; Kuz'micheva, G.; Markova, E.; Zhukova, A.; Pirutko, L.; Khramov, E.; Dorokhov, A.; Koroleva, A. The Role of the Compositions of HZSM-5 Zeolites modified with Nanosized Anatase in Propane and Ethanol Conversion. Catal. Today 2021. (In press) [CrossRef]

17. Fan, D.; Dai, D.; Wu, H. Ethylene Formation by Catalytic Dehydration of Ethanol with Industrial Considerations. Materials 2013, 6, 101-115. [CrossRef]

18. Hunger, B.; Matysik, S.; Heuchel, M.; Einicke, W. Adsorption of Methanol on ZSM-5 Zeolites. Langmuir 1997, 13, 6249-6254. [CrossRef]

19. Ivanov, A.V.; Grahama, G.W.; Shelefa, M. Adsorption of hydrocarbons by ZSM-5 zeolites with different $\mathrm{SiO}_{2} / \mathrm{Al}_{2} \mathrm{O}_{3}$ ratios: $\mathrm{A}$ combined FTIR and gravimetric study. Appl. Catal. B Environ. 1999, 21, 243-258. [CrossRef]

20. Szanyi, J.; Paffett, M.T. The adsorption of carbon monoxide on H-ZSM-5 and hydrothermally treated H-ZSM-5. Microporous Mater. 1996, 7, 201-218. [CrossRef]

21. Lamia, M.; Fatiha, D.; Mohammed, B.; Ayada, D. Adsorption of Methyl Green onto Zeolite ZSM-5(pyrr.) in aqueous solution. Orient. J. Chem. 2016, 31, 171-180. [CrossRef]

22. Bagane, M.; Guiza, S. Removal of a dye from textile effluents by adsorption. Ann. Chim. Sci. Mater. 2000, 25, 615-626. [CrossRef]

23. Zhang, T.; Chen, X.; Chen, G.; Chen, M.; Bai, R.; Jia, M.; Yu, J. Synthesis of anatase-free nano-sized hierarchical TS-1 zeolites and their excellent catalytic performance in alkene epoxidation. J. Mater. Chem. A 2018, 6, 9473-9479. [CrossRef]

24. Adedigba, A.; Sankar, G.; Catlow, C.R.A.; Du, Y.; Xi, S.; Borgna, A. On the synthesis and performance of hierarchical nanoporous TS-1 catalysts. Microporous Mesoporous Mater. 2017, 244, 83-92. [CrossRef] 
25. Bai, R.; Zou, Y.; Sun, Q.; Song, Y.; Wang, N.; Zhang, T.; Wang, F.; Feng, Z.; Miao, S.; Yu, J. Intermediate-crystallization promoted catalytic activity of titanosilicate zeolites. J. Mater. Chem. A 2018, 6, 8757-8762. [CrossRef]

26. Du, Q.; Guo, Y.; Wu, P.; Liu, H. Synthesis of hierarchically porous TS-1 zeolite with excellent deep desulfurization performance under mild conditions. Microporous Mesoporous Mater. 2018, 264, 272-280. [CrossRef]

27. Gao, X.; An, J.; Gu, J.; Li, L.; Li, Y. A green template-assisted synthesis of hierarchical TS-1 with excellent catalytic activity and recyclability for the oxidation of 2,3,6-trimethylphenol. Microporous Mesoporous Mater. 2017, 239, 381-389. [CrossRef]

28. Hammond, C.; Padovan, D.; Tarantino, G. Porous metallosilicates for heterogeneous, liquid-phase catalysis: Perspectives and pertaining challenges. R. Soc. Open Sci. 2018, 5, 171315. [CrossRef] [PubMed]

29. Jiao, Y.; Adedigba, A.-L.; He, Q.; Miedziak, P.; Brett, G.; Dummer, N.F.; Perdjion, M.; Liu, J.; Hutchings, G.J. Inter-connected and open pore hierarchical TS-1 with controlled framework titanium for catalytic cyclohexene epoxidation. Catal. Sci. Technol. 2018, 8, 2211-2217. [CrossRef]

30. Lu, X.; Xu, H.; Yan, J.; Zhou, W.-J.; Liebens, A.; Wu, P. One-pot synthesis of ethylene glycol by oxidative hydration of ethylene with hydrogen peroxide over titanosilicate catalysts. J. Catal. 2018, 358, 89-99. [CrossRef]

31. Xiong, G.; Hu, D.; Guo, Z.; Meng, Q.; Liu, L. An efficient Titanium silicalite-1 catalyst for propylene epoxidation synthesized by a combination of aerosol-assisted hydrothermal synthesis and recrystallization. Microporous Mesoporous Mater. 2018, 268, 93-99. [CrossRef]

32. Song, Z.; Feng, X.; Sheng, N.; Lin, D.; Li, Y.; Liu, Y.; Yang, C. Propene epoxidation with $\mathrm{H}_{2}$ and $\mathrm{O}_{2}$ on Au/TS-1 catalyst: Cost-effective synthesis of small-sized mesoporous TS-1 and its unique performance. Catal. Today 2020, 347, 102-109. [CrossRef]

33. Kuz'micheva, G.M.; Svetogorov, R.D.; Khramov, E.V.; Kravchenko, G.V.; Bruk, L.G.; Pastukhova, Z.Y.; Markova, E.B.; Zukova, A.I.; Chuklina, S.G.; Dorokhov, A.V. Titanosilicalites (MFI-type): Composition, statistical and local structure, catalytic properties. Microporous Mesoporous Mater. 2021, 326, 111377. [CrossRef]

34. Domoroshchina, E.; Kravchenko, G.; Kuz'micheva, G.; Markova, E.; Jukova, A.; Pirutko, L.; Khramov, E.; Dorokhov, A.; Koroleva, A. The Role of the Compositions of HZSM-5 Zeolites modified with Nanosized Anatase in Propane and Ethanol Conversion and Allyl Chloride and Allyl Alcohol Epoxidation. In Proceedings of the 5th International Conference on Catalysis and Chemical Engineering, San Francisco, CA, USA, 22-26 February 2021.

35. Nemeth, L.; Bare, S. Chapter one-Science and technology of framework metal-containing zeotype catalysts. In Book Advances in Catalysis; Jentoft, F., Ed.; Elsevier: Amsterdam, The Netherlands, 2014; Volume 57, pp. 1-97.

36. Serrano, D.P.; Calleja, G.; Botas, J.A.; Gutierrez, F.J. Characterization of adsorptive and hydrophobic properties of silicalite-1, ZSM-5, TS-1 and Beta zeolites by TPD techniques. Sep. Purif. Technol. 2007, 54, 1-9. [CrossRef]

37. Thanh, D.N.; Kikhtyanin, O.; Ramos, R.; Kothari, M.; Ulbrich, P.; Munshi, T.; Kubička, D. Nanosized TiO 2 -A promising catalyst for the aldol condensation of furfural with acetone in biomass upgrading. Catal. Today 2016, 277, 97-107. [CrossRef]

38. Liu, S.; Tang, N.; Shang, Q.; Wu, C.; Xu, G.; Cong, Y. Superior performance of iridium supported on rutile titania for the catalytic decomposition of $\mathrm{N}_{2} \mathrm{O}$ propellants. Chin. J. Catal. 2018, 39, 1189-1193. [CrossRef]

39. Liu, S.; Cong, Y.; Huang, Y.; Zhao, X.; Zhang, T. $\mathrm{TiO}_{2}$ promoted $\mathrm{Ir} / \mathrm{Al}_{2} \mathrm{O}_{3}$ catalysts for direct decomposition of $\mathrm{N}_{2} \mathrm{O}$. Catal. Today 2011, 175, 264-270. [CrossRef]

40. Timaeva, O.; Nikolaichik, V.; Svetogorov, R.; Kuz'micheva, G. Impact of the production method and diagnostics conditions on the compositions and structure of nanodimensional anatase. Cryst. Mater. 2020, 235, 127-136. [CrossRef]

41. Timaeva, O.I.; Chihacheva, I.P.; Kuzmicheva, G.M.; Saf'yanova, L.V.; Chumakov, R.G.; Terekhova, R.P. Preparation, physicochemical properties and antimicrobial activity of $\eta$-modification of titanium(IV) oxide intercalated with poly(N-vinylcaprolactam). Appl. Nanosci. 2018, 8, 1729-1741. [CrossRef]

42. Serkhacheva, N.S.; Yashina, N.V.; Prokopov, N.I.; Gaynanova, A.A.; Kuz'micheva, G.M.; Domoroshchina, E.N.; Sadovskaya, N.V.; Prokudina, N.A.; Gervald, A.Y. Bactericidal Properties of Nanoscale Zinc(II) and Titanium (IV) Oxides of Different Nature and Their Nanocomposites with Polystyrene. Nanotechnol. Russ. 2016, 11, 99-109. [CrossRef]

43. Gainanova, A.A.; Kuz'micheva, G.M.; Vasil 'eva, I.G. Nanosized low-temperature phases of titanium(IV) oxide with anatase and $\eta$-phase structures: Composition, structure, and photocatalytic properties. Russ. Chem. Bull. Int. Ed. 2018, 67, 1350-1363. [CrossRef]

44. Banerjee, S.; Pillai, S.; Falaras, P.; O'Shea, K.; Byrne, J.; Dionysiou, D. New insights into the mechanism of visible light photocatalysis. J. Phys. Chem. Lett. 2014, 5, 2543-2554. [CrossRef] [PubMed]

45. Gainanova, A.; Kuz'micheva, G.; Khramov, E.; Chumakov, R.; Zybinskiy, A.; Yashina, N. The role of composition and structure of vanadium-doped nanosized titanium(iv) oxides (anatase and $\eta$-phase) in the realization of photocatalytic, adsorption and bactericidal properties. New J. Chem. 2018, 42, 13025-13037. [CrossRef]

46. Lin, W.C.; Lin, Y.J. Effect of Vanadium(IV)-Doping on the Visible Light-Induced Catalytic Activity of Titanium Dioxide Catalysts for Methylene Blue Degradation. Environ. Eng. Sci. 2012, 29, 447-452. [CrossRef]

47. Bensouici, F.; Bououdina, M.; Dakhel, A.A.; Tala-Ighil, R.; Tounane, M.; Iratni, A.; Cai, W. Optical, structural and photocatalysis properties of $\mathrm{Cu}$-doped $\mathrm{TiO}_{2}$ thin films. Appl. Surf. Sci. 2017, 395, 110-116. [CrossRef]

48. Ma, X.; Xue, L.; Yin, S.; Yang, M.; Yan, Y. Preparation of V-doped $\mathrm{TiO}_{2}$ photocatalysts by the solution combustion method and their visible light photocatalysis activities. J. Wuhan Univ. Technol.-Mater. Sci. Ed. 2014, 29, 863-868. [CrossRef] 
49. Kamegawa, T.; Sugimura, K.; Maki, K.; Mori, K.; Yamashita, H. Hydrothermal synthesis of visible light sensitive vanadium doped $\mathrm{TiO}_{2}$ photocatalysts and their applications for the degradation of isobutanol diluted in water. J. Phys. Conf. Ser. 2009, $165,012038$. [CrossRef]

50. Bhatia, V.; Dhir, A. Transition metal doped $\mathrm{TiO}_{2}$ mediated photocatalytic degradation of anti-inflammatory drug under solar irradiations. J. Environ. Chem. Eng. 2016, 4, 1267-1273. [CrossRef]

51. Turkten, N.; Cinar, Z.; Tomruk, A.; Bekbolet, M. Copper-doped $\mathrm{TiO}_{2}$ photocatalysts: Application to drinking water by humic matter degradation. Environ. Sci. Pollut. Res. 2019, 26, 36096-36106. [CrossRef]

52. Murashkina, A.A.; Murzin, P.D.; Rudakova, A.V.; Ryabchuk, V.K.; Emeline, A.V.; Bahnemann, D.W. Influence of the Dopant Concentration on the Photocatalytic Activity: Al-Doped $\mathrm{TiO}_{2}$. J. Phys. Chem. C 2015, 119, 24695-24703. [CrossRef]

53. Mathew, S.; Ganguly, P.; Rhatigan, S.; Kumaravel, V.; Byrne, C.; Hinder, S.; Barlett, J.; Nolan, M.; Pillai, S. Cu-Doped TiO 2 : Visible Light Assisted Photocatalytic Antimicrobial Activity. Appl. Sci. 2018, 8, 2067. [CrossRef]

54. Domoroshchina, E.; Kravchenko, G.; Kuz'micheva, G. Nanocomposites of zeolite-titanium(IV) oxides: Preparation, characterization, adsorption, photocatalytic and bactericidal properties. J. Cryst. Growth 2017, 468, 199-203. [CrossRef]

55. Zhang, W.J.; Li, K.X.; Yu, Y. Photocatalytic Activity of $\mathrm{TiO}_{2}$ Loaded on HZSM-5 Zeolite Modified by Ammonia Phosphate. Adv. Mater. Res. 2011, 214, 6-10. [CrossRef]

56. Zhang, W.; Yang, J.; Pei, X. Enhanced photocatalytic activity of $\mathrm{In}_{-} \mathrm{TiO}_{2}$ supported on $\mathrm{HZSM}-5$ zeolite. Optoelectron. Adv. Mater. 2018, 12, 227-230.

57. Zhang, W.; Bi, F.; Yu, Y.; He, H. Phosphoric acid treating of ZSM-5 zeolite for the enhanced photocatalytic activity of TiO $2 / \mathrm{HZSM}^{2} 5$. J. Mol. Catal. A 2013, 372, 6-12. [CrossRef]

58. Su, H.; Ma, Z.; Hu, T.; Zhang, W.; He, H. Sol-gel Synthesis of $\chi \mathrm{TiO}_{2} / \mathrm{HZSM}-5$ Composite Photocatalyst on Degradation of Reactive Brilliant Red X3B. Curr. Nanosci. 2017, 13, 292-298. [CrossRef]

59. Suwarnkar, M.B.; Kadam, A.N.; Khade, G.V.; Gavade, N.L.; Garadkar, K.M. Modification of TiO 2 nanoparticles by HZSM-5 for the enhancement in photodegradation of Acid Green 25. J. Mater. Sci. Mater. Electron. 2015, 27, 843-851. [CrossRef]

60. Lv, Z.; Tao, Y.; Zhang, W. Titanium dioxide supported on HZSM-5 for acid red 1 photocatalytic degradation. React. Kinet. Mech. Catal. 2021, 133, 531-539. [CrossRef]

61. Durgakumari, V.; Subrahmanyam, M.; Subba Rao, K.; Ratnamala, A.; Noorjahan, M.; Tanaka, K. An easy and efficient use of TiO2 supported HZSM-5 and $\mathrm{TiO}_{2}+\mathrm{HZSM}-5$ zeolite combinate in the photodegradation of aqueous phenol and p-chlorophenol. Appl. Catal. A Gen. 2002, 234, 155-165. [CrossRef]

62. Jan, Y.H.; Lin, L.Y.; Karthik, M.; Bai, H. Titanium Dioxide/Zeolite Catalytic Adsorbent for the Removal of NO and Acetone Vapors. J. Air Waste Manag. Assoc. 2012, 59, 1186-1193. [CrossRef]

63. Guo, G.; Hu, Y.; Jiang, S.; Wei, C. Photocatalytic oxidation of $\mathrm{NOx}$ over $\mathrm{TiO}_{2} / \mathrm{HZSM}-5$ catalysts in the presence of water vapor: Effect of hydrophobicity of zeolites. J. Hazard. Mater. 2012, 223-224, 39-45. [CrossRef] [PubMed]

64. Zhang, W.; Wang, K.; Yu, Y. Sol-gel Preparation of Fe-doped $\mathrm{TiO}_{2}$ Loaded on HZSM-5 Zeolite. Adv. Mater. Res. 2011, 146-147, 466-469.

65. Gainanova, A.A.; Domoroshchina, E.N.; Kuz'micheva, G.M.; Khramov, E.V.; Chumakov, R.G.; Gotovtsev, P.M.; Zybinskiy, A.M.; Yashina, N.V.; Pirutko, L.V. New composites based on zeolites (H-Beta, H-ZSM-5) and nanosized titanium(IV) oxide doped by Ni, $\mathrm{Ag}$, V with photocatalytic, adsorption and bactericidal properties. New J. Chem. 2021, 45, 2417-2430. [CrossRef]

66. Kravchenko, G.; Domoroshchina, E.; Kuz'micheva, G.; Gainanova, A.; Amarantov, S.; Pirutko, L.; Tsybinsky, A.; Sadovskaya, N.; Kopylova, E. Zeolite-Titanium Dioxide Nanocomposites: Preparation, Characterization, and Adsorption Properties. Nanotechnol. Russ. 2016, 11, 579-592. [CrossRef]

67. Kravchenko, G.V.; Kormilitsina, S.S.; Domoroshchina, E.N.; Kuz'micheva, G.M.; Chumakov, R.G. Comparison of the results of studying zeolite ZSM-5 with different modules by X-ray photoelectron spectroscopy and atomic emission photoelectron spectroscopy and atomic emission spectrometry with inductively coupled plasma. In Proceedings of the Symposium of the Kurchatov Complex for Synchrotron-Neutron Research Users, Moscow, Russia, 20-23 November 2017; p. 112. (In Russian).

68. Kravchenko, G.V.; Pastukhova, Z.Y.; Levitin, V.V.; Khramov, E.V.; Domoroshchina, E.N.; Kuz'micheva, G.M. Local and Statistical structure of titanium containing zeolites ZSM-5 (MFI) and their relationship with (photo)catalytic properties. In Proceedings of the Scientific and Technical Conference with International Participation "Computer Science and Technology. Innovative Technologies in Industry and Computer Science", Moscow, Russia, 11-12 April 2019; pp. 537-544.

69. Domoroshchina, E.N.; Kravchenko, G.V.; Kuz'micheva, G.M.; Chumakov, R.G. Relationship between the Surface Composition of Titanium Oxide(IV)/Zeolite Nanocomposites and Their Photocatalytic and Adsorption Properties: X-ray Photoelectron Spectroscopy Data. J. Surf. Investig. 2019, 13, 117-123. [CrossRef]

70. Treacy, J.J.; Higgins, J.B. Collection of Simulated XRD Powder Patterns for Zeolites; Elsevier: Amsterdam, The Netherlands, 2001; p. 586.

71. Kuz'micheva, G.M.; Podbel'skii, V.V.; Stepanov, A.N.; Gainanova, A.A. Program for Processing Diffraction Patterns of Nanosized and Amorphous Substances and Calculating the Substructure Characteristics; PC Software Certificate No. 2017610699; E-Max Computer Education Institute: Kurukshetra, India, 2017.

72. Zlokazov, V.B.; Chernyshev, V.V. MRIA-A program for a full profile analysis of powder multiphase neutron-diffraction time-offlight (direct and Fourier) spectra. J. Appl. Crystallogr. 1992, 25, 447-451. [CrossRef] 
73. Petricek, V.; Dusek, M.; Palatinus, L. Crystallographic Computing System JANA2006: General features. Z. Kristallogr. 2014, 229, 345-352. [CrossRef]

74. Toraya, H. Whole-powder-pattern fitting without reference to a structural model: Application to X-ray powder diffraction data. J. Appl. Crystallogr. 1986, 19, 440-447. [CrossRef]

75. Popa, N.C. The (hkl) dependence of diffraction-line broadening caused by strain and size for all laue groups in Rietveld refinement. J. Appl. Crystallogr. 1998, 31, 176-180. [CrossRef]

76. Farhadi, N.; Tabatabaie, T.; Ramavandi, B.; Amiri, F. Optimization and characterization of zeolite-titanate for ibuprofen elimination by sonication/hydrogen peroxide/ultraviolet activity. Ultrason. Sonochem. 2020, 67, 105122. [CrossRef] [PubMed]

77. Van Koningsveld, H.; van Bekkum, H.; Jansen, J.C. The monoclinic framework structure of zeolite H-ZSM-5. Comparison with the orthorhombic framework of as-synthesized ZSM-5. Zeolites 1990, 10, 235-242.

78. Olson, D.H.; Kokotailo, G.T.; Lawton, S.L.; Meier, W.M. Crystal structure and structure-related properties of ZSM-5. J. Phys. Chem. 1981, 85, 2238-2243. [CrossRef]

79. Fyfe, C.A.; Kennedy, G.J.; de Schutter, C.T.; Kokotailo, G.T. Sorbate-induced structural changes in ZSM-5 (silicalite). J. Chem. Soc. Chem. Commun. 1984, 8, 541-542. [CrossRef]

80. Hay, D.G.; Jager, H. Orthorhombic-monoclinic phase changes in ZSM-5 zeolite/silicalite. J. Chem. Soc. Chem. Commun. 1984, 21, 1433. [CrossRef]

81. Hay, D.G.; Jager, H.; West, G.W. Examination of the monoclinic/orthorhombic transition in silicalite using XRD and silicon NMR. J. Phys. Chem. 1985, 89, 1070-1072. [CrossRef]

82. Wu, E.L.; Lawton, S.L.; Olson, G.T.; Rohrman, A.C.; Kokotailo, G.T. ZSM-5-type materials. Factors affecting crystal symmetry. J. Phys. Chem. 1979, 83, 2777-2781. [CrossRef]

83. Nakamoto, H.; Takahashi, H. Crystal symmetry change of ZSM-5 by various treatments. Chem. Lett. 1981, 10, 1013-1016. [CrossRef]

84. Janos, R.A.; Nagy, B.; Aiello, R.; Giordano, G.; Katovic, A.; Testa, F.; Kónya, Z.; Kiricsi, I. Isomorphous Substitution in Zeolites. Mol. Sieves 2007, 5, 365-478.

85. Zecchina, A.; Bordiga, S.; Spoto, G.; Marchese, L.; Petrini, G.; Leofanti, G.; Padovan, M. Silicalite characterization. 1. Structure, adsorptive capacity, and IR spectroscopy of the framework and hydroxyl modes. J. Phys. Chem. 1992, 96, 4985-4990. [CrossRef]

86. Zecchina, A.; Bordiga, S.; Spoto, G.; Marchese, L.; Petrini, G.; Leofanti, G.; Padovan, M. Silicalite characterization. 2. IR spectroscopy of the interaction of carbon monoxide with internal and external hydroxyl groups. J. Phys. Chem. 1992, 96, 4991-4997. [CrossRef]

87. Marra, G.L.; Tozzola, G.; Leofanti, G.; Padovan, M.; Petrini, G.; Genoni, F.; Venturelli, B.; Zecchina, A.; Bordiga, S.; Ricchiardi, G. Part, A., Hölderich, W., Karge, H.G., Weitkamp, J., Pfeifer, H., Eds.; Zeolites and Related Microporous Material: State of the Art; Part A; Elsevier: Amsterdam, The Netherlands, 1994; Volume 84, p. 559.

88. Bleken, B.-T.L.; Wragg, D.S.; Arstad, B.; Gunnæs, A.E.; Mouzon, J.; Helveg, S.; Lillerud, K.P. Unit cell thick nanosheets of zeolite H-ZSM-5: Structure and activity. Top. Catal. 2013, 56, 558-566. [CrossRef]

89. Artioli, G.; Lamberti, C.; Marra, G.L. Neutron powder diffraction study of orthorhombic and monoclinic defective silicalite. Acta Crystallogr. B 2000, 56, 2-10. [CrossRef]

90. Kroger, F.A. The Chemistry of Imperfect Crystals; Mir: Moscow, Russia, 1969; p. 654.

91. Milanesio, M.; Viterbo, D.; Palin, L.; Marra, G.L.; Lamberti, C.; Aiello, R.; Testa, F. Structure analysis of Boron-silicalite and of a "defect-free" MFI-silicalite by synchrotron radiation single crystal X-ray diffraction. Stud. Surf. Sci. Catal. 2002, 142, $1891-1898$.

92. Bordiga, S.; Roggero, I.; Ugliengo, P.; Zecchina, A.; Bolis, V.; Artioli, G.; Lamberti, C. Characterisation of defective silicalites. J. Chem. Soc. Dalton Trans. 2000, 21, 3921-3929. [CrossRef]

93. Inui, M.; Ikeda, T.; Suzuki, T.; Sugita, K.; Mizukami, F. Quantitative Analysis of Structural Defect in Silicalite by Rietveld Refinements Using X-ray Powder Diffraction and 29Si MAS NMR. Bull. Chem. Soc. Jpn. 2009, 82, 1160-1169. [CrossRef]

94. Lamberti, C.; Bordiga, S.; Zecchina, A.; Artioli, G.; Marra, G.; Spanò, G. Ti Location in the MFI Framework of Ti-Silicalite-1: A Neutron Powder Diffraction Study. J. Am. Chem. Soc. 2001, 123, 2204-2212. [CrossRef]

95. Shannon, R.D. Revised effective ionic radii and systematic studies of interatomic distances in halides and chalcogenides. Acta Crystallogr. Sect. A 1976, 32, 751-767. [CrossRef]

96. Urusov, V.S.; Eremim, N.N. Crystal Chemistry. Short Course. Part 2; Moscow University: Moscow, Russia, 2005. (In Russian)

97. Bokii, G.B. Crystal Chemistry; Nauka: Moscow, Russia, 1971; p. 400. (In Russian)

98. Kuz'micheva, G.M. Some Aspects of Applied Crystal Chemistry; MIREA: Moscow, Russia, 2016; p. 286. (In Russian)

99. Round, C.I.; Williams, C.D.; Latham, K.; Duke, C.V.A. Ni-ZSM-5 and Cu-ZSM-5 Synthesized Directly from Aqueous Fluoride Gels. Chem. Mater. 2001, 13, 468-472. [CrossRef]

100. Yuan, E.; Han, W.; Zhang, G.; Zhao, K.; Mo, Z.; Lu, G.; Tang, Z. Structural and Textural Characteristics of Zn-Containing ZSM-5 Zeolites and Application for the Selective Catalytic Reduction of $\mathrm{NOx}_{\text {with }} \mathrm{NH}_{3}$ at High Temperatures. Catal. Surv. Asia 2016, 20, 41-52. [CrossRef]

101. Ali, I.; Hassan, A.; Shabaan, S.; El-Nasser, K. Synthesis and characterization of composite catalysts Cr/ZSM-5 and their effects toward photocatalytic degradation of p-nitrophenol. Arab. J. Chem. 2017, 10, S2106-S2114. [CrossRef]

102. Morgan, C.I.; Paredes, S.P.; Flores, S.O.; Alfaro, S. Single gel hydrothermal synthesis and characterization of vanadium isomorphously modified silicalite-1 and ZSM-5. Mater. Lett. 2017, 209, 513-516. [CrossRef] 
103. Ko, Y.S.; Ahn, W.S. Synthesis and characterization of zirconium silicalite-1. Korean J. Chem. Eng. 1998, 15, 423-428. [CrossRef]

104. Xia, C.; Liu, Y.; Lin, M.; Peng, X.; Zhu, B.; Shu, X. Confirmation of the isomorphous substitution by Sn atoms in the framework positions of MFI-typed zeolite. Catal. Today 2018, 316, 193-198. [CrossRef]

105. Meng, Y.; Genuino, H.C.; Kuo, C.-H.; Huang, H.; Chen, S.-Y.; Zhang, L.; Suib, S.L. One-Step Hydrothermal Synthesis of Manganese-Containing MFI-Type Zeolite, Mn-ZSM-5, Characterization, and Catalytic Oxidation of Hydrocarbons. J. Am. Chem. Soc. 2013, 135, 8594-8605. [CrossRef] [PubMed]

106. Saeidi, M.; Hamidzadeh, M. Co-doping a metal (Cr, Mn, Fe, Co, Ni, Cu, and Zn) on Mn/ZSM-5 catalyst and its effect on the catalytic reduction of nitrogen oxides with ammonia. Res. Chem. Intermed. 2016, 43, 2143-2157. [CrossRef]

107. Szostak, R. Preparation of ferrisilicate ZSM-5 molecular sieves. J. Catal. 1986, 100, 555-557. [CrossRef]

108. Kosslick, H.; Tuan, V.A.; Parlitz, B.; Fricke, R.; Peuker, C.; Storek, W. Disruption of the MFI framework by the incorporation of gallium. J. Chem. Soc. Faraday Trans. 1993, 89, 1131-1138. [CrossRef]

109. Kosslick, H.; Tuan, V.A.; Fricke, R.; Peuker, C.; Pilz, W.; Storek, W. Synthesis and characterization of Ge-ZSM-5 zeolites. J. Phys. Chem. 1993, 97, 5678-5684. [CrossRef]

110. Kosslick, H.; Tuan, V.A.; Walther, G.; Storek, W. Study on the Isomorphous Substitution of Silicon by Indium in the MFI Framework. Cryst. Res. Technol. 1993, 28, 1109-1114. [CrossRef]

111. Liu, Y.; Zhang, Y.Y.; Yang, T.Y.; He, W.L. Study on the Calcination of Titanium Silicalite Zeolite (TS-1). Adv. Mater. Res. 2011, 287-290, 317-321. [CrossRef]

112. Viswanathan, B.; Pulikottil, A.C. Surface properties of ZSM-5 modified by phosphorus. Catal. Lett. 1993, 22, 373-379. [CrossRef]

113. Sadeghpour, P.; Haghighi, M.; Khaledi, K. High-temperature efficient isomorphous substitution of boron into ZSM-5 nanostructure for selective and stable production of ethylene and propylene from methanol. Mater. Chem. Phys. 2018, 217, 133-150. [CrossRef]

114. Bordiga, S.; Bonina, F.; Damin, A.; Lamberti, C. Reactivity of Ti(iv) species hosted in TS- 1 towards $\mathrm{H}_{2} \mathrm{O}_{2}-\mathrm{H}_{2} \mathrm{O}$ solutions investigated by ab initio cluster and periodic approaches combined with experimental XANES and EXAFS data: A review and new highlights. Phys. Chem. Chem. Phys. 2007, 9, 4854-4878. [CrossRef] [PubMed]

115. Thangaraj, A.; Kumar, R.; Mirajkar, S.P.; Ratnasamy, P. Catalytic properties of crystalline titanium silicalites I. Synthesis and characterization of titanium-rich zeolites with MFI structure. J. Catal. 1991, 130, 1-8. [CrossRef]

116. Fan, W.; Duan, R.-G.; Yokoi, T.; Wu, P.; Kubota, Y.; Tatsumi, T. Synthesis, Crystallization Mechanism, and Catalytic Properties of Titanium-Rich TS-1 Free of Extraframework Titanium Species. J. Am. Chem. Soc. 2008, 130, 10150-10164. [CrossRef]

117. Bellussi, G.; Millini, R. Background and Recent Advances in Ti-Containing Zeo-lite Materials. Struct. React. Metals Zeolite Mater. 2017, 178, 1-52.

118. Henry, P.F.; Weller, M.T.; Wilson, C.C. Structural Investigation of TS-1: Determination of the True Nonrandom Titanium Framework Substitution and Silicon Vacancy Distribution from Powder Neutron Diffraction Studies Using Isotopes. J. Phys. Chem. B 2001, 105, 7452-7458. [CrossRef]

119. Alvarado-Swaisgood, A.E.; Barr, M.K.; Hay, P.J.; Redondo, A. Ab initio quantum chemical calculations of aluminum substitution in zeolite ZSM-5. J. Phys. Chem. 1991, 95, 10031-10036. [CrossRef]

120. Redondo, A.; Hay, P.J. Quantum chemical studies of acid sites in zeolite ZSM-5. J. Phys. Chem. 1993, 97, 11754-11761. [CrossRef]

121. Sklenak, S.; Dědeček, J.; Li, C.; Wichterlová, B.; Gábová, V.; Sierka, M.; Sauer, J. Aluminium siting in the ZSM-5 framework by combination of high resolution 27Al NMR and DFT/MM calculations. Phys. Chem. Chem. Phys. 2009, 11, 1237-1247. [CrossRef]

122. Pashkova, V.; Sklenak, S.; Klein, P.; Urbanova, M.; Dědeček, J. Location of Framework Al Atoms in the Channels of ZSM-5: Effect of the (Hydrothermal) Synthesis. Chem. Eur. J. 2016, 22, 3937-3941. [CrossRef]

123. Dib, E.; Mineva, T.; Veron, E.; Sarou-Kanian, V.; Fayon, F.; Alonso, B. ZSM-5 Zeolite: Complete Al Bond Connectivity and Implications on Structure Formation from Solid-State NMR and Quantum Chemistry Calculations. J. Phys. Chem. Lett. 2017, 9, 19-24. [CrossRef]

124. Zhang, N.; Liu, C.; Ma, J.; Li, R.; Jiao, H. Determining the structures, acidity and adsorption properties of Al substituted HZSM-5. Phys. Chem. Chem. Phys. 2019, 21, 18758-18768. [CrossRef]

125. Mentzen, B.F. Localizing adsorption sites in zeolitic materials by X-ray powder diffraction: Pyridine sorbed in B.ZSM-5. J. Appl. Crystallogr. 1989, 22, 100-104. [CrossRef]

126. Vetrivel, R. Preferred sites for the isomoprhous substituted for boron in ZSM-5 zeolite structure. Zeolites 1992, 12, 424-427. [CrossRef]

127. Chatterjee, A.; Chandra, A.K. Fe and B substitution in ZSM-5 zeolites: A quantum-mechanical study. J. Mol. Catal. A Chem. 1997, 119, 51-56. [CrossRef]

128. Lermer, H.; Draeger, M.; Steffen, J.; Unger, K.K. Synthesis and structure refinement of ZSM-5 single crystals. Zeolites 1985, 5, 131-134. [CrossRef]

129. Chao, K.-J.; Lin, J.-C.; Wang, Y.; Lee, G.H. Single crystal structure refinement of TPA ZSM-5 zeolite. Zeolites 1986, 6, 35-38. [CrossRef]

130. Hoff, T.C.; Thilakaratne, R.; Gardner, D.W.; Brown, R.C.; Tessonnier, J.-P. Thermal Stability of Aluminum-Rich ZSM-5 Zeolites and Consequences on Aromatization Reactions. J. Phys. Chem. C 2016, 120, 20103-20113. [CrossRef]

131. Haag, W.O.; Dessau, R.M. Proceedings of 8th International Congress on Catalysis; Dechema: Frankfurt, Germany, 1984; Volume 2, p. 305.

132. Breck, D. Zeolite Molecular Sieves; Mir: Moscow, Russia, 1976; p. 781. (In Russian) 
133. Kul'pina, Y.N.; Prokof'iev, V.Y.; Gordina, N.E.; Khmylova, O.E.; Petukhova, N.V.; Gazakhova, S.I. Use of IR spectroscopy to study the structures of low modular zeolites. Izv. Vyss. Uchebnykh Zaved. Khimiya Khimicheskaya Tekhnol. 2017, 60, 44-50. [CrossRef]

134. Cadar, O.; Senila, M.; Hoaghia, M.-A.; Scurtu, D.; Miu, I. Effects of thermal treatment on natural clinoptilolite-rich zeolite behavior in simulated biological fluids. Levei Mol. 2020, 25, 2570. [CrossRef]

135. Jiang, N.; Shang, R.; Heijman, S.G.J.; Rietveld, L.C. High-silica zeolites for adsorption of organic micro-pollutants in water treatment: A review. Water Res. 2018, 144, 145-161. [CrossRef]

136. Bogdan, V.I.; Koklin, A.E.; Kazansky, V.B. Catalytic activity of H-forms of zeolites in the isomerization of supercritical N-pentane and their physicochemical properties. Kinet. Catal. 2010, 51, 762-768. [CrossRef]

137. Leon, A.; Ruequen, P.; Garin, C.; Segura, R.; Vargas, P.; Zapata, P.; Orihuela, P.A. FTIR and Raman Characterization of TiO 2 Nanoparticles Coated with Polyethylene Glycol as Carrier for 2-Methoxyestradiol. Appl. Sci. 2017, 7, 49. [CrossRef]

138. Bagnasco, G.; Ciambelli, P.; Corbo, P. DSC characterization of ZSM-5/MgO/ $\mathrm{Al}_{2} \mathrm{O}_{3}$ catalysts. J. Therm. Anal. 1985, 30, 1253-1257. [CrossRef]

139. Kasraian, K.; DeLuca, P.P. Thermal Analysis of the Tertiary Butyl Alcohol-Water System and Its Implications on Freeze-Drying. Pharm. Res. 1995, 12, 484-490. [CrossRef]

140. Dzhapparov, T.A.; Bazaev, A. Study of thermal stability of binary systems water-aliphatic alcohol. Bull. Kazan Technol. Univ. 2014, 17, 164-166. (In Russian)

141. Itzel-Hernandez, G.; Hernandez Miguel, A.; Portillo, R.; Petranovskiy, V.P.; Pestryakov, A.N.; Rubio, E. Hierarchical nanoporosity structure of Mexican natural clinoptilolite type. Bull. Tomsk Polytech. Univ. Eng. Georesour. 2018, 329, 107-117. (In Russian)

142. Wagner, C.D.; Naumkin, A.V.; Kraut-Vass, A.; Allison, J.W.; Powell, C.J.; Rumble, J.R. NIST XPS Database; Version 3.4; National Institute of Standards and Technology: Gaithersburg, MD, USA, 2003; p. 20899.

143. Mulakov, S.P.; Gotovtsev, P.M.; Gainanova, A.A.; Kravchenko, G.V.; Kuz'micheva, G.M.; Podbel'skii, V.V. Generation of the Reactive Oxygen Species on the surface of nanosized titanium(IV) oxides particles under UV-irradiation and their connection with photocatalytic properties. J. Photochem. Photobiol. A Chem. 2020, 393, 112424. [CrossRef]

144. Ting, F.; Gen, S.F.; Lei, Y.; Jia, H.P. One-Dimensional Nanostructured $\mathrm{TiO}_{2}$ for Photocatalytic Degradation of Organic Pollutants in Wastewater. Int. J. Photoenergy 2014, 2014, 1-14.

145. Savinov, E.N. Photocatalytic methods of water and air purification. Sorosovskij Educ. J. 2000, 6, 52-56.

146. Chen, F.; Zhao, J.; Hidaki, H. Highly selective deethylation of Rhodamine B: Adsorption and photooxidation pathways of the dye on the $\mathrm{TiO}_{2} / \mathrm{SiO}_{2}$ composite photocatalyst. Int. J. Photoenergy 2003, 5, 209-217. [CrossRef]

147. Gong, J.; Gao, X.; Li, M.; Nie, Q.; Pan, W.; Liu, R. Dye adsorption on electrochemical exfoliated graphen oxide nanosheets: pH influence, kinetics and equilibrium in aqueous solution. Int. J. Envinron. Sci. Tech. 2017, 14, 305-314. [CrossRef]

148. Domoroshchina, E.; Orekhov, A.; Chernyshev, V.; Kuz'micheva, G.; Kravchenko, G.; Klechkovskaya, V.; Pirutko, L. Relationship between Anatase/Mordenite nanocomposite (micro)structure and its functional (photocatalytic and adsorption) properties. Res. Chem. Intermed. 2019, 45, 2869-2885. [CrossRef]

149. Nosaka, Y.; Nosaka, A.Y. Generation and Detection of Reactive Oxygen Species in Photocatalysis. Chem. Rev. 2017, 117, 11302-11336. [CrossRef]

150. Vladimirov, Y.A. Activated chemiluminescence and bioluminescence as a tool in biomedical research. Sorosovskij Educ. J. Biol. 2001, 7, 16-23.

151. Blatun, L.A. Banezion ${ }^{\circledR}$ (powder, ointment)—Prospects for the use in complex surgical treatment of purulent-necrotic lesions of the lower extremities in patients with diabetic foot syndrome. Wounds 2015, 2, 36-44. (In Russian)

152. Savadyan, E.S.; Melnikova, V.M.; Belikova, G.P. Modern Trends in the Use of Argentic-Containing Antiseptics. Antibiot Khimioter 1989, 11, 874-878. (In Russian)

153. Alotibi, M.F.; Alshammari, B.A.; Alotaibi, M.H.; Alotaibi, F.M.; Alshihri, S.; Navarro, R.M.; Fierro, J.L.G. ZSM-5 Zeolite Based Additive in FCC Process: A Review on Modifications for Improving Propylene Production. Catal. Surv. Asia 2020, $24,1-10$. [CrossRef]

154. Biligetu, T.; Wang, Y.; Nishitoba, T.; Otomo, R.; Park, S.; Mochizuki, H.; Kondo, J.N.; Tatsumi, T.; Yokoi, T. Al distribution and catalytic performance of ZSM-5 zeolites synthesized with various alcohols. J. Catal. 2017, 353, 1-10. [CrossRef]

155. Chen, C.; Zhang, Q.; Meng, Z.; Li, C.; Shan, H. Effect of magnesium modification over H-ZSM-5 in methanol to propylene reaction. Appl. Petrochem. Res. 2015, 5, 277-284. [CrossRef]

156. Pilipenko, A.Y. Regularities of Ethanol Conversion on the Surface of High-Siliceous Zeolites of the ZSM-5 Type. Ph.D. Thesis, Saratov State University, Saratov, Russia, 2017. (In Russian).

157. Bonelli, B.; Cozzolino, M.; Tesser, R.; Serio, M.D.; Piumetti, M.; Garrone, E.; Santacesaria, E. Study of the surface acidity of $\mathrm{TiO}_{2} / \mathrm{SiO}_{2}$ catalysts by means of FTIR measurements of $\mathrm{CO}$ and $\mathrm{NH}_{3}$ adsorption. J. Catal. 2007, 246, 293-300. [CrossRef]

158. Noda, L.K.; de Almeida, R.M.; Gonçalves, N.S.; Probst, L.F.D.; Sala, O. $\mathrm{TiO}_{2}$ with a high sulfate content-Thermogravimetric analysis, determination of acid sites by infrared spectroscopy and catalytic activity. Catal. Today 2003, 85, 69-74. [CrossRef]

159. Li, F.-M.; Yang, H.-Q.; Ju, T.-Y.; Li, X.-Y.; Hu, C.-W. Activation of Propane C-H and C-C Bonds by Gas-Phase Pt Atom: A Theoretical Study. Int. J. Mol. Sci. 2012, 13, 9278-9297. [CrossRef]

160. Wolschlag, L.M.; Couch, K.A. UOP FCC Innovations Developed Using Sophisticated Engineering Tools. 2010. Available online: http: / / www.uop.com/?document=uop-fcc-innovation-tech-paper\&download=1 (accessed on 22 November 2021). 
161. Yakovleva, I.S.; Banzaraktsaeva, S.P.; Ovchinnikova, E.V.; Chumachenko, V.A.; Isupova, L.A. Catalytic Dehydration of Bioethanol to Ethylene. Review. Katal. Promyshlennosti 2016, 16, 57-73. [CrossRef]

162. Chaichana, E.; Boonsinvarothai, N.; Chitpong, N.; Jongsomjit, B. Catalytic dehydration of ethanol to ethylene and diethyl ether over alumina catalysts containing different phases with boron modification. J. Porous Mater. 2019, 26, 599-610. [CrossRef]

163. Millini, R.; Previde Massara, E.; Perego, G.; Bellussi, G. Framework Composition of Titanium Silicalite-1. J. Catal. 1992, 137, 497-503. [CrossRef]

164. Castro-Martins, S.; Tuel, A.; Taarit, Y.B. Characterization of Titanium Silicalites Using Cyclic Voltammetry. Stud. Surf. Sci. Catal. 1994, 84, 501-508.

165. Ricchiardi, G.; Damin, A.; Bordiga, S.; Lamberti, C.; Spano, G.; Rivetti, F.; Zecchina, A. Vibrational Structure of Titanium Silicate Catalysts. A Spectroscopic and Theoretical Study. J. Am. Chem. Soc. 2001, 123, 11409-11419. [CrossRef]

166. Sun, W.; Song, H.; Xi, Z.; Ma, J.; Wang, B.; Liu, X.; Chen, K. The synthesis and enhanced electrorheological properties of TS-1/titanium oxide core-shell nanocomposite. Ind. Eng. Chem. Res. 2020, 59, 1168-1182. [CrossRef]

167. Dingwell, D.B.; Paris, E.; Seifert, F.; Mottana, A.; Romano, C. X-ray absorption study of Ti-bearing silicate glasses. Phys. Chem. Miner. 1994, 21, 501-509. [CrossRef]

168. Farges, F.; Brown, G.E.; Rehr, J. Ti K-edge XANES studies of Ti coordination and disorder in oxide compounds: Comparison between theory and experiment. J. Phys. Rev. B Condens. Matter Mater. Phys. 1997, 56, 1809. [CrossRef]

169. Romano, C.; Paris, E.; Poe, B.T.; Giuli, G.; Dingwell, D.B.; Mottana, A. Effect of aluminum on Ti-coordination in silicate glasses: A XANES study. Am. Mineral. 2000, 85, 108-117. [CrossRef]

170. Zecchina, A.; Bordiga, S.; Spoto, G.; Damin, A.; Berlier, G.; Bonino, F.; Prestipino, C.; Lamberti, C. In Situ Characterization of Catalysts Active in Partial Oxidations: TS-1 and Fe-MFI Case Studies. Top. Catal. 2002, 21, 67-78. [CrossRef]

171. Lamberti, C.; Bordiga, S.; Arduino, D.; Zecchina, A. Evidence of the Presence of Two Different Framework Ti(IV) Species in Ti-Silicalite-1 in Vacuo Conditions: An EXAFS and a Photoluminescence Study. J. Phys. Chem. B 1998, 102, 6382-6390. [CrossRef]

172. Gallo, J.M.R.; Bueno, J.M.C.; Schuchardt, U. Catalytic Transformations of Ethanol for Biorefineries. J. Braz. Chem. Soc. 2014, 25, 2229-2243. [CrossRef] 